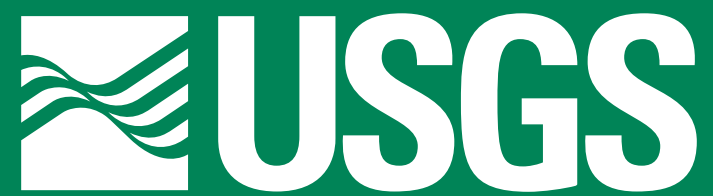

science for a changing world

\title{
Water-Quality Assessment of the Great Salt Lake Basins, Utah, Idaho, and Wyoming-Environmental Setting and Study Design
}

Water-Resources Investigations Report 02-4115

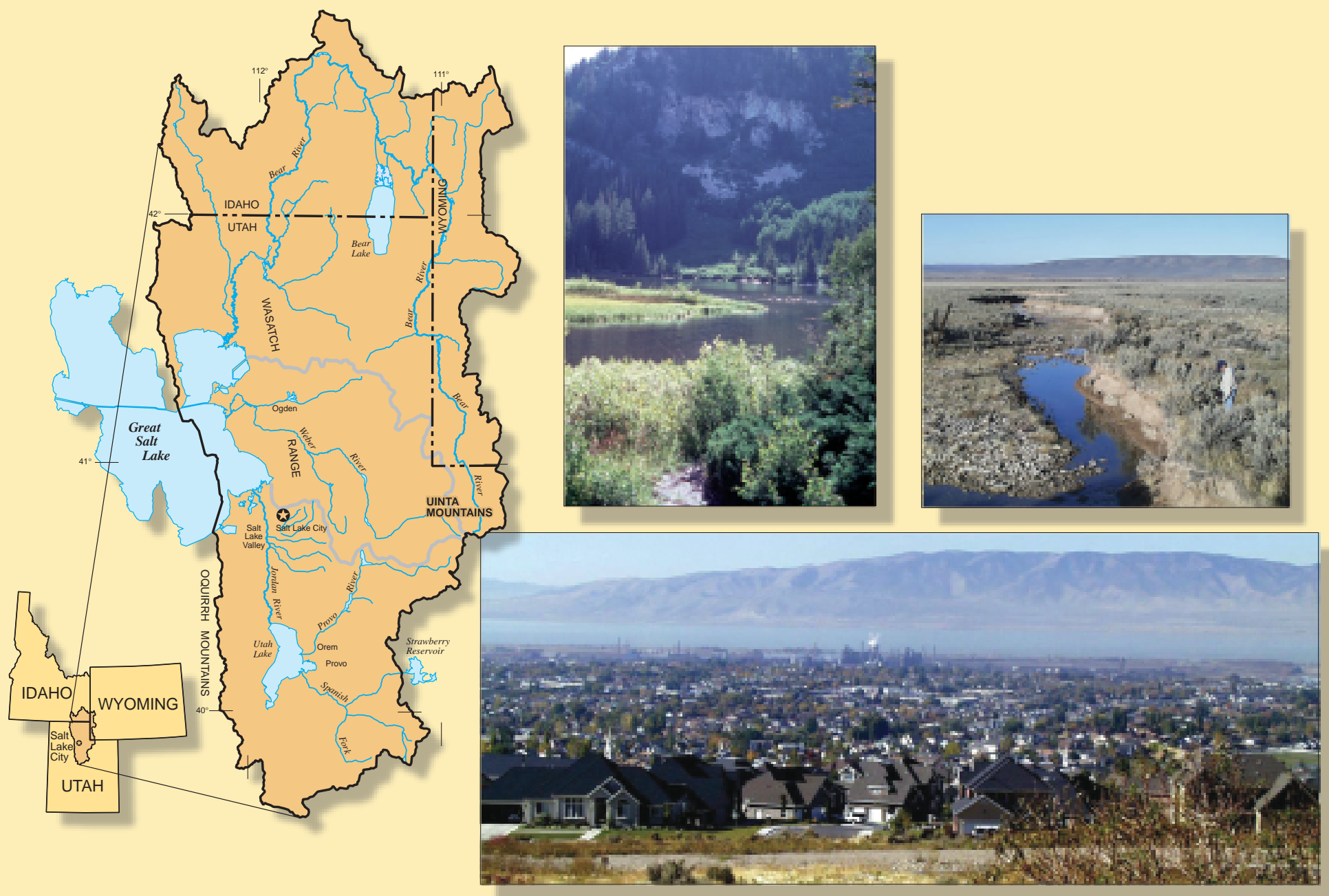

U.S. Department of the Interior

U.S. Geological Survey

National Water-Quality Assessment Program 


\section{Water-Quality Assessment of the Great Salt Lake Basins, Utah, Idaho, and Wyoming- Environmental Setting and Study Design}

By Robert L. Baskin, Kidd M. Waddell, Susan A. Thiros, Elise M. Giddings, Heidi K. Hadley, Doyle W. Stephens, and Steven J. Gerner

\section{U.S. GEOLOGICAL SURVEY}

Water-Resources Investigations Report 02-4115

NATIONAL WATER-QUALITY ASSESSMENT PROGRAM 


\title{
U.S. DEPARTMENT OF THE INTERIOR GALE A. NORTON, Secretary
}

\author{
U.S. GEOLOGICAL SURVEY
}

Charles G. Groat, Director

Any use of trade, product, or firm names in this publication is for descriptive purposes only and does not imply endorsement by the U.S. Government.

For additional information write to:

District Chief

U.S. Geological Survey 2329 West Orton Circle

Salt Lake City, Utah 84119

http://ut.water.usgs.gov
Copies of this report can be purchased from:

U.S. Geological Survey

Branch of Information Services

Building 810

Box 25286, Federal Center

Denver, CO 80225-0286 


\section{FOREWORD}

The U.S. Geological Survey (USGS) is committed to serve the Nation with accurate and timely scientific information that helps enhance and protect the overall quality of life, and facilitates effective management of water, biological, energy, and mineral resources (http://www.usgs.gov/). Information on the quality of the Nation's water resources is of critical interest to the USGS because it is so integrally linked to the long-term availability of water that is clean and safe for drinking and recreation and that is suitable for industry, irrigation, and habitat for fish and wildlife. Escalating population growth and increasing demands for the multiple water uses make water availability, now measured in terms of quantity and quality, even more critical to the long-term sustainability of our communities and ecosystems.

The USGS implemented the National Water-Quality Assessment (NAWQA) program to support national, regional, and local information needs and decisions related to water-quality management and policy (http://water.usgs.gov/nawqa). Shaped by and coordinated with ongoing efforts of other Federal, State, and local agencies, the NAWQA program is designed to answer: What is the condition of our Nation's streams and ground water? How are the conditions changing over time? How do natural features and human activities affect the quality of streams and ground water, and where are those effects most pronounced? By combining information on water chemistry, physical characteristics, stream habitat, and aquatic life, the NAWQA program aims to provide sciencebased insights for current and emerging water issues and priorities. NAWQA results can contribute to informed decisions that result in practical and effective water-resource management and strategies that protect and restore water quality.

Since 1991, the NAWQA program has implemented interdisciplinary assessments in more than 50 of the Nation's most important river basins and aquifers, referred to as Study Units (http://water.usgs.gov/nawqa/ nawqamap.html). Collectively, these Study Units account for more than 60 percent of the overall water use and population served by public water supply, and are representative of the Nation's major hydrologic landscapes, priority ecological resources, and agricultural, urban, and natural sources of contamination.

Each assessment is guided by a nationally consistent study design and methods of sampling and analysis. The assessments thereby build local knowledge about water-quality issues and trends in a particular stream or aquifer while providing an understanding of how and why water quality varies regionally and nationally. The consistent, multi-scale approach helps to determine if certain types of water-quality issues are isolated or pervasive, and allows direct comparisons of how human activities and natural processes affect water quality and ecological health in the Nation's diverse geographic and environmental settings. Comprehensive assessments on pesticides, nutrients, volatile organic compounds, trace metals, and aquatic ecology are developed at the national scale through comparative analysis of the Study-Unit findings (http://water.usgs.gov/nawqa/natsyn.html).

The USGS places high value on the communication and dissemination of credible, timely, and relevant science so that the most recent and available knowledge about water resources can be applied in management and policy decisions. We hope this NAWQA publication will provide you the needed insights and information to meet your needs, and thereby foster increased awareness and involvement in the protection and restoration of our Nation's waters.

The NAWQA program recognizes that a national assessment by a single program cannot address all waterresource issues of interest. External coordination at all levels is critical for a fully integrated understanding of watersheds and for cost-effective management, regulation, and conservation of our Nation's water resources. The program, therefore, depends extensively on the advice, cooperation, and information from other Federal, State, interstate, Tribal, and local agencies, non-government organizations, industry, academia, and other stakeholder groups. The assistance and suggestions of all are greatly appreciated.

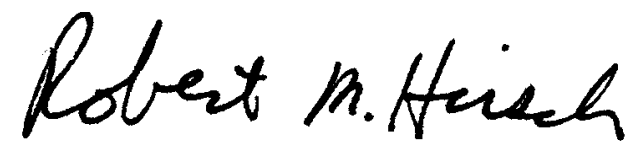

Robert M. Hirsch

Associate Director for Water 


\section{CONTENTS}

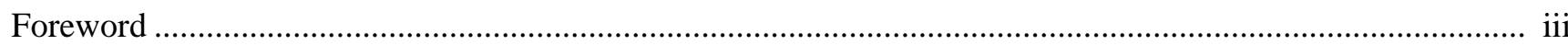

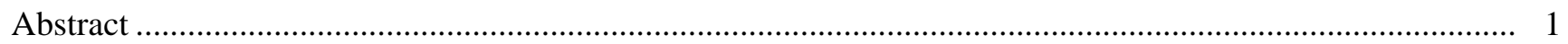

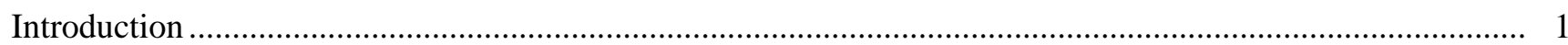

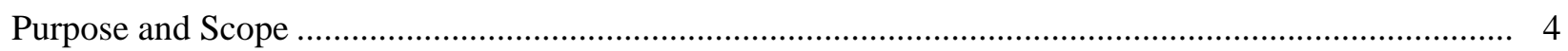

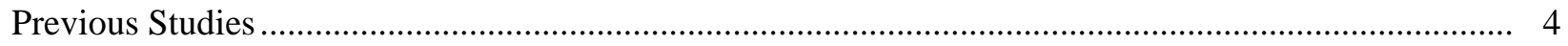

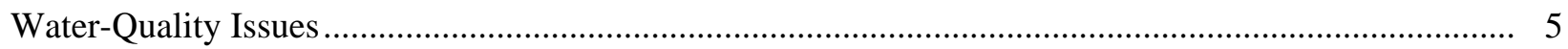

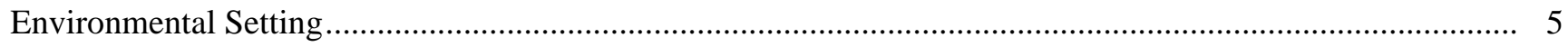

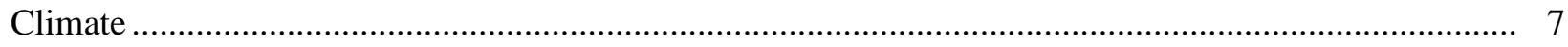

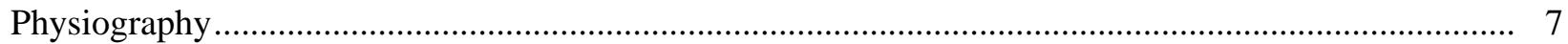

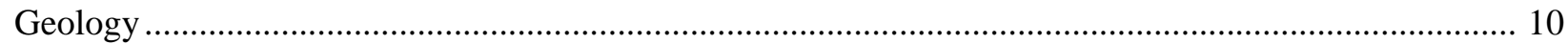

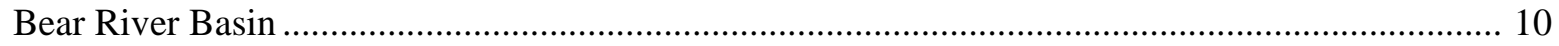

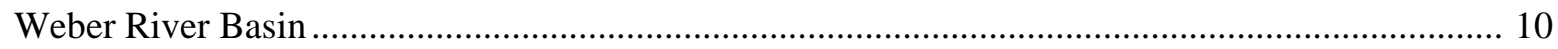

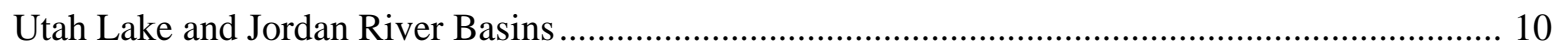

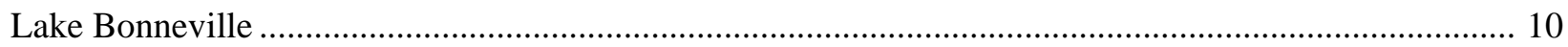

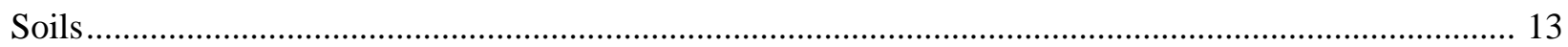

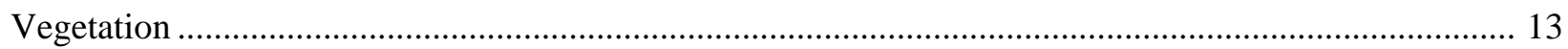

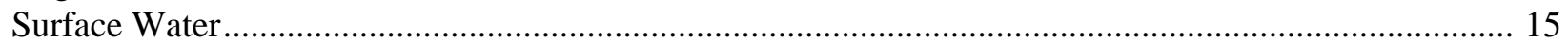

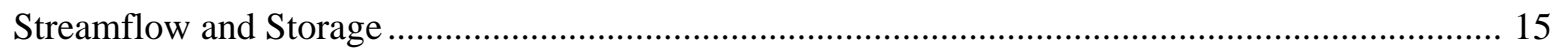

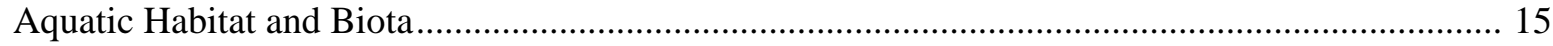

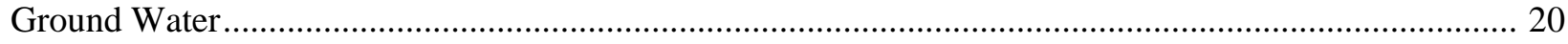

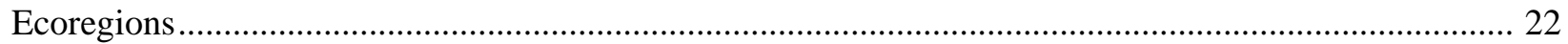

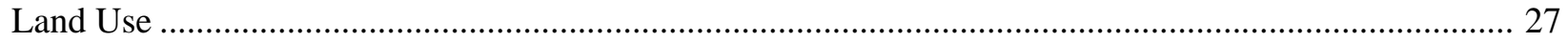

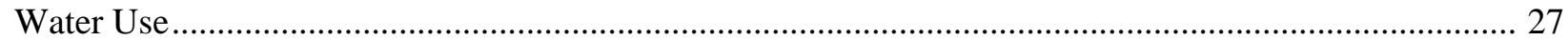

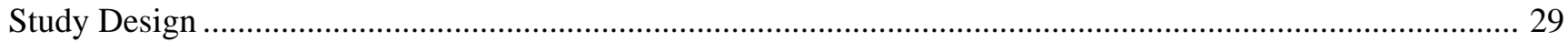

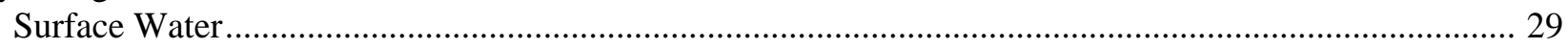

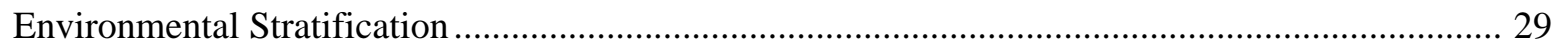

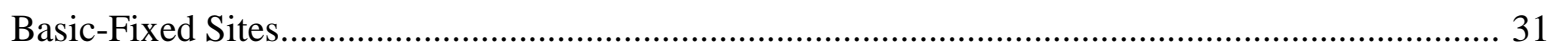

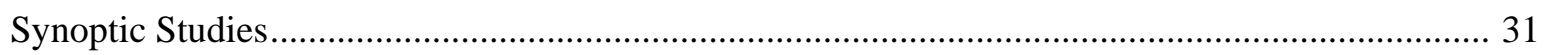

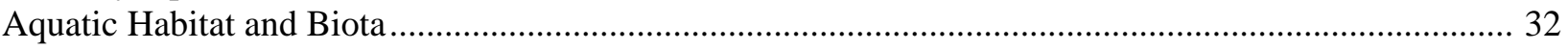

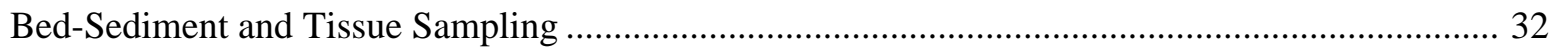

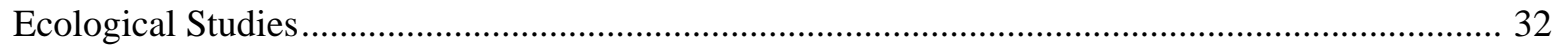

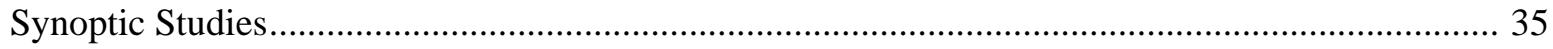

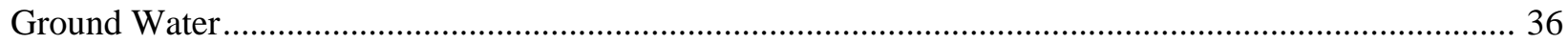

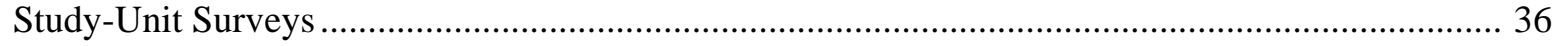

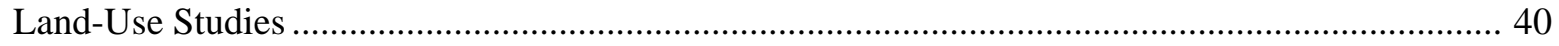

Shallow Ground-Water/Urban Land-Use Study ............................................................................. 40

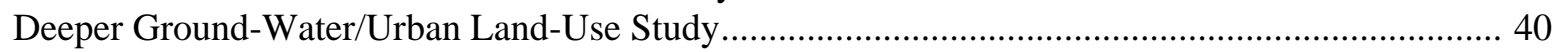

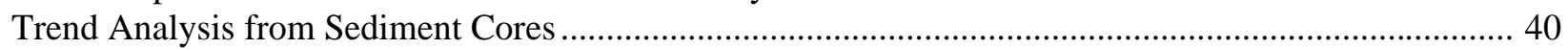

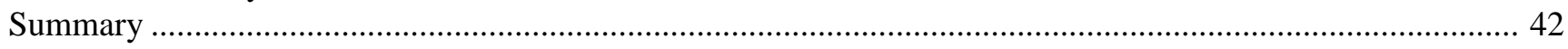

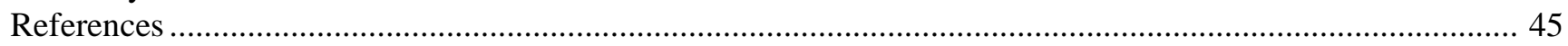




\section{FIGURES}

Figure 1. Map showing location of the Great Salt Lake Basins study unit, Utah, Idaho, and Wyoming. ....... 2

Figure 2. Map showing population density for the Great Salt Lake Basins study unit, 1990....................... 3

Figure 3. Graph showing projected population growth for Salt Lake County, Utah. ................................. 4

Figure 4. Graphs showing source and cause of stream water-quality impairment for the major river basins of the Great Salt Lake Basins study unit............................................................................... 6

Figure 5. Map showing average annual precipitation of the Great Salt Lake Basins study unit, 1961-90...... 8

Figure 6. Map showing physiographic provinces of the Great Salt Lake Basins study unit.......................... 9

Figure 7. Map showing surficial lithology of the Great Salt Lake Basins study unit. .................................. 11

Figure 8. Map showing approximate extent of Pleistocene-age Lake Bonneville, Utah, Idaho, and Nevada. . 12

Figure 9. Map showing generalized soil-drainage characteristics of the Great Salt Lake Basins study unit.... 14

Figure 10. Map showing estimated annual discharge for streams in the Great Salt Lake Basins study unit...... 16

Figure 11. Graphs showing seasonal variations in streamflow at selected sites in the Great Salt Lake Basins study unit.

Figure 12. Generalized block diagram showing the basin-fill deposits and ground-water flow system in Salt Lake Valley, Utah.

Figure 13. Map showing ground-water recharge and discharge areas in the Great Salt Lake Basins study unit

Figure 14. Chemical composition of selected ground-water samples from the principal basin-fill aquifer in

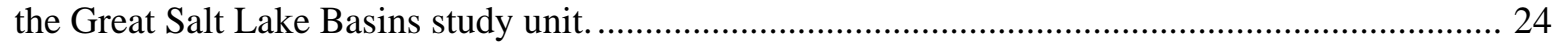

Figure 15. Map showing ecoregions of the Great Salt Lake Basins study unit. ............................................ 26

Figure 16. Map showing generalized land use in the Great Salt Lake Basins study unit, GIRAS level I......... 28

Figure 17. Percentage of total water use in the Great Salt Lake Basins study unit........................................ 30

Figure 18. Timeline of National Water-Quality Assessment program activities.......................................... 31

Figure 19. Chart showing occurrence and distribution assessment components for the first cycle of National Water-Quality Assessment program study units.

Figure 20. Chart showing environmental stratification for surface-water activities, Great Salt Lake Basins study unit.

Figure 21. Map showing location of basic-fixed surface-water monitoring sites for the Great Salt Lake Basins study unit.

Figure 22. Map showing location of bed-sediment, fish-tissue, and ecological sampling sites in the Great Salt Lake Basins study unit, 1999-2001.

Figure 23. Chart showing conceptual ground-water stratification for the Great Salt Lake Basins study unit.... 39

Figure 24. Map showing areas of recent residential/commerical development and ground-water recharge in Salt Lake Valley, Utah.

Figure 25. Map showing sites where sediment cores were collected for trend analysis during 1998, Utah and Idaho. 


\section{TABLES}

Table 1. Fish species in the Great Salt Lake Basins study unit ............................................................ 19

Table 2. Water use in the Great Salt Lake Basins study unit, 1995 ........................................................ 29

Table 3. Population served by public-supply water and self-supply water, Great Salt Lake Basins study

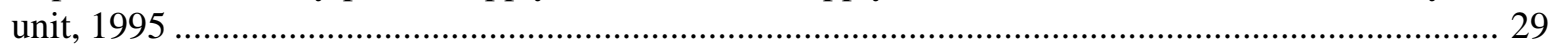

Table 4. Description of basic-fixed surface-water monitoring sites for streams in the Great Salt Lake

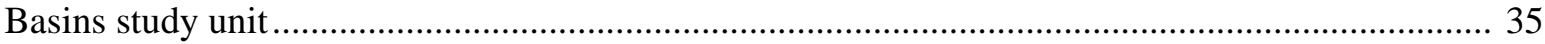

Table 5. Sites selected for occurrence survey to identify contaminants in bed sediment and fish tissue, and subset of sites for special sampling to determine presence of endocrine disrupters in fish tissue, Great Salt Lake Basins study unit

Table 6. Sites selected for ecological sampling and predominant habitat type expected at each site in the Great Salt Lake Basins study unit 
CONVERSION FACTORS AND VERTICAL DATUM

\begin{tabular}{|c|c|c|}
\hline Multiply & By & To obtain \\
\hline acre & 4,047 & square meter $\left(\mathrm{m}^{2}\right)$ \\
\hline acre-feet (acre-ft) & 1,233 & cubic meter $\left(\mathrm{m}^{3}\right)$ \\
\hline acre-foot per year (acre-ft/yr) & 1,233 & cubic meter $\left(\mathrm{m}^{3}\right)$ per year \\
\hline foot $(\mathrm{ft})$ & 0.3048 & meter $(\mathrm{m})$ \\
\hline cubic foot per second $\left(\mathrm{ft}^{3} / \mathrm{s}\right)$ & 0.02832 & cubic meter per second $\left(\mathrm{m}^{3} / \mathrm{s}\right)$ \\
\hline inch (in.) & 25.4 & millimeter $(\mathrm{mm})$ \\
\hline million gallons per day (Mgal/d) & 0.04381 & cubic meter per second $\left(\mathrm{m}^{3} / \mathrm{s}\right)$ \\
\hline mile (mi) & 1.609 & kilometer $(\mathrm{km})$ \\
\hline square mile $\left(\mathrm{mi}^{2}\right)$ & 2.590 & square kilometer $\left(\mathrm{km}^{2}\right)$ \\
\hline
\end{tabular}

In this report, air temperature is reported in degrees Fahrenheit $\left({ }^{\circ} \mathrm{F}\right)$, which may be converted to degrees Celsius $\left({ }^{\circ} \mathrm{C}\right)$ by the following equation:

$$
{ }^{\circ} \mathrm{F}=1.8\left({ }^{\circ} \mathrm{C}\right)+32
$$

Sea level: In this report "sea level" refers to the National Geodetic Vertical Datum of 1929-a geodetic datum derived from a general adjustment of the first-order level nets of the United States and Canada, formerly called Sea Level Datum of 1929. 


\title{
Water-Quality Assessment of the Great Salt Lake Basins, Utah, Idaho, and Wyoming-Environmental Setting and Study Design
}

\author{
By Robert L. Baskin, Kidd M. Waddell, Susan A. Thiros, Elise M. Giddings, Heidi K. Hadley, \\ Doyle W. Stephens, and Steven J. Gerner
}

\section{ABSTRACT}

The Great Salt Lake Basins, Utah, Idaho, and Wyoming is 1 of 51 study units in the United States where the status and trends of water quality, and the factors controlling water quality, are being studied by the National Water-Quality Assessment program of the U.S. Geological Survey. The 14,500-square-mile Great Salt Lake Basins study unit encompasses three major river systems that enter Great Salt Lake: the Bear, the Weber, and the Utah Lake/Jordan River systems. The environmental setting of the study unit includes natural and human-related factors that potentially influence the physical, chemical, and/or biological quality of the surface- and ground-water resources. Surface- and ground-water components of the planned assessment activities are designed to evaluate the sources of natural and human-related factors that affect the water quality in the Great Salt Lake Basins study unit.

\section{INTRODUCTION}

The Great Salt Lake Basins is 1 of 51 study units to be investigated under the U.S. Geological Survey's National Water-Quality (NAWQA) program. The longterm goals of the NAWQA program are to describe the status and trends in the quality of a large representative part of the Nation's surface- and ground-water resources and to provide a sound, scientific understanding of the major natural and human factors that affect the quality of these resources (Leahy and others, 1990). The NAWQA program is designed to address water-quality issues at multiple scales with study units being the principal building blocks of the Program. The results of the study-unit investigations will provide information to help understand and manage the water resources of the study unit and will be aggregated with equivalent information from other study units to assess regional and national-scale waterquality issues.

The Great Salt Lake Basins study unit encompasses three major river systems that enter Great Salt Lake: the Bear, the Weber, and the Utah Lake/Jordan River systems (fig. 1). The headwaters of the Bear, the Weber, and the Provo (part of the Utah Lake river system) Rivers originate at the western part of the Uinta Mountains, at the east edge of the study unit. The streams flow through the wide valleys east of the Wasatch Range, emerge through the mountain ranges to the west, and discharge into Great Salt Lake. The Utah Lake/Jordan River system includes the Provo River and the Spanish Fork River which terminate in Utah Lake, and the Jordan River drainage. The Jordan River starts at the outflow from Utah Lake and flows northward through the Salt Lake Valley metropolitan area before discharging into Great Salt Lake.

Much of the $14,500 \mathrm{mi}^{2}$ of the Great Salt Lake Basins study unit is in Utah, but it also includes areas in Idaho and Wyoming. About 1.4 million people or 85 percent of the population of the State of Utah live along the western flanks of the Wasatch Range (fig. 2), where Utah's three largest cities (the Salt Lake City metropolitan area, Ogden, and Provo) are located. The population is expected to increase nearly 50 percent in the next 20 years with most of the increase occurring along the Wasatch Front from Provo to Ogden, Utah (fig. 3) (Utah Governor's Office of Planning and Budget, 1992). 


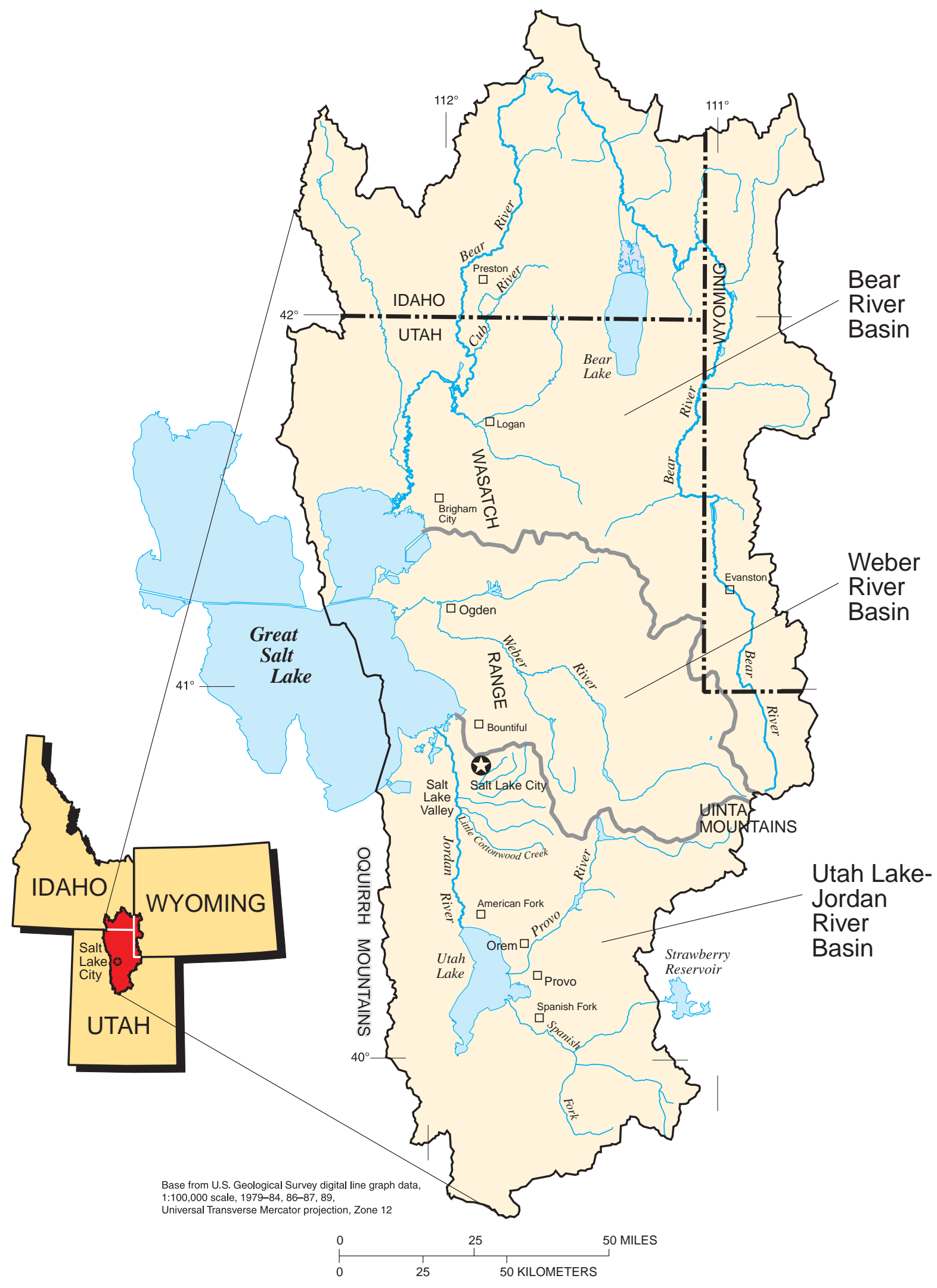

Figure 1. Location of the Great Salt Lake Basins study unit, Utah, Idaho, and Wyoming. 


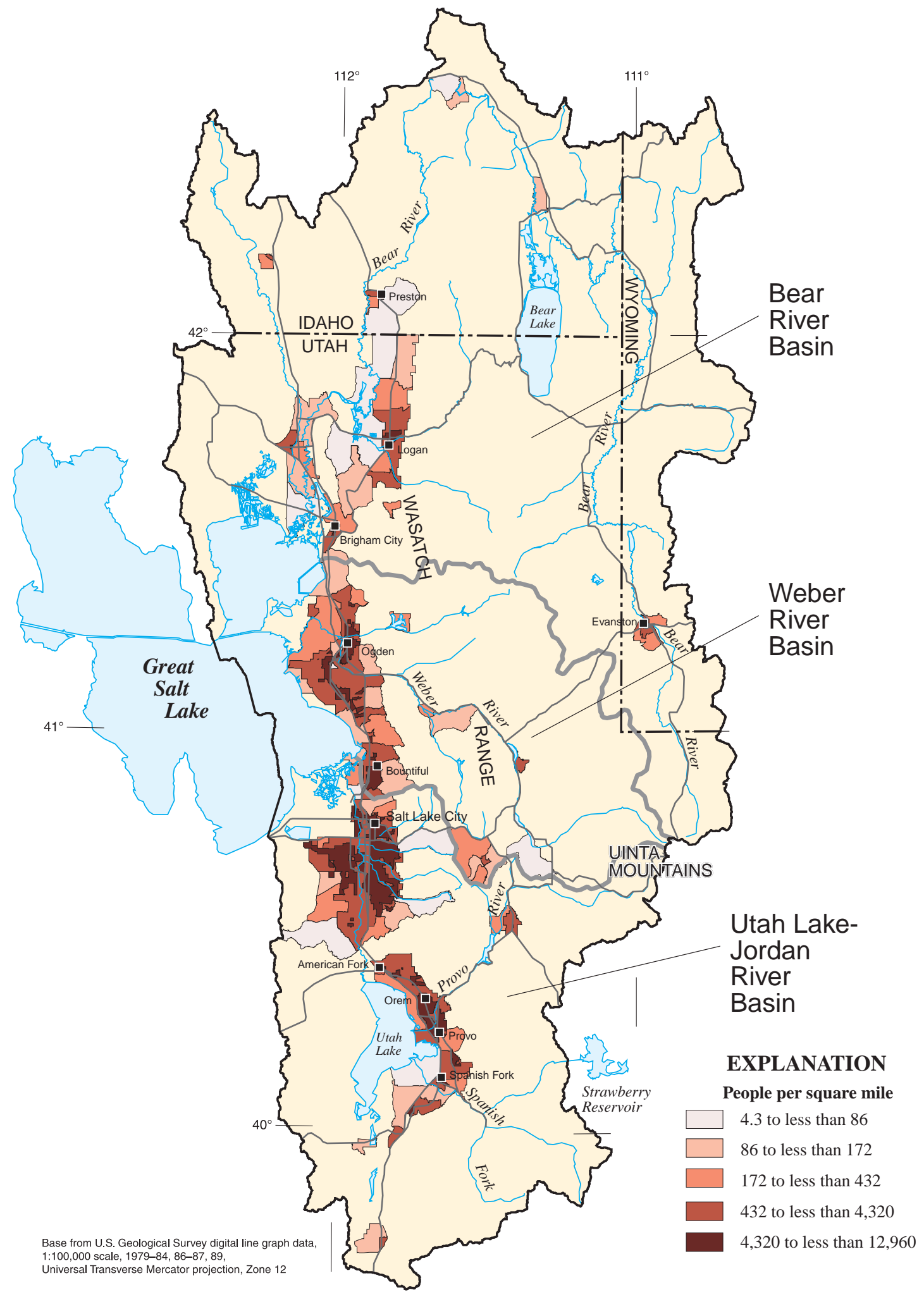

Figure 2. Population density for the Great Salt Lake Basins study unit, 1990.

Data from Hitt, 1994b. 


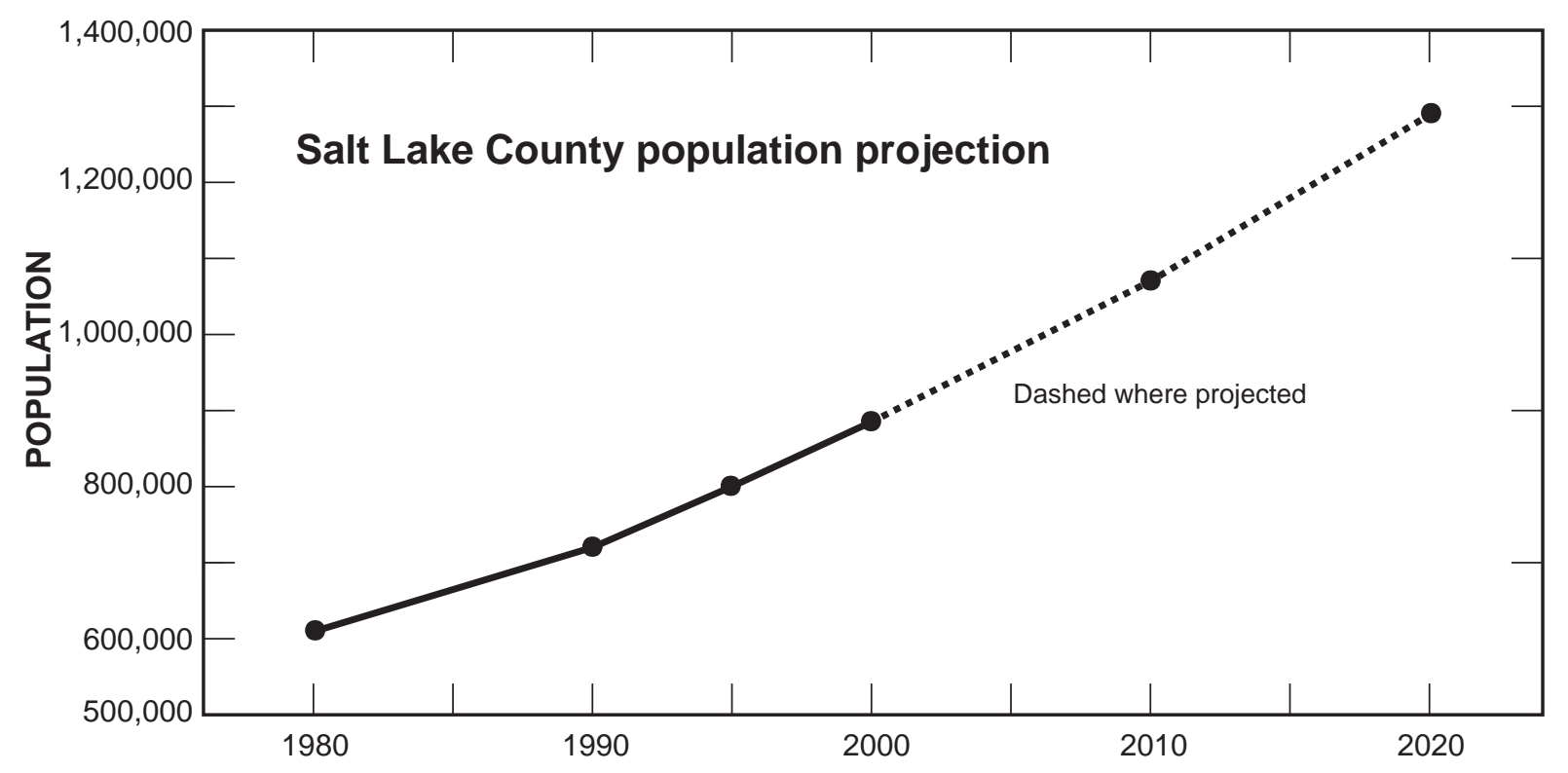

Figure 3. Projected population growth for Salt Lake County, Utah. Data from Utah Governor's Office of Planning and Budget, 1999.

\section{Purpose and Scope}

This report describes the natural and human factors that may affect or have a large-scale or regional influence on the surface-water and ground-water quality of the Great Salt Lake Basins (GRSL) study unit and the preliminary study design for data collection for the GRSL study unit. The environmental setting of the study unit was used as the first step in designing a multidisciplinary water-quality assessment of the basins. Baseline information contained in this report will be incorporated into future data analyses and referenced in future reports that address specific water-quality issues of the study unit and will be integrated into national or regional water-quality assessments.

The natural factors of physiography, geology, soils, climate, and hydrology largely determine the natural background quality of water; and the cultural factors of population, land and water use, and wastemanagement practices define the human influence on water quality. This report summarizes selected studies and provides an overview of existing water-quality conditions in the GRSL study unit.

\section{Previous Studies}

The description of the environmental setting is based on a review of currently available information, reports, and data from Federal, State, and local agencies. Much of this information was derived from U.S. Geological Survey (USGS) reports and maps and from the Utah Department of Natural Resources Water Plans for the Bear River (1992), Weber River (1997c), Jordan River (1997a), and Utah Lake (1997b) drainage basins. Map information was derived primarily from digital data from the USGS, U.S. Department of Agriculture National Resources Conservation Service (formerly Soil Conservation Service), U.S. Bureau of the Census, and the National Weather Service.

Ground water in the GRSL study area has had considerable study during the past several decades. Many of the interpretative studies have been done by the USGS in cooperation with the State of Utah. Many of the studies during the past 20 years have included digital models of the ground-water flow systems. The ground-water system in Cache Valley was described by Bjorklund and McGreevy (1971) and Kariya, Roark, and Hanson (1994); the lower Bear River area by Bjorklund and McGreevy (1974); the East Shore area of Great Salt Lake by Bolke and Waddell (1972) and Clark and others (1990); Salt Lake Valley by Hely, 
Mower, and Harr (1971), Waddell and others (1987a and 1987b), Thiros (1995), and Lambert (1995); northern Utah Valley by Cordova and Subitzky (1965) and Clark and Appel (1985); and southern Utah Valley by Cordova (1970) and Brooks and Stolp (1995). In addition to the interpretative studies for specific valleys and areas, a ground-water monitoring program has been conducted by the USGS in cooperation with the Utah Division of Water Rights and Division of Water Resources since 1964. The 38th in a series of annual reports that describe ground-water conditions in Utah was published in 2001 (Burden and others). The monitoring program includes annual measurement of water level and well discharge and collection of selected water-quality data within the major groundwater basins.

\section{Water-Quality Issues}

Point and nonpoint sources of contaminants, including leachates from mining and mill tailings, urban activities, industrial activities, and wastewater from storm sewers and treatment plants, have had detrimental effects on the quality of ground- and surface-water resources throughout the study area. Nonpoint sources of contaminants are the major impediments to use of streams and lakes in the GRSL study unit. Excessive nutrient levels have caused eutrophication in Utah Lake in the NAWQA study unit (Utah Department of Natural Resources, 1997b). The major contaminants that affect the use of streams by aquatic life are suspended sediments, nutrients, and metals (fig. 4). The major contaminant that affects the use of streams for agriculture is dissolved solids.

The GRSL NAWQA study unit has established a liaison committee composed of Federal, State, interstate, and local agencies, nongovernment organizations, industry, academia, and other stakeholder groups to assist and advise the study unit on local issues concerning water quality. The liaison committee has identified the major water-quality issues of concern in the study unit. Those issues include:

1. Nutrient releases into streams and ground water from point sources;

2. Erosion of sediment from stream banks as a result of fluctuating streamflow downstream from hydroelectric plants, modification of land cover or native vegetation, and hydrologic changes that have resulted from development, urbanization, and stream course modification;

3. Contamination from industrial and urban land use in ground-water recharge areas along the Wasatch Front;

4. Bacterial contamination from grazing, feedlots, and wastewater treatment plants;

5. Effects of contaminants (including saltwater) on wetlands and sensitive species;

6. Transport and fate of contaminants in or attached to suspended sediment in streams and rivers; and

7. Leachate from mine and uranium tailings and waste from metal refineries in the highly urbanized areas of the Wasatch Front.

\section{ENVIRONMENTAL SETTING}

The GRSL study unit includes an area of diverse topography, geomorphology, natural vegetation, geology, land use, and climate. Types of vegetation range from barren mud flats and desert shrubs near the shore of Great Salt Lake at an altitude of about 4,200 ft, to conifer forests in the Wasatch Range and Uinta Mountains above about $8,000 \mathrm{ft}$, to areas above the timberline at 10,000 to $12,000 \mathrm{ft}$. The headwaters of the Bear, Weber, and Provo Rivers originate at the western end of the Uinta Mountains, along the eastern edge of the study unit, at altitudes above $10,000 \mathrm{ft}$. The streams flow from their headwaters in the Uinta Mountains, join and flow through broad valleys, and emerge from the western side of the Wasatch Range (fig. 1). The Bear and Weber Rivers discharge into Great Salt Lake; the Provo River discharges into Utah Lake. The Jordan River begins at the northern end of Utah Lake, flows north through Salt Lake Valley, and discharges into Great Salt Lake.

As the streams emerge from the headwater areas and flow through the broad valleys east of the Wasatch Range, the natural effect on water quality generally is similar among the three rivers. In the lower altitudes west of the Wasatch Range and, in lesser part, the areas east of and adjacent to the Wasatch Range, both human and natural factors differ considerably and affect the streams in different ways. The Bear and Weber Rivers primarily are affected by agriculture, including livestock; the Jordan River primarily is affected by urban and industrial land use in the metropolitan area of the Salt Lake Valley. 
Source of stream water-quality impairment

\section{Bear River Basin}
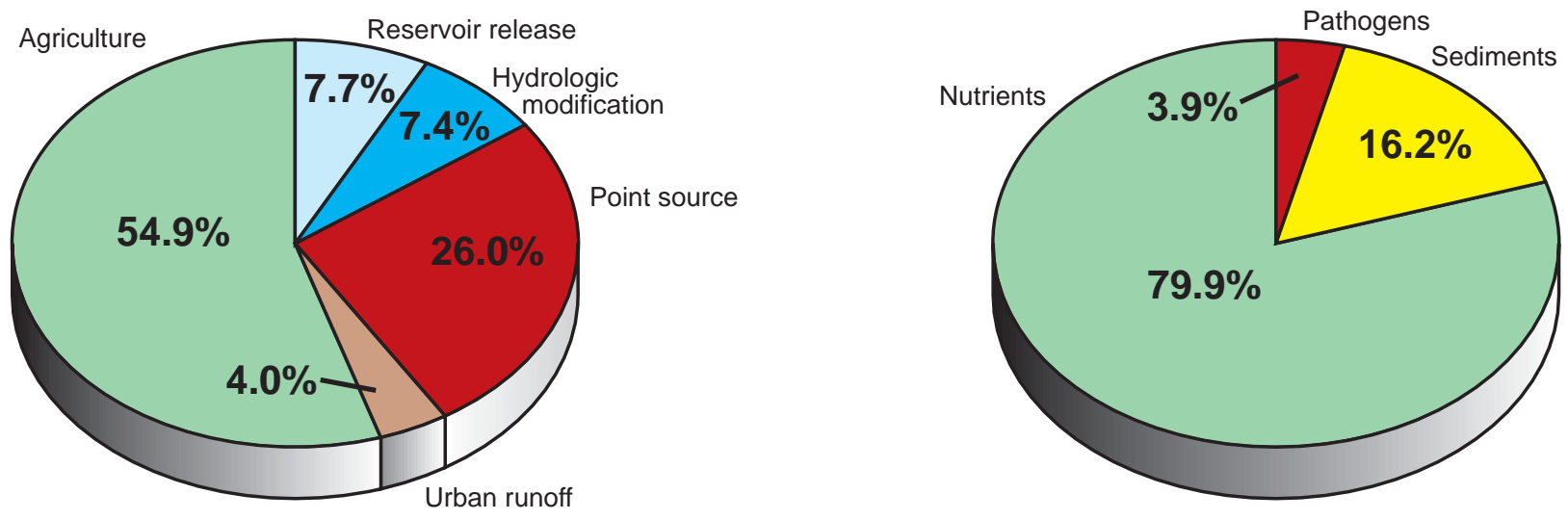

\section{Weber River Basin}
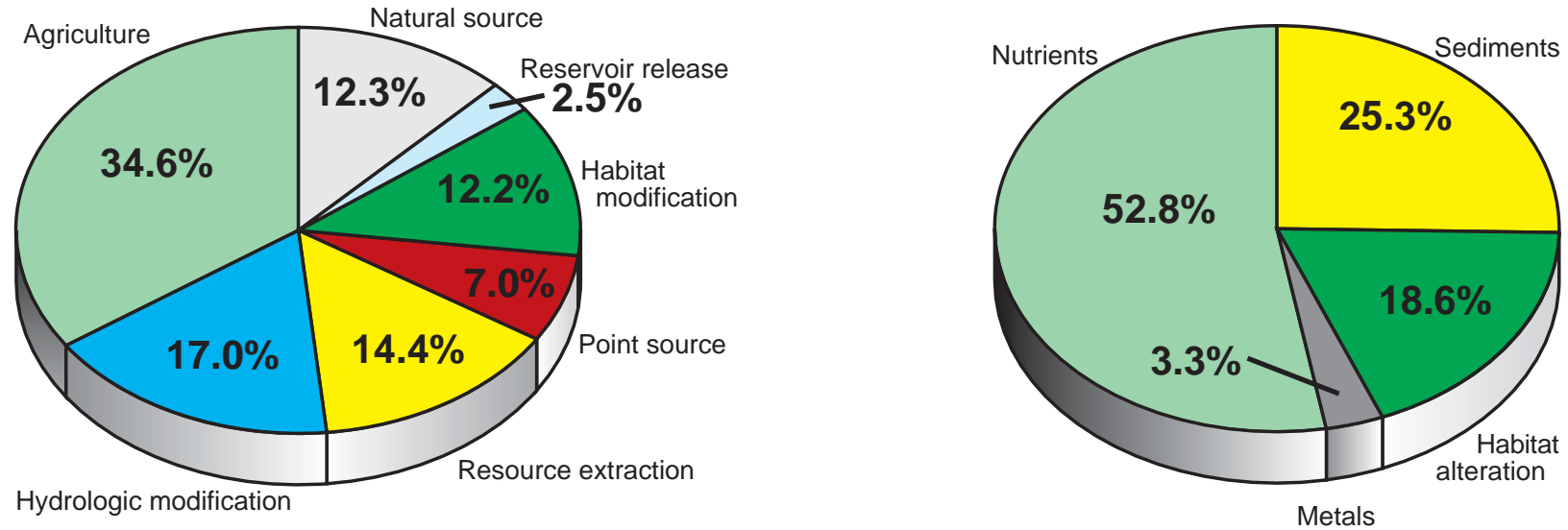

Hydrologic modification

\section{Utah Lake-Jordan River Basin}

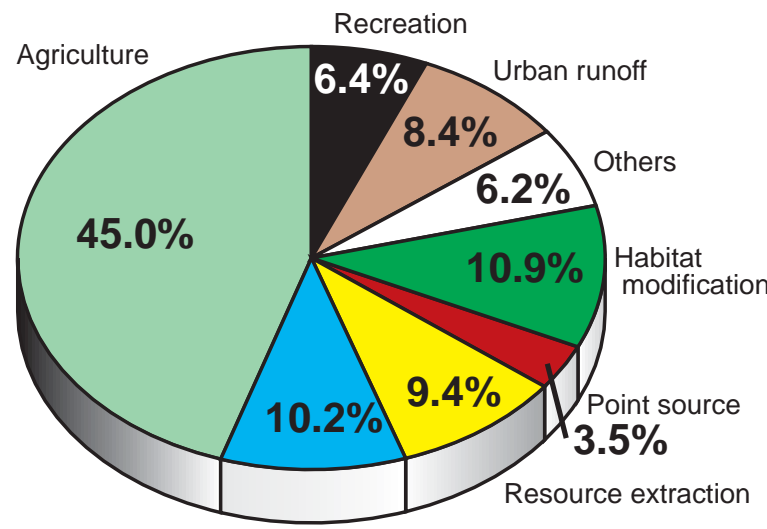

Hydrologic modification

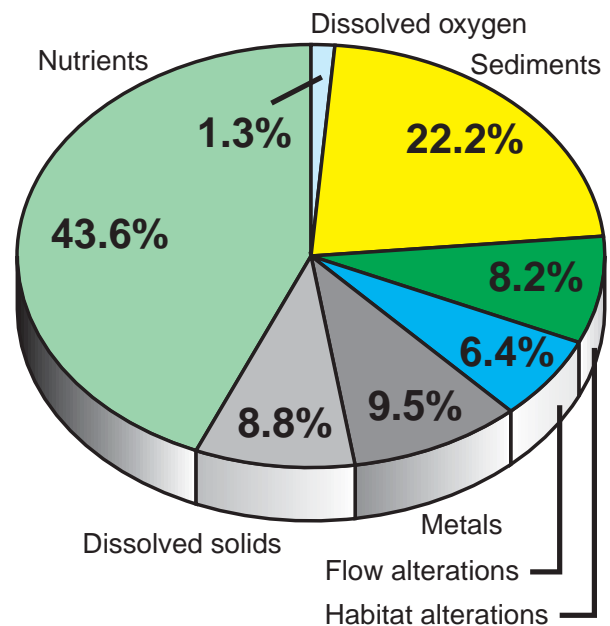

Figure 4. Source and cause of stream water-quality impairment for the major river basins of the Great Salt Lake Basins study unit.

Data from Utah Department of Natural Resources, 1996. 
Water can be contaminated by both natural and anthropogenic causes. Natural causes include modification of stream courses and streamflow by flooding, which results in increased erosion or an influx of storm-released natural contaminants, inflow of ground water containing high concentrations of dissolved solids into surface water, and waste materials from non-domesticated animals. Anthropogenic contamination includes a wide variety of point and nonpoint sources. Point sources are from specific, definable sources such as wastewater treatment plants, storm drains, and industrial effluent. Nonpoint sources are diffuse sources such as runoff from agriculture, mining, construction, urban and recreational areas, or through increased erosion through modification of the natural hydrologic regime.

Natural variations in ground-water quality primarily are controlled by water-rock interaction. The type of rock and residence time of water largely determine the inorganic chemical composition of ground water. Anthropogenic contamination commonly results from surface and subsurface land uses such as solid landfill wastes, mine tailings, in-situ mine workings, and subsurface injections of waste fluid. Potential contaminants applied to the land surface include fertilizers and pesticides applied to agricultural crops and lawns and gardens, herbicides used in residential and commercial applications, "natural" contaminants used by man such as road salts, waste materials generated by day-to-day activities such as sewage waste and derivatives from automobile use, and the dumping of waste material (oil, cleaning solvents, etc.) on the landscape. The natural and human factors that affect the water quality of the GRSL study unit are defined as the environmental setting and are examined in more detail in the following sections.

\section{Climate}

The climate in the GRSL study unit is typical of mountainous areas in the Western United States. Temperature generally fluctuates widely between summer and winter and between day and night. The high mountains have long, cold winters and short, cool summers. The lower valleys are more moderate, with less variance between maximum and minimum temperatures. Average annual temperature ranges from 32 to $52^{\circ} \mathrm{F}$. Average monthly maximum temperature reaches $92^{\circ} \mathrm{F}$ in July at the Salt Lake City International
Airport, and the average monthly minimum reaches $-1.5^{\circ} \mathrm{F}$ in January at Sage, Wyoming (U.S. Department of Commerce, 1992).

Each of the basins in the study unit receives most of its precipitation as snow during the winter months and produces most of its annual runoff during the spring as snowmelt. Average annual precipitation ranges from less than 10 to $16 \mathrm{in}$. on the valley floors to greater than $70 \mathrm{in.}$ in the high mountain areas (fig. 5).

Most of the precipitation in the mountainous part of the GRSL study unit occurs during the cold months as snow and originates in storms that move eastward across the continent from the North Pacific Ocean. As the masses of moist air move up the western slopes of mountain ranges, precipitation tends to increase; and as they move down the eastern slopes, precipitation decreases. Snowmelt during the spring and summer produces abundant flow in several streams draining the Wasatch Range but a very small volume of flow in streams draining the eastern side of the Oquirrh Mountains. Large volumes of snowmelt infiltrate the fractured bedrock of the Wasatch Range and provide recharge to the adjacent alluvial aquifers.

\section{Physiography}

The GRSL study unit includes parts of three major physiographic provinces (Fenneman, 1931) (fig. 6). The Basin and Range Physiographic Province makes up about 41 percent of the study area, the Middle Rocky Mountains about 58 percent, and the Colorado Plateau less than 1 percent. The Basin and Range Province includes most of the low-altitude area west of the Wasatch Range and is characterized by isolated, subparallel mountain ranges and alluvial valleys. The ranges typically are bounded by highangle block faults with normal faults defining the edges of the range. The alluvial basins are typically composed of Tertiary- and Quaternary-aged sediment eroded from the adjacent mountain ranges. The Middle Rocky Mountains Physiographic Province includes most of the higher altitudes of the Wasatch and the Uinta Mountains and is characterized by Paleozoic and Precambrian rocks with associated intermontane valleys. The intermontane valleys typically consist of Quaternary- and Tertiary-aged sediment eroded from the adjacent mountains. 


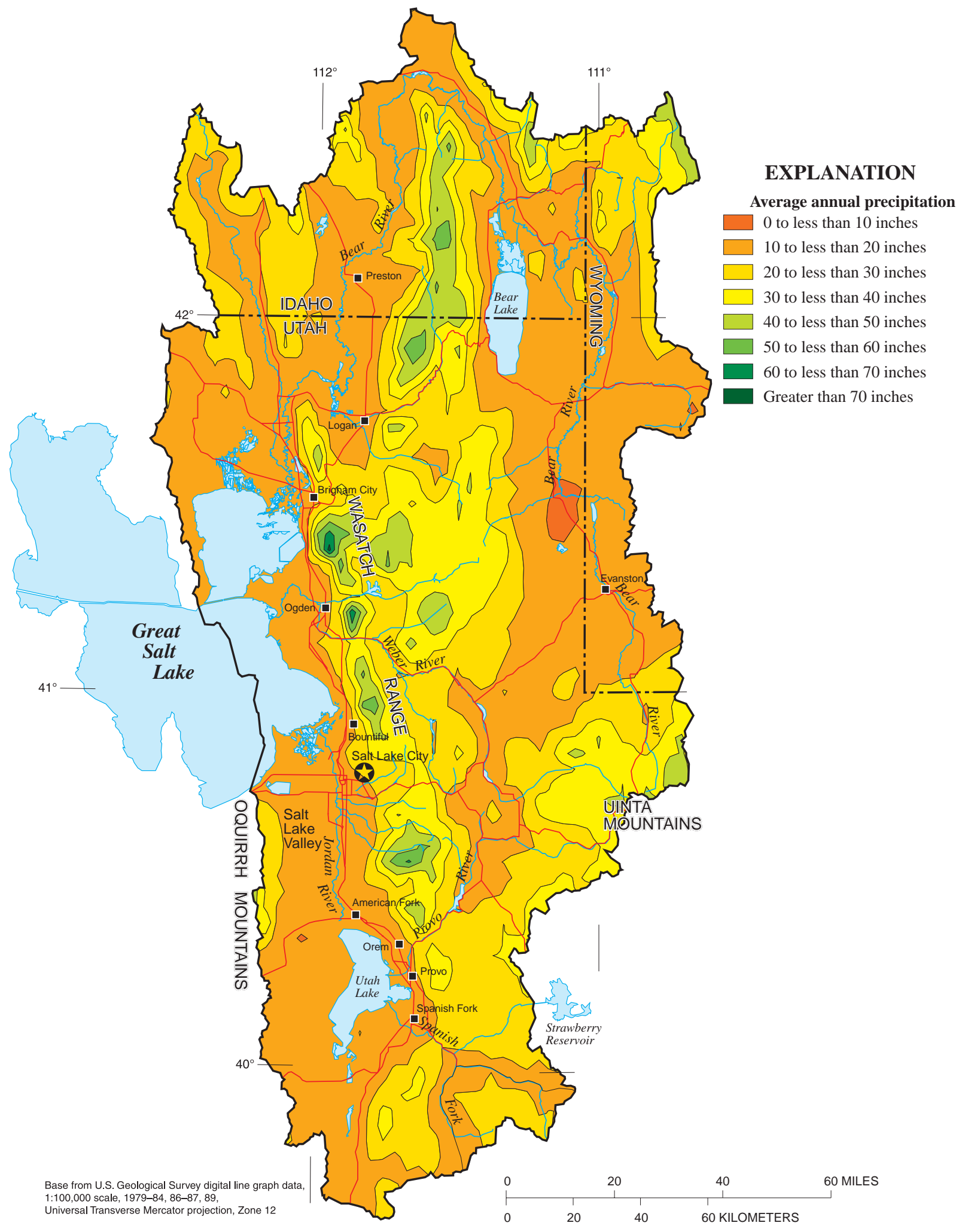

Figure 5. Average annual precipitation of the Great Salt Lake Basins study unit, 1961-90.

Data from U.S. Department of Agriculture, 1998. 


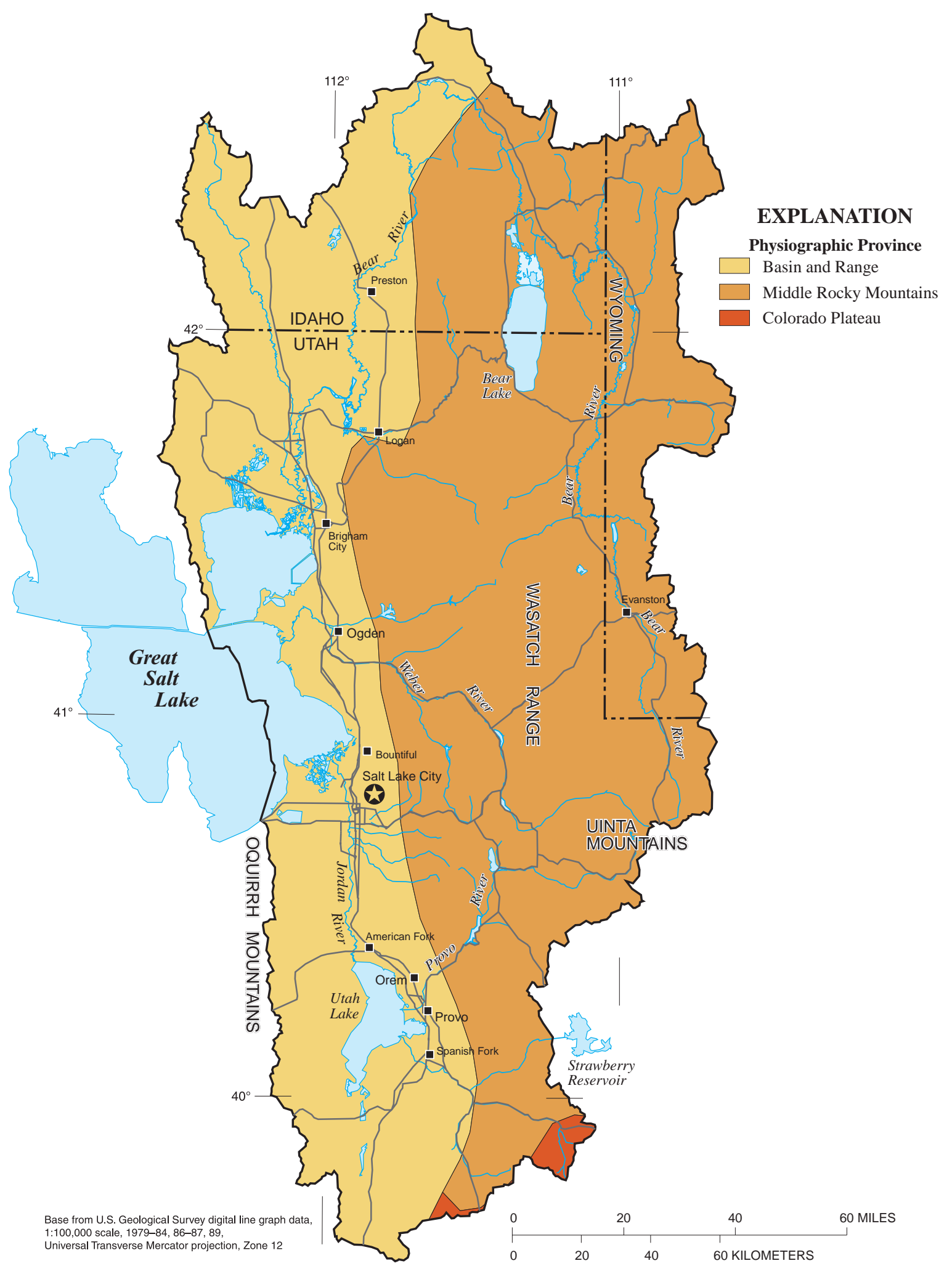

Figure 6. Physiographic provinces of the Great Salt Lake Basins study unit. Data from Fenneman, 1931. 
The north-trending Wasatch Range is approximately the division between the lowlands of the Basin and Range to the west and the mountainous Middle Rocky Mountains area to the east. The Uinta Range is an east-trending range from which the Bear, Weber, and Provo Rivers originate. The alluvial valleys of the Uinta Range are narrow and steep at the higher altitudes and broad and flat as they traverse the lowlands of the Middle Rocky Mountains and Basin and Range Provinces. Streams from these valleys join to form the three major rivers that ultimately discharge to Great Salt Lake.

\section{Geology}

The Bear River, Weber River, and Utah Lake and Jordan River basins have headwaters that originate in Precambrian quartzite in the Uinta Mountains. At the lower altitudes below about 5,200 ft, the rivers and Utah Lake are incised into sediments of recent age. In the intervening area, the geology varies somewhat among the three drainage basins. Rocks ranging in age from Paleozoic to Tertiary underlie and surround unconsolidated basin-fill deposits mostly of Tertiary or Quaternary age. The mountain ranges are composed of rocks of Precambrian and Paleozoic age and the valleys contain Tertiary and Quaternary sediment eroded from the surrounding mountains (fig. 7).

\section{Bear River Basin}

The older rocks of this area are predominantly limestones and dolostones of Paleozoic age (Dover, 1987). The younger rocks, such as breccias, conglomerates, sandstones, and siltstones, are of Tertiary and Quaternary age and are lithified sediments that developed from faulting and folding events, glacial deposits, and deposits of Pleistocene-age Lake Bonneville (about 26,000 to 16,000 years ago) (Arnow, 1984). The soils in the Bear River basin were derived from the bedrock beneath and surrounding the valleys.

\section{Weber River Basin}

The Weber River basin is composed principally of sedimentary deposits (Utah Department of Natural Resources, 1997c) underlain by older Precambrian, Paleozoic, and Mesozoic rocks. The Paleozoic rocks are composed of sedimentary limestone, dolomite sandstone, and shale, with various mixtures of quartzite, and the older Precambrian rocks consist of metamorphic assemblages of gneiss, schist, and quartzite. The Mesozoic rocks are composed principally of sandstone, siltstone, and shale. The sedimentary deposits in the headwater area of the Weber River contain extensive deposits of highly permeable glacial material of Quaternary age and are generally composed of gravel and fine-textured sand, silt, and clay. Most Quaternary sedimentary deposits in this area are highly permeable and may retain large volumes of water during periods of high runoff. Generally, the older Precambrian, Paleozoic, and Mesozoic rocks are the least permeable.

\section{Utah Lake and Jordan River Basins}

The western valleys of the Utah Lake and Jordan River Basins are in the Basin and Range Physiographic Province and are composed of Tertiary- and Quaternary-age sediments. The mountains to the east are part of the Middle Rocky Mountain Physiographic Province and are made up of Paleozoic and Precambrian rocks. The intermontane valleys contain Quaternary-age sediments. A small area of the Utah Lake basin located south of the Uinta Mountains and east of the Wasatch Range is part of the Colorado Plateau Physiographic Province and is composed of rocks of Mesozoic age and younger (fig. 7).

\section{Lake Bonneville}

Lake Bonneville was a large inland sea that covered much of the western half of Utah and the southeastern corner of Idaho during the late Pleistocene epoch (fig. 8). In times of greater humidity and glacial activity, Lake Bonneville covered more than 20,000 $\mathrm{mi}^{2}$ with a water-level altitude about $1,000 \mathrm{ft}$ above the present altitude of Great Salt Lake (4,200 ft) (Hunt and others, 1953). As the lake receded, wave-cut terraces on the lower slopes of the mountains and deposits of sand and gravel on the benches were exposed.

The eastern boundary of the Lake Bonneville shoreline coincides approximately with the boundary between the Basin and Range and the Middle Rocky Mountains Physiographic Provinces (fig. 6) (Fenneman, 1931). The lake had two major stages, the Bonneville and the Provo. The Bonneville stage was the earlier of the two, with an average lake-level altitude of about 5,100 ft. During the most recent ice age (Pleistocene), conditions were generally wetter and cooler. The lake continued to fill to an altitude of 5,250 $\mathrm{ft}$, at which it overflowed into the Snake River Valley 


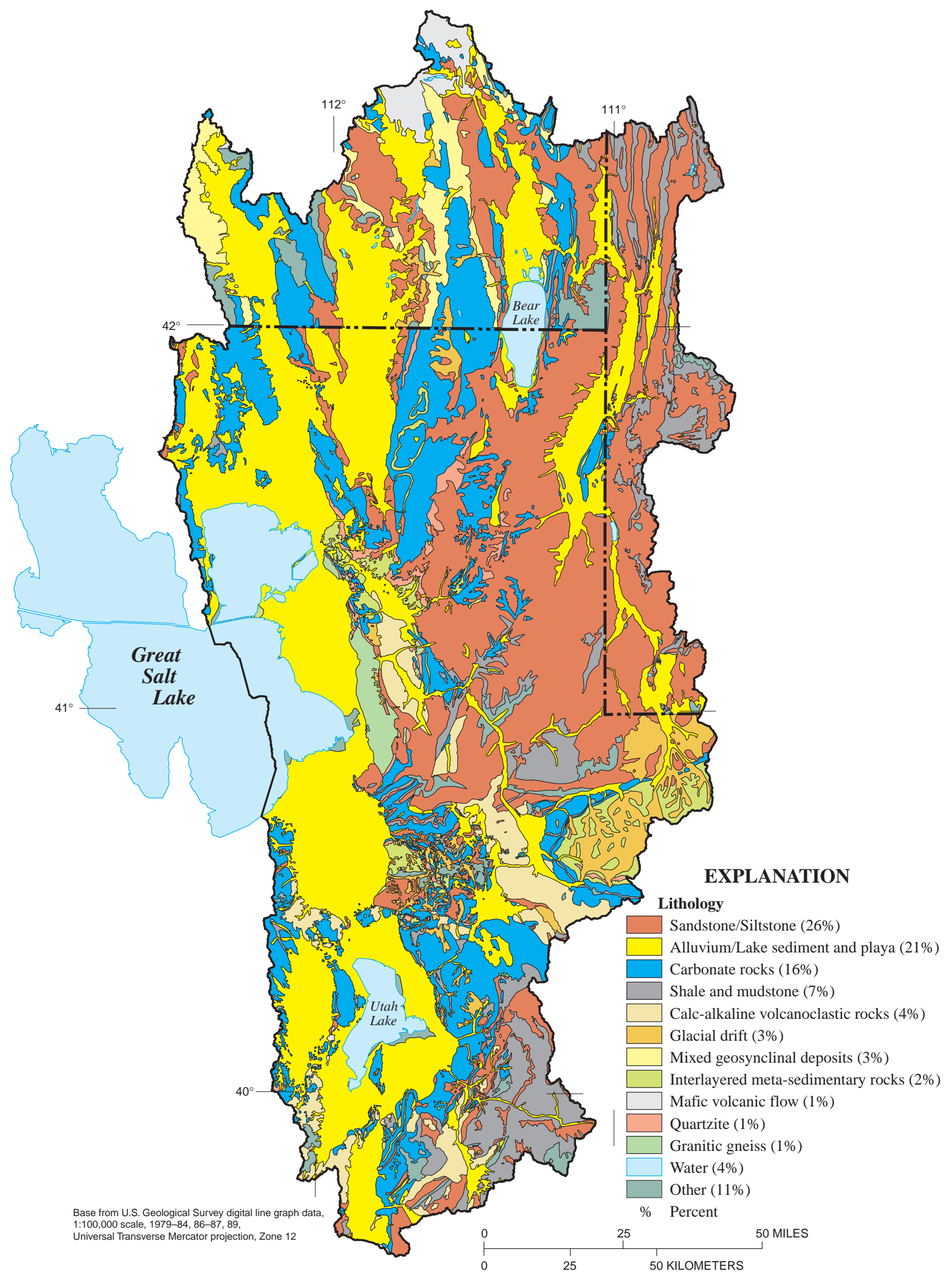

Figure 7. Surficial lithology of the Great Salt Lake Basins study unit.

Data from Johnson and Raines, 1995. 


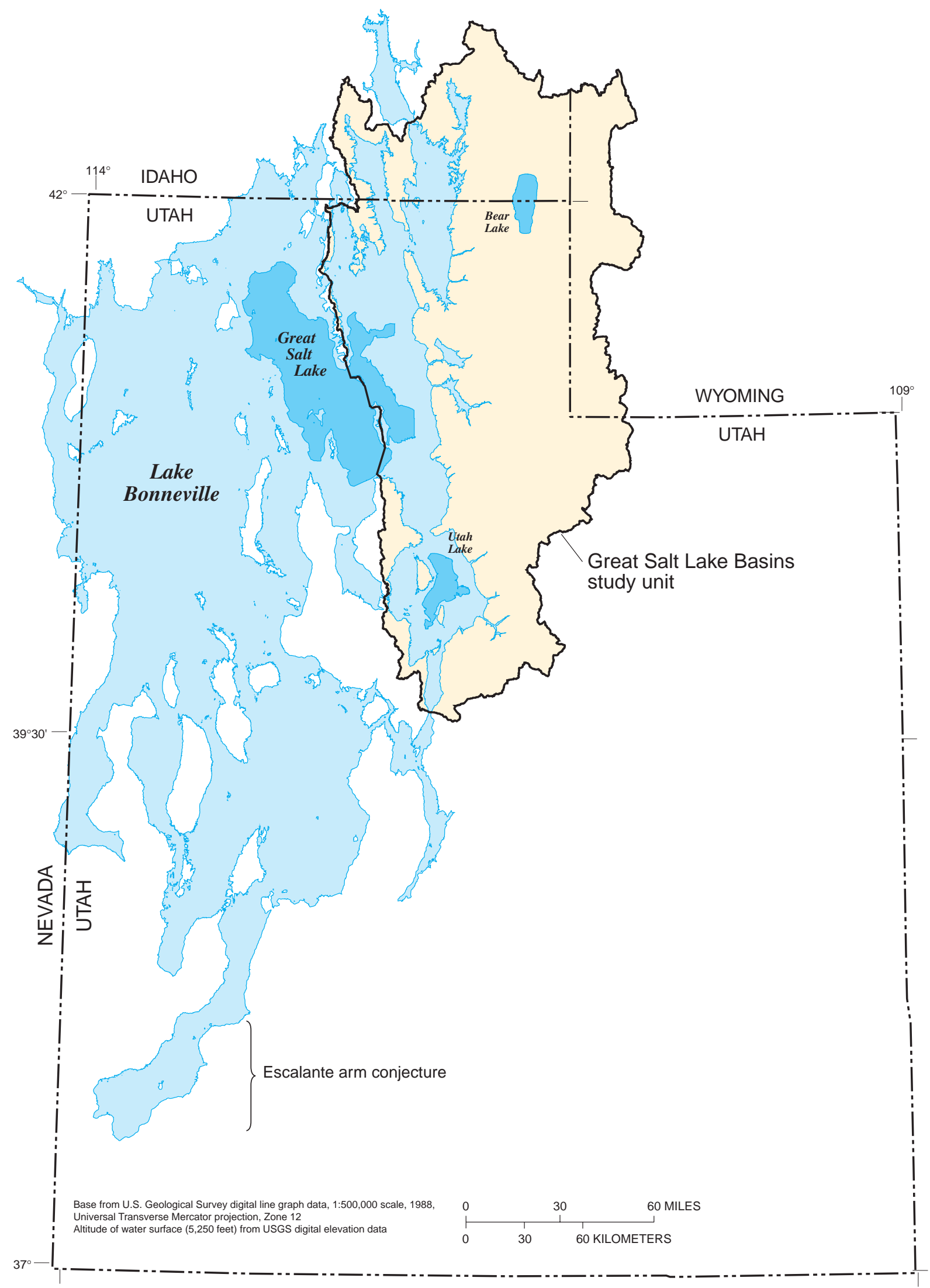

Figure 8. Approximate extent of Pleistocene-age Lake Bonneville, Utah, Idaho, and Nevada. 
by way of Red Rock Pass (Gilbert, 1890). The lake level declined rapidly (about $350 \mathrm{ft}$ ) to the level of the Provo stage about 14,500 years ago.

The decline of Lake Bonneville to the Provo stage permitted rivers and streams to erode deep channels into the unconsolidated sediments of the earlier terraces and bench deposits, and to redeposit that sediment as broad low fans farther out into the valleys. Deltas of interfingering deposits of clay, silt, and sand cap the outer edges of the lake shoreline and are deeply incised by stream channels. The unconsolidated sediments are easily eroded and are susceptible to landslides, especially when saturated. Although erosion and the subsequent sediment loading of the streams are part of a natural process, land-use activities such as land development for domestic and commercial buildings, overgrazing by livestock, and channel modification for irrigation have accelerated the erosion process.

\section{Soils}

Soil associations vary widely throughout the GRSL study unit and include poorly drained, nearly level, loamy soils on low-lake terraces (ChipmanMcBeth association) to moderately steep and steep soils that have a very cobbly sandy clay loam, gravelly clay, and cobbly silty clay loam subsoil in the high mountains (Lucky Star-Cluff-Bickmore association) (U.S. Department of Agriculture, 1972 and 1974, respectively). In general, the soils of the valleys in the higher altitudes of the three major drainage basins are developed from alluvial sediments on flood plains, alluvial fans, and footslope areas at the base of the mountains. The soils are generally well drained (fig. 9) and contain more than 70 percent sand and silt (U.S. Department of Agriculture, 1994). Quartzites and sandstones are the predominant parent material for the alluvium found in the upper valleys. Located so close to the source of parent materials, the valley fill in the upper valleys consists mainly of coarse sands and gravels. Where soils exist at the higher altitudes, they generally consist of medium- to fine-textured loams and overlie coarser-grained sand and gravel. Below an altitude of about 5,600 ft, valley soils have developed from sediments deposited in ancient Lake Bonneville. Much of the soil along the edges of the valleys is medium to coarse textured. The lake terraces and finer materials, widely distributed on the broader interior floor of the valleys, were deposited during postBonneville times and form the basis for soil associations at the lower altitudes.

In general, arable lands of the basin have good water transmission properties and adequate moistureholding capacity, which, with other favorable physical and chemical properties, make them well suited for irrigated agriculture. Many of the soils in the upper valleys have a high to very high susceptibility to erosion, and many of the rivers in these areas reflect this condition through high concentrations of suspended sediment. Saline conditions near Great Salt Lake limit much of the area around the lake to nonagricultural use.

\section{Vegetation}

Mountainous areas in the GRSL study unit are characterized by forests and alpine vegetation. The species range from an Engleman spruce/subalpine fir zone interspersed with alpine meadows at the highest altitudes, through a zone of douglas fir and aspen to scrub oak and mountain mahogany at the lower altitudes. The valleys are characterized by grasslandtype vegetation, often dominated by sagebrush. The higher-altitude grasslands also contain graminids such as wheatgrass, and lower-altitude grasslands support saltbrush and greasewood.

Great Salt Lake is bordered on the east and south by numerous freshwater and saltwater marshes. These marshes lie along the central flyway for migratory birds and are extremely important to migrating waterfowl. An estimated 268 species of birds regularly visit the marshes at Bear River Migratory Bird Refuge (Vickie Roy, U.S. Fish and Wildlife Service - Bear River Migratory Bird Refuge, oral comm., 2001). The Jordan River was once bordered by extensive acres of freshwater wetlands from Utah Lake through the valley to Great Salt Lake (Halpin, 1987). Many of these have been reduced in size or eliminated by encroaching urban development, but restoration of this corridor is ongoing. 


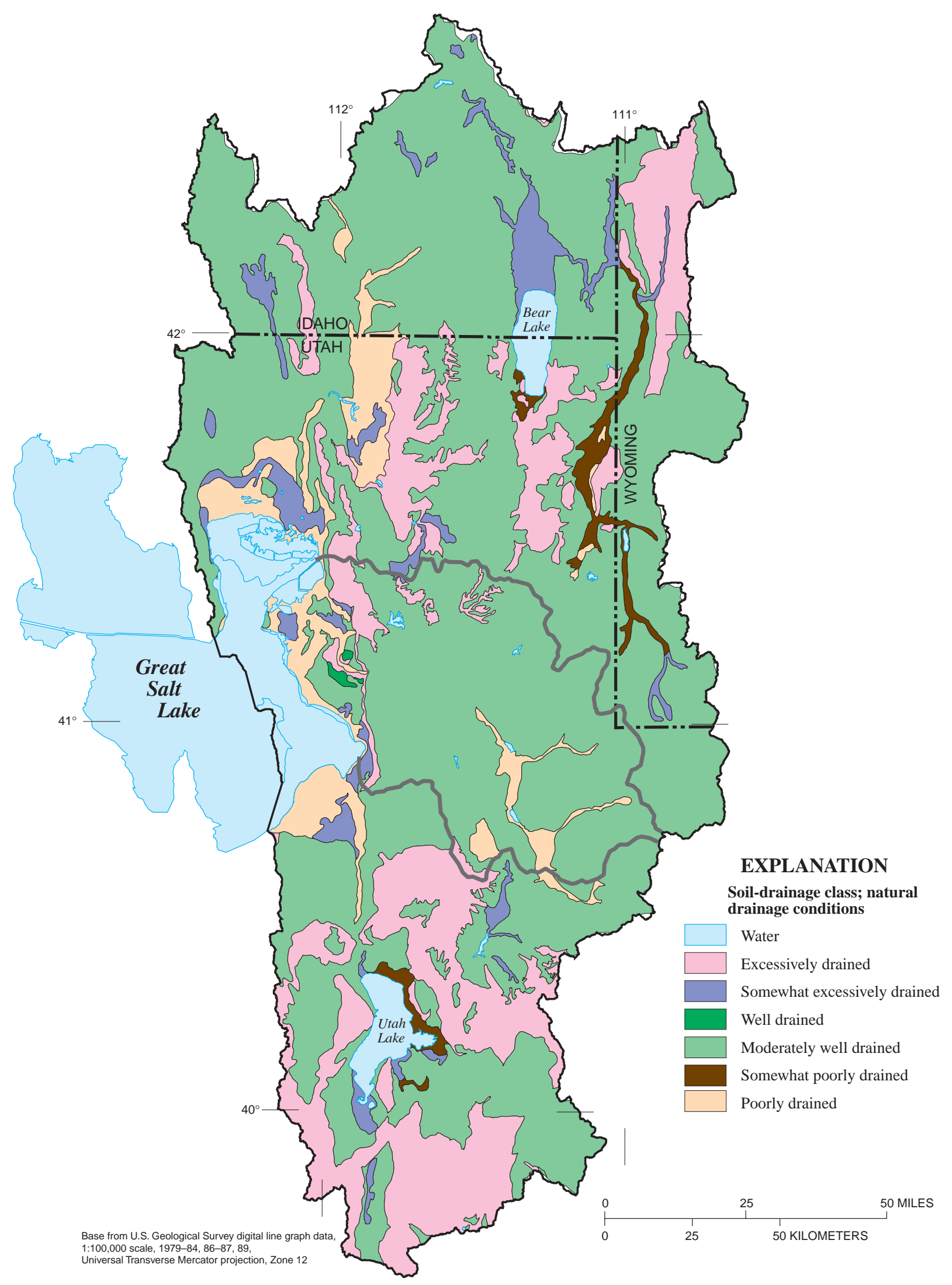

Figure 9. Generalized soil-drainage characteristics of the Great Salt Lake Basins study unit. Data from U.S. Department of Agriculture, 1994. 


\section{Surface Water}

Total average annual surface-water discharge from the three river systems in the GRSL study unit during 1931-76 was 2.98 million acre-ft/yr (Waddell and Barton, 1980). Of this total, about 62 percent is discharged by the Bear River basin, 23 percent by the Weber River basin, and 15 percent by the Utah Lake/Jordan River basins.

Schematic discharge diagrams for the Bear, Weber, Provo, and Jordan River basins (Utah Department of Natural Resources, 1992, 1997a, 1997b, 1997c) were rescaled and joined to create a single scale-consistent schematic for the entire GRSL NAWQA study unit (fig. 10). The schematic diagrams are based on existing long-term records for streamflowgaging stations. The gaging stations were operated for varying periods and no attempt was made to estimate the discharge records for a common time period. Consequently, only an estimated annual discharge is shown in figure 10.

\section{Streamflow and Storage}

Streamflow in the GRSL study unit changes in response to seasonal variations of precipitation, temperature, and evapotranspiration, and humaninduced hydrologic modifications resulting from dams and diversions. Most of the major unregulated streams and tributaries naturally peak during May to June with the discharge peak in lower-altitude drainages occurring earlier. At some sites, streamflow is controlled by dams that create major lakes or reservoirs and the peak runoff period is altered. Seasonal variations of streamflow at selected gaging stations in the GRSL study unit are shown in figure 11. Reservoirs on the Bear, Weber, Provo, and Jordan Rivers, and their tributaries, modify the natural hydrologic variability of the streams and affect the physical, chemical, and biological conditions of the streams and adjacent areas.

Bear Lake, with a usable storage capacity of $1,421,000$ acre- $\mathrm{ft}$, is the largest reservoir in the Bear River basin and regulates the streamflow of the Bear River below its outlet. A comparison between the Bear River near Cokeville, Wyoming (above Bear Lake), and the Bear River at Pescadero, Idaho (just downstream from Bear Lake), shows that peak streamflow above the lake is in June, and just below the lake at the Pescadero site, peak streamflow occurs in July. The different peak streamflow pattern at the Pescadero site compared to the Cokeville site is the result of storage and release patterns from Bear Lake for irrigation downstream.

\section{Aquatic Habitat and Biota}

Streams in the GRSL study unit include a variety of habitats. Much of the study unit is mountainous and mountain streams are characterized by rapid and abrupt changes in habitat, from cascades and fast rapids to calm, deep pools. Similar habitat types are often isolated from one another by areas of swift current and thus can form "islands" for the organisms in the river (Gaufin, 1959). Headwater streams and small creeks and tributaries begin mostly in the high mountain ranges in the central and eastern part of the study unit. These streams have steep gradients, cold water, and often have rocky or boulder substrates. As the streams lose altitude and become larger, they flow through alternating stretches of steep-walled canyons and open meadows. The canyons are characterized by moderate to high gradients, narrow walls, and low sinuosity. The meadow areas have low gradients, higher sinuosities, and often have wetlands and oxbow cutoffs along the riparian corridor.

The Bear, Weber, and Jordan Rivers all form deltas at the terminus of their courses, where they enter bay areas of Great Salt Lake. Depending on the level of the lake, these deltas form wetland complexes that grade from freshwater to brackish and salt water. The Bear, Weber, and Jordan Rivers are meandering upstream from the bay areas and prior to human development were characterized by extensive wetland areas.

Humans have altered the natural form of many of these rivers. In headwater areas, logging, mining, and more recently, recreation and residential construction, have increased erosion and degraded water quality. In the valley areas, agriculture, grazing and urbanization have removed many of the natural wetlands and riparian vegetation, channelized reaches in some areas, and contributed nutrients and sediments to the streams. Hydrologic modifications in the canyon areas include channelization for road construction and construction of reservoirs for drinking water, agricultural supplies, or hydroelectric power. More than 25 reservoirs with more than 5,000 acre-ft of capacity exist in the GRSL study unit and alter the daily, seasonal, and annual flow regimes of the rivers. 


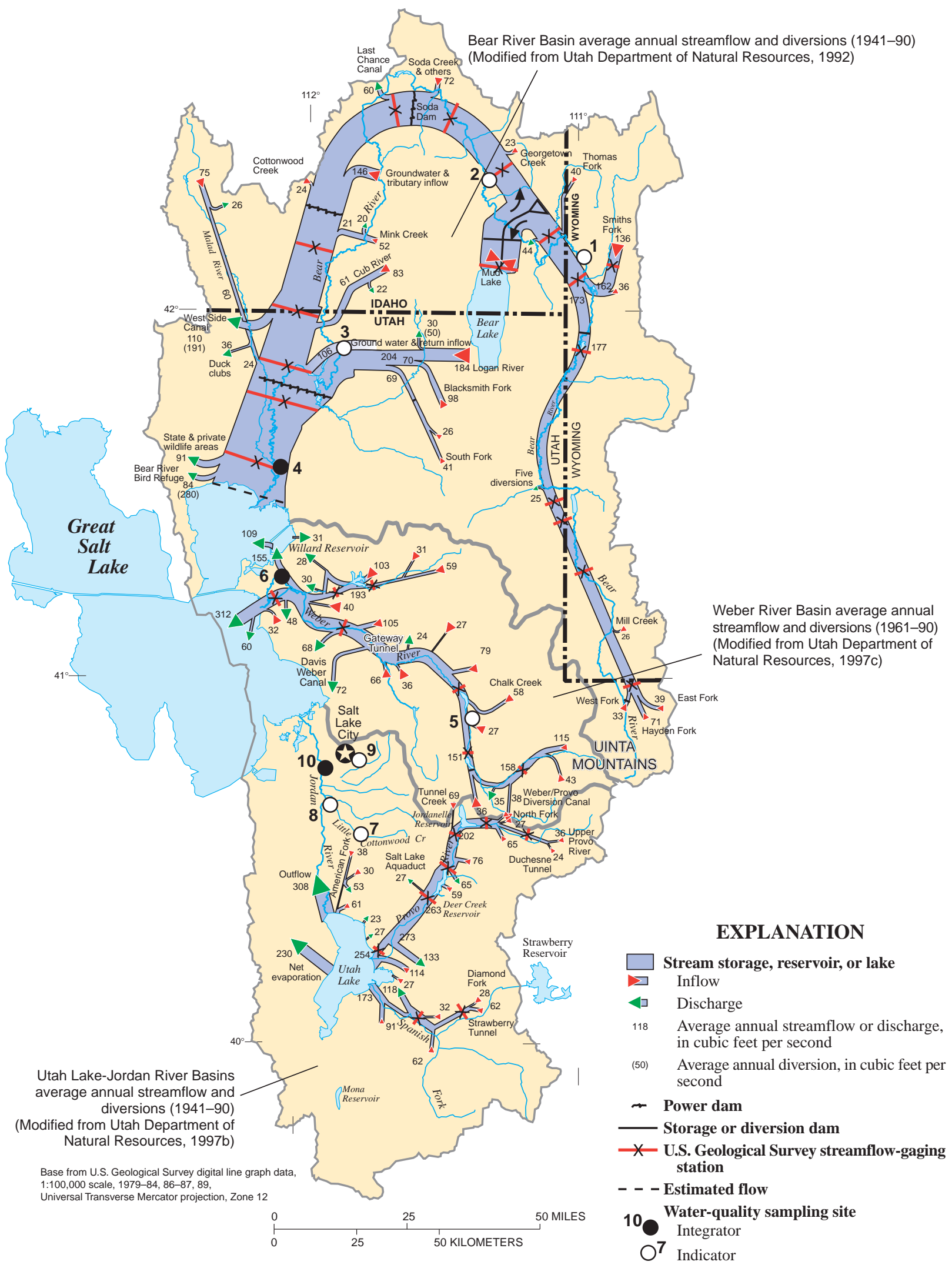

Figure 10. Estimated annual discharge for streams in the Great Salt Lake Basins study unit. 

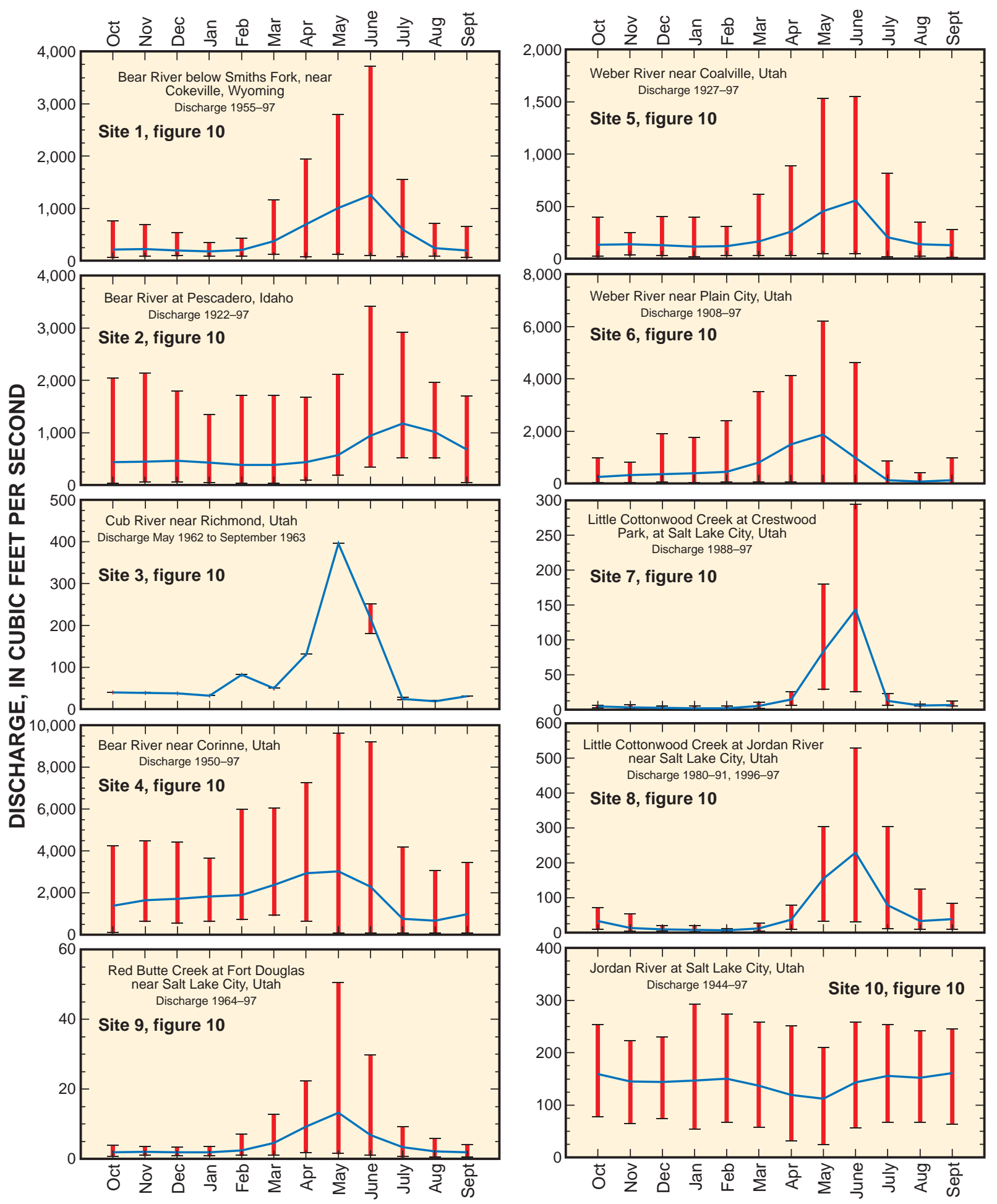

EXPLANATION

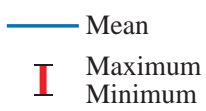

Figure 11. Seasonal variations in streamflow at selected sites in the Great Salt Lake Basins study unit. Data for site 3 from U.S. Geological Survey,1970; data for all other sites from Herbert and others, 1998. 
These alterations have substantial effects on the habitat and therefore on the biota of the rivers.

Urbanization in Salt Lake Valley has caused channelization, dewatering, and contamination in the Jordan River and its tributaries (U.S. Environmental Protection Agency, 1973; Environmental Dynamics, 1975). Attempts to channelize and control the Jordan River have resulted in channel instability, and recent studies have recommended allowing development of a meander corridor closed to development $(\mathrm{CH} 2 \mathrm{M}$ Hill, 1992). The presence of many hazardous waste and contamination point sources have affected the biota and water quality of the Jordan River (Environmental Dynamics, 1975). During the 1960s only the most tolerant organisms could survive in the river (Hinshaw, 1967; Way, 1980). More recently, the Jordan River has been the focus of water-quality clean-up efforts and several species of warm water game fish are again supported in some reaches of the river (Crist and Holden, 1991).

Little Cottonwood Creek is typical of streams along the urban Wasatch Front. This stream drains a steep canyon and then flows across Salt Lake Valley before entering the Jordan River. In the upper reaches, waste products from mining activities have affected the water quality and biota (Jensen, 1991). After Little Cottonwood Creek enters Salt Lake Valley, it flows through a complicated set of diversions and return flows of water. Some reaches of the stream are completely dewatered during parts of the year. In reaches with sufficient flow, a limited fishery has been supported (EDAW Inc., 1979). Other Wasatch Front streams experience similar hydrologic modifications and habitat degradation.

The composition of aquatic communities depends on stream environment. The distribution of aquatic invertebrates and algae is determined by local habitat characteristics such as substrate size and type, stream velocity, availability of food sources, and water temperature (Stevenson and others, 1996). These factors are controlled to some extent by geologic and hydrologic characteristics of the watershed. For example, the geologic character of the watershed influences the stream $\mathrm{pH}$ and alkalinity, which affect invertebrate populations in the study unit (Anderson, 1963; Osborn, 1981). The topographic character of the watershed influences slope, which in turn affects substrate size (Leopold and others, 1964).
The native fishery of the basin is limited in diversity and has been affected by non-native introductions of fish (Holden and others, 1996) (table 1). The native fishery consisted of about 14 species including cutthroat trout, mountain whitefish, a few sucker species, Utah chub, and several minnow species. Utah Lake was especially noted in early accounts for large populations of trout, whitefish, and suckers that were plentiful and easy to catch in the spring. Because fishing was more difficult in the summer, exotic species were introduced, originally as a protein supplement to the diet (Sigler and Miller, 1963). Over the years, stocking of exotic game fish for angling, along with accidental introductions, have led to a significant change in the fishery, especially in the warm waters of the basin. Today, at least 20 exotic species are common, with trout such as rainbow and brown dominating in cold waters at higher altitudes and introduced warm-water fishes such as carp, bass, walleye, sunfish, and catfish dominating in warmer waters at lower altitudes (table 1).

The number of native fish species has declined. One native fish species, the June sucker, is listed as endangered (U.S. Fish and Wildlife Service, 1995) and two native fish species, the Bonneville cutthroat trout and the least chub, are listed as sensitive and have been considered for Federal listing. Both species are now covered by conservation plans to help aid their recovery (Perkins and others, 1997; Utah Division of Wildlife Resources, 1996). One native fishery that has remained intact is Bear Lake, which supports Lacustrian cutthroat trout, as well as four species of fish that occur nowhere else: Bonneville cisco, Bear Lake sculpin, Bonneville whitefish, and Bear Lake whitefish. Unique water chemistry has favored these native species over introduced sport fish. A lake trout population is maintained in Bear Lake through stocking.

The Bonneville cutthroat trout, once believed to be extinct, has been the focus of many studies and surveys. Populations of this subspecies (considered 95 percent or more pure) once occupied virtually every suitable habitat in the basin but are now limited to small headwater streams, mostly on national forest lands (Duff, 1996). Major detriments to this species are interbreeding with introduced rainbow and Yellowstone cutthroat trout, habitat alterations that reduce migration and isolate populations, and removal 
Table 1. Fish species in the Great Salt Lake Basins study unit

[Scientific name as reported by American Fisheries Society, 1991: SS, Sigler and Sigler, 1996; CH, Crist and Holden, 1991]

\begin{tabular}{|c|c|c|}
\hline Common name & Scientific name & Reference \\
\hline \multicolumn{3}{|c|}{ Native fish } \\
\hline Bonneville cutthroat trout $^{1}$ & Oncorhynchus clarki utah (Suckley) & SS \\
\hline Mountain whitefish & Prosopium williamsoni (Girard) & SS \\
\hline Bonneville whitefish & Prosopium spilonotus (Snyder) & SS \\
\hline Bear Lake whitefish & Prosopium abyssicols (Snyder) & SS \\
\hline Bonneville cisco & Prosopium gemmifer (Snyder) & SS \\
\hline Utah sucker & Catostomus ardens (Jordan and Gilbert) & SS \\
\hline June sucker ${ }^{1}$ & Chasmistes liorus Mictus (Miller and Smith) & SS \\
\hline Mountain sucker & Catostomus platyrhynchus (Cope) & SS \\
\hline Bluehead sucker & Catostomus discobolus (Cope) & SS \\
\hline Utah chub & Gila atraria (Giard) & SS \\
\hline Least chub ${ }^{1}$ & Iotichthys phlegethontis (Cope) & SS \\
\hline Leatherside chub & Gila copei (Jordan and Gilbert) & SS \\
\hline Redside shiner & Richardsonius balteatus (Richardson) & SS \\
\hline Speckled dace & Rhinichthys osculus (Girard) & SS \\
\hline Longnose dace & Rhinichthys cataractae (Valenciennes) & SS \\
\hline Mottled sculpin & Cottus bairdi (Girard) & SS \\
\hline Paiute sculpin & Cottus beldingi (Eigenmann and Eigenmann) & SS \\
\hline Bear Lake sculpin & Cottus extensus (Snyder) & SS \\
\hline Utah Lake sculpin (extinct) & Cottus echinatus (Bailey and Bond) & SS \\
\hline \multicolumn{3}{|c|}{ Introduced Fish } \\
\hline Kokanee & Oncorhynchus nerka (Walbaum) & SS \\
\hline Yellowstone cutthroat trout & Oncorhynchus clarki lewisi (Girard) & SS \\
\hline Cutthroat trout hybrids & Oncorhynchus clarki & SS \\
\hline Rainbow trout & Oncorhynchus mykiss (Walbaum) & SS \\
\hline Brown trout & Salmo trutta (Linnaeus) & SS \\
\hline Brook trout & Salvelinus fontinalis (Mitchill) & SS \\
\hline Golden trout & Oncorhynchus aguabonita (Jordan) & SS \\
\hline Lake trout & Salvelinus namaycush (Walbaum) & SS \\
\hline Arctic grayling & Thymallus arcticus (Pallas) & SS \\
\hline Gizzard shad & Dorosoma cepedianum (LeSueur) & SS \\
\hline Common carp & Cyprinus carpio (Linnaeus) & SS \\
\hline Golden shiner & Notemigonus crysoleucas (Mitchill) & $\mathrm{CH}$ \\
\hline Emerald shiner & Notropis atherinoides (Rafinesque) & SS \\
\hline Spottail shiner & Notropis hudsonius (Clinton) & SS \\
\hline Fathead minnow & Pimephales promelas (Rafinesque) & $\mathrm{CH}$ \\
\hline Goldfish & Carassius auratus (Linnaeus) & $\mathrm{CH}$ \\
\hline Channel catfish & Ictalurus punctatus (Rafinesque) & SS \\
\hline Black bullhead & Ameiurus melas (Rafinesque) & SS \\
\hline Rainwater killifish & Lucania parva (Baird and Girard) & SS \\
\hline Western mosquitofish & Gambusia affinis (Baird and Girard) & SS \\
\hline White bass & Morone chrysops (Rafinesque) & SS \\
\hline Largemouth bass & Micropterus salmoides (Lacepede) & SS \\
\hline Smallmouth bass & Micropterus dolomieui (Lacapede) & $\mathrm{CH}$ \\
\hline Green sunfish & Lepomis cyanellus (Rafinesque) & SS \\
\hline Bluegill & Lepomis macrochirus (Rafinesque) & SS \\
\hline Sacramento perch & Archoplites interruptus (Girard) & SS \\
\hline Black crappie & Pomoxis nigromaculatus (LeSueur) & SS \\
\hline Yellow perch & Perca flavescens (Mitchill) & SS \\
\hline Logperch & Percina captrodes (Ratinesque) & SS \\
\hline Walleye & Stizostedion vitreum (Mitchill) & SS \\
\hline
\end{tabular}

${ }^{1}$ Threatened or endangered. 
of viable habitat. Once extremely abundant in Utah Lake, the species has been eradicated from this lacustrine environment (Duff, 1996).

\section{Ground Water}

Ground water in the GRSL study unit is contained within unconsolidated basin-fill deposits in the valleys and basins and consolidated rocks in the mountains (fig. 12). The basin-fill deposits are the principal source of ground water for domestic and municipal supply and for irrigated agriculture in the study area. The deepest and oldest parts of the basinfill deposits are composed of sediments that were eroded from adjacent mountain ranges and have subsequently become semiconsolidated to consolidated by compaction and cementation. The shallower, younger basin-fill deposits consist of interbedded lacustrine and alluvial sediments that are less compacted and cemented and generally are more permeable than the underlying, older deposits. The most permeable sediments are remnants of large preLake Bonneville alluvial fans and Lake Bonneville deltas and are composed mainly of gravel and sand deposited near the mountain fronts. These coarser materials form the principal basin-fill aquifers in Cache Valley, the lower Bear River area, the East Shore area of Great Salt Lake, Salt Lake Valley, and Utah and Goshen Valley and provide ground water for multiple uses to 84 percent of the population of Utah (Anderson and others, 1994).

The basin-fill aquifers in the study unit are classified into two types: shallow aquifers and principal aquifers. The shallow, generally unconfined aquifers consist primarily of coarse-grained basin-fill deposits that are separated from the confined part of the principal aquifers by fine-grained sediments which form discontinuous confining layers. The shallow aquifers contain the water table or the first saturated zone in the subsurface and generally occur in the secondary recharge areas and discharge areas (fig. 12). The land overlying the shallow ground water has been developed mainly for agricultural, commercial, industrial, and residential purposes. The shallow aquifers are typically present within the upper $50 \mathrm{ft}$ of basin-fill deposits and therefore are vulnerable to contamination because of their proximity to human activities at land surface. Low yields and poorer quality limit the use of water from the shallow aquifers.
The principal aquifer in each basin or valley includes a deeper unconfined aquifer along the mountain front that becomes confined where overlain by confining layers (fig. 12). Layers of clay, silt, sandy clay, or silt and clay more than $20 \mathrm{ft}$ thick are classified by Anderson and others (1994) as confining layers. The occurrence of the deeper unconfined part of the principal aquifer in a basin corresponds with that of primary recharge area and a lack of substantial confining layers (fig. 12). It may occupy a relatively narrow area if the confining layers are close to the mountain front. The depth to the water table is typically from 150 to $500 \mathrm{ft}$ below land surface. The land above the deeper unconfined aquifers in the study unit has generally been undeveloped or is used for residential and commercial purposes, but as population increases, more land is being developed for residential and commercial use. These aquifers are vulnerable to contamination and are a major source of drinking water within the study unit.

The deeper confined part of the principal aquifer in each subarea is recharged by the adjacent deeper unconfined aquifer and by the overlying shallow aquifer where a downward hydraulic gradient exists and the confining layers are discontinuous. It is susceptible to contamination by flow reversals caused by large amounts of ground-water withdrawals and is also a major source of drinking water within the study unit.

Perched aquifers generally occur above localized lenses of finer-grained deposits overlying the deeper unconfined aquifers. They can be the source of water to springs used for agricultural and stock purposes.

Perched aquifers are not areally extensive and, therefore, are less likely to receive contamination from land surface.

Bedrock aquifers occur primarily in the mountainous areas of the study unit and supply water to mountain springs that are used for drinking water in some areas of the study unit. Very little ground water is withdrawn from consolidated rocks where thick basinfill deposits are present. Consolidated-rock formations in the study area are considered part of the principal aquifer when they are in direct contact with and have hydraulic connection with basin-fill deposits. 


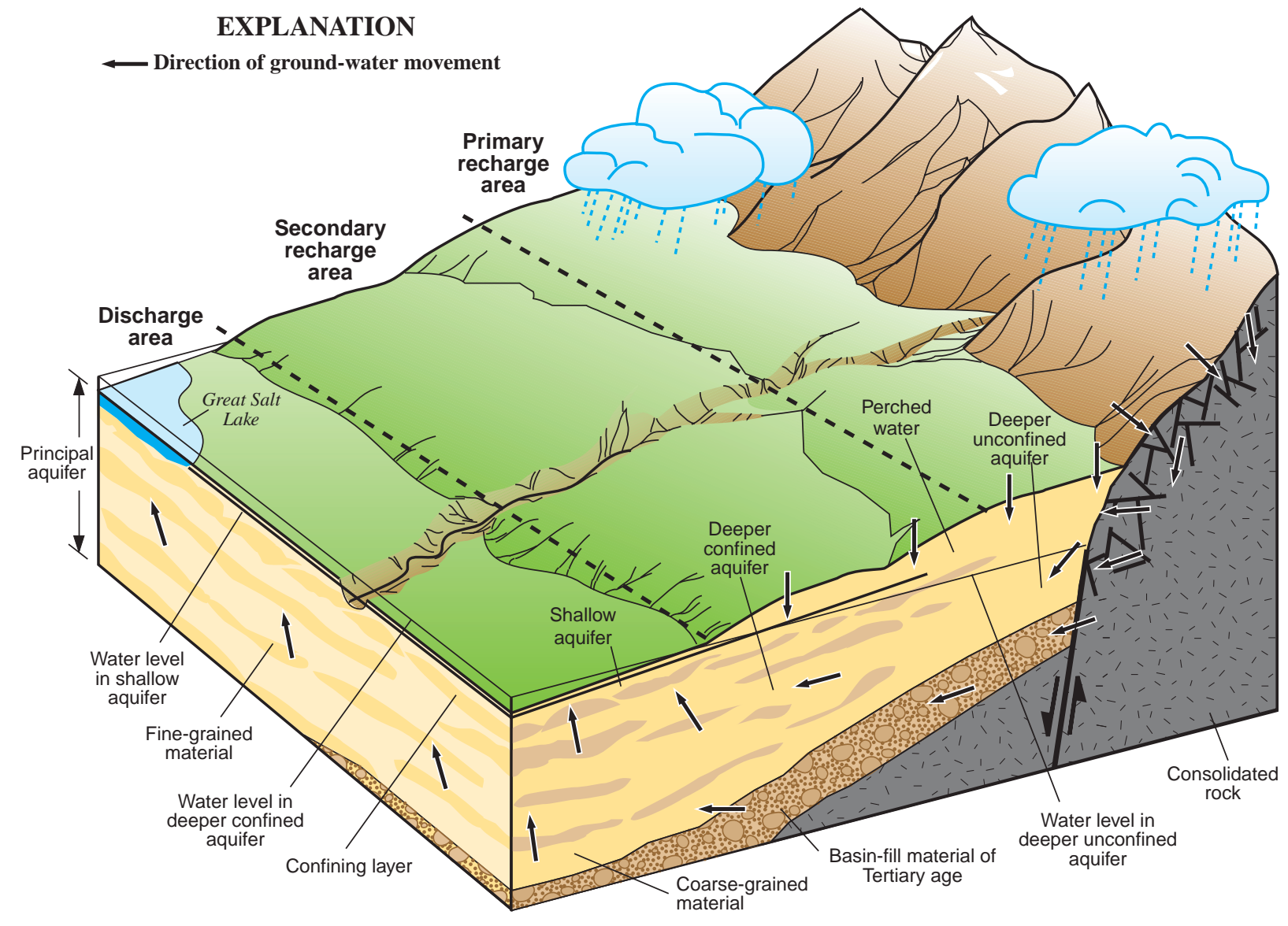

Figure 12. Generalized block diagram showing the basin-fill deposits and ground-water flow system in Salt Lake Valley, Utah. Modified from Hely, Mower, and Harr, 1971. 
Ground water in the study unit generally comes from precipitation on the mountains or on valley benches where it infiltrates into the soil and downward through the basin-fill deposits to the principal aquifers. Ground water in the principal aquifer in each subarea flows toward the center of the valley and discharges to springs, streams, lakes, and upward to the shallow aquifer. The coarse-grained deposits along the mountain fronts are important recharge areas. The identification of recharge areas is necessary for the protection of ground-water quality because recharge areas generally have higher hydraulic-conductivity values, and ground water typically moves rapidly from the land surface into the unconfined part of the principal aquifers. Recharge and discharge areas were mapped by Anderson and others (1994) (fig. 13) on the basis of hydrologic information, water-level data, and drillers' lithologic logs for 2,828 wells, and geophysical logs from wells. Classifications of recharge and discharge areas were qualitative, and no estimates of recharge or discharge were made. Areas are classified as primary recharge areas, secondary recharge areas, or discharge areas on the basis of the following definitions (Anderson and others, 1994, p. 6).

Primary Recharge Area-where fine-grained basin-fill deposits that form confining layers between the land surface and the water table are not thicker than about $20 \mathrm{ft}$. The occurrence of the deeper unconfined aquifer corresponds with that of primary recharge area.

Secondary Recharge Area-where a confining layer is present between the land surface and the principal aquifer. Where a shallow aquifer is present above the first confining layer, the direction of groundwater movement between the shallow aquifer and the confined part of the principal aquifer generally is downward.

Discharge Area-where the direction of ground-water movement is upward from the confined part of the principal aquifer to the shallow unconfined aquifer. Discharge areas generally occur in the topographically lowest parts of the valleys.

Ground-water-quality data have been collected from the different aquifers in the study unit by several entities. The USGS has analyzed water samples from the aquifers generally for major ions and nitrate concentrations and the results are stored in its National Water Information System (NWIS) database. The Utah Department of Environmental Quality, Division of Drinking Water (DEQ) database contains ground-water data for public-supply wells in the study unit. This database includes concentration values or detection information for major ions, nutrients, pesticides, volatile organic compounds (VOCs), and radionuclides.

The chemical composition of water from the principal basin-fill aquifers in Cache Valley, the lower Bear River area, the East Shore area of Great Salt Lake, Salt Lake Valley, and Utah and Goshen Valley varies from a calcium bicarbonate type to a sodium chloride type depending on the type of rocks and associated minerals that the water has been in contact with. Chemical composition diagrams for ground water sampled from wells completed in the principal aquifers by Anderson and others (1994) are shown in figure 14. The dissolved-solids concentration of deeper ground water in the recharge areas is generally less than 500 milligrams per liter in the study unit (Anderson and others, 1994, pl. 1-5).

\section{Ecoregions}

Ecoregions are relatively homogeneous subdivisions of the natural landscape originally designed for use in water-quality interpretation (Omernik, 1987). The boundaries of the regions are drawn from potential natural vegetation, land-surface form, soils, and land use.

Four ecoregions are present in the GRSL study unit (fig. 15). The largest of these is the Wasatch and Uinta Mountains ecoregion which covers 39 percent of the study area. This region is characterized by the high mountains of the Wasatch and Uinta Ranges, coniferous forest vegetation, dark-colored soils of subhumid regions and forests, and grazed woodland land uses. The Northern Basin and Range ecosystem covers the western part of the study unit (38 percent) and includes the Lake Bonneville basin. This region is characterized by lowland plains separated by northsouth mountain ranges. Within the GRSL study unit, however, only the lowland plains section of this region is represented. Vegetation consists of sagebrush, saltbrush, and greasewood on dry or alkali soils. The major land uses in the Northern Basin and Range ecosystem portion of the GRSL study unit are irrigated agriculture and urban. The Wyoming Basin ecoregion covers 20 percent of the study area. This ecoregion is an area of high plains with relatively low mountains or hills dominated by sagebrush steppe vegetation 


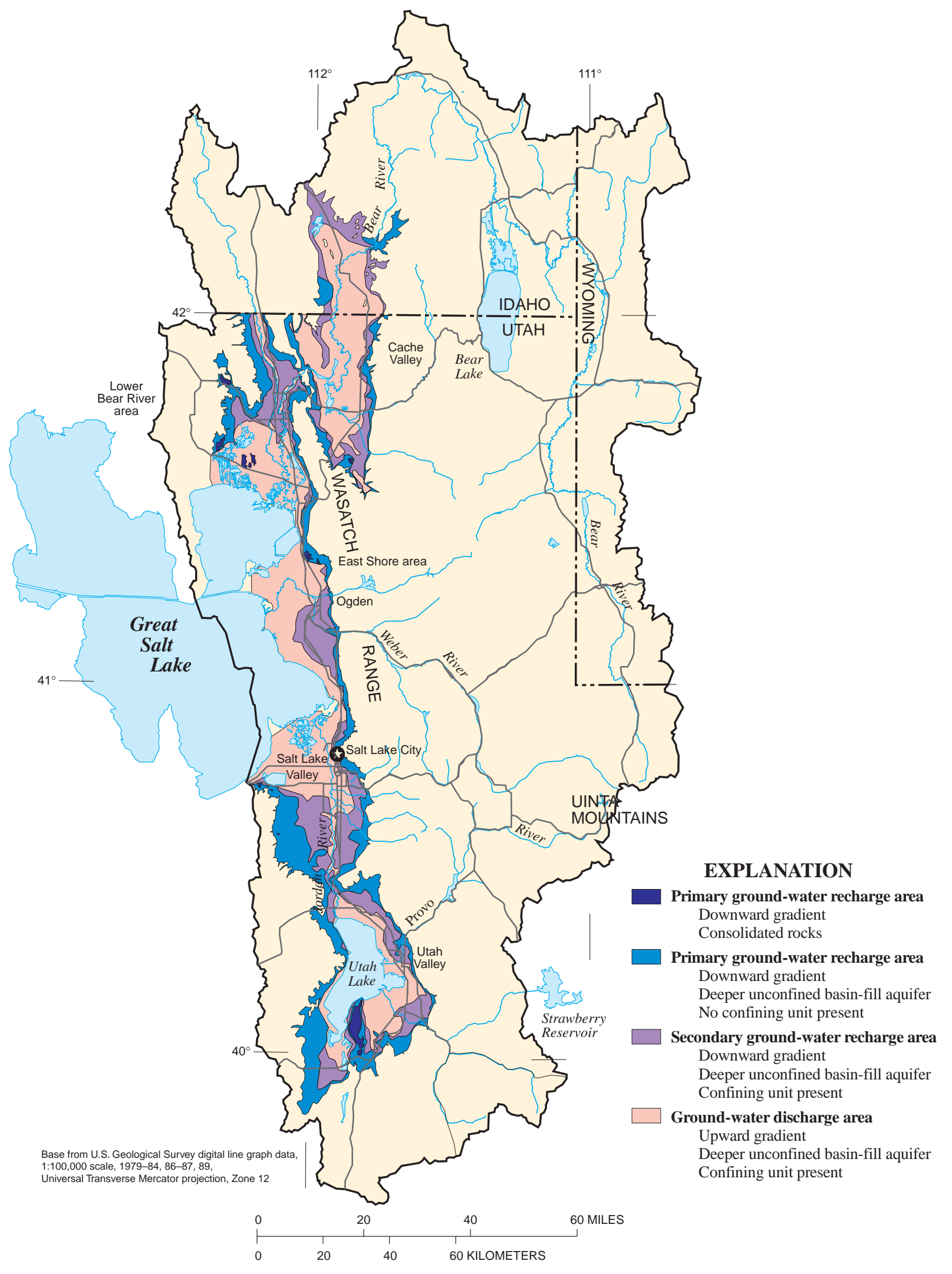

Figure 13. Ground-water recharge and discharge areas in the Great Salt Lake Basins study unit Data from Anderson and others, 1994. 


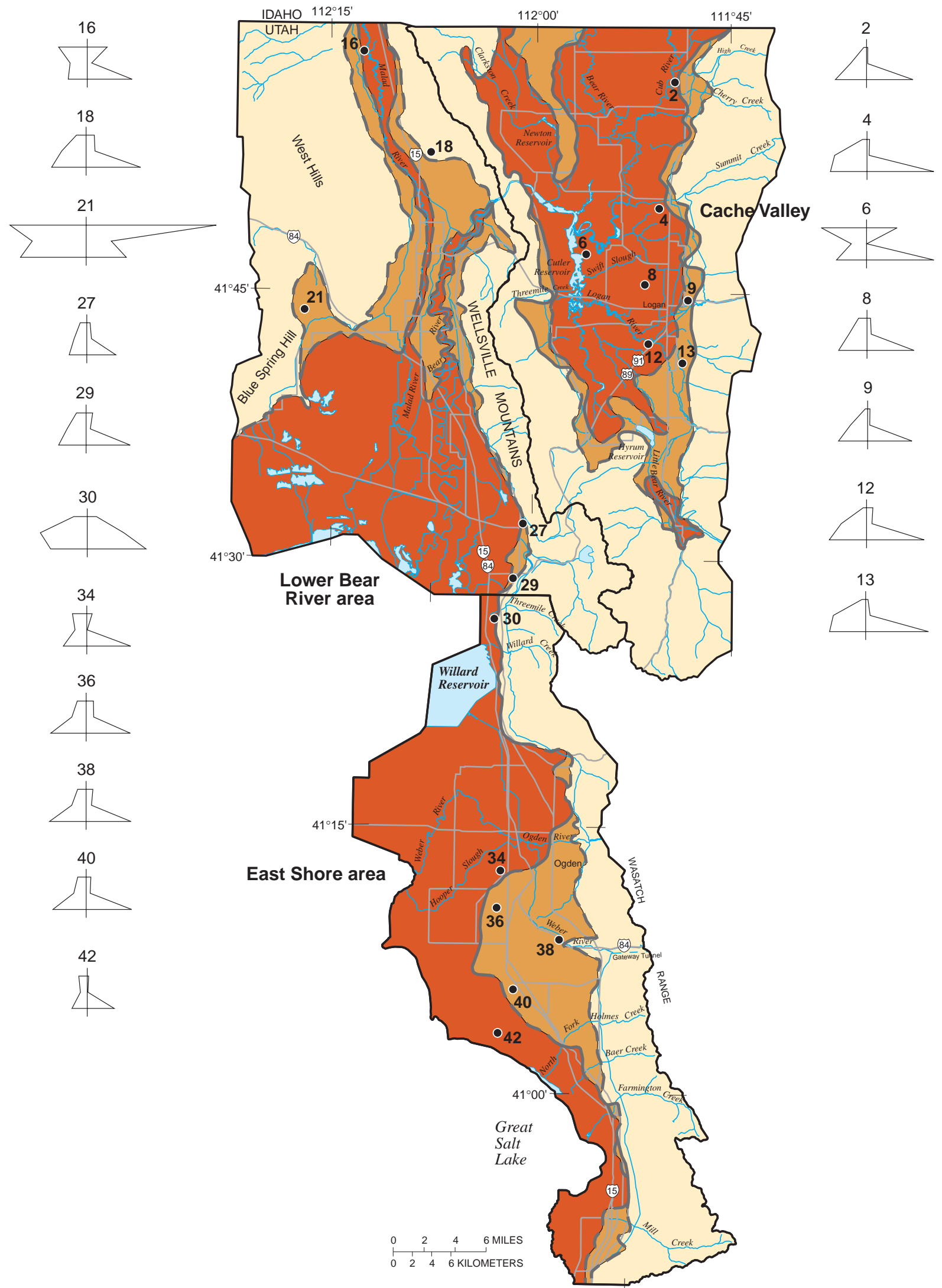

Figure 14. Chemical composition of selected ground-water samples from the principal basin-fill aquifer in the Great Salt Lake Basins study unit.

Data from Anderson and others, 1994. 


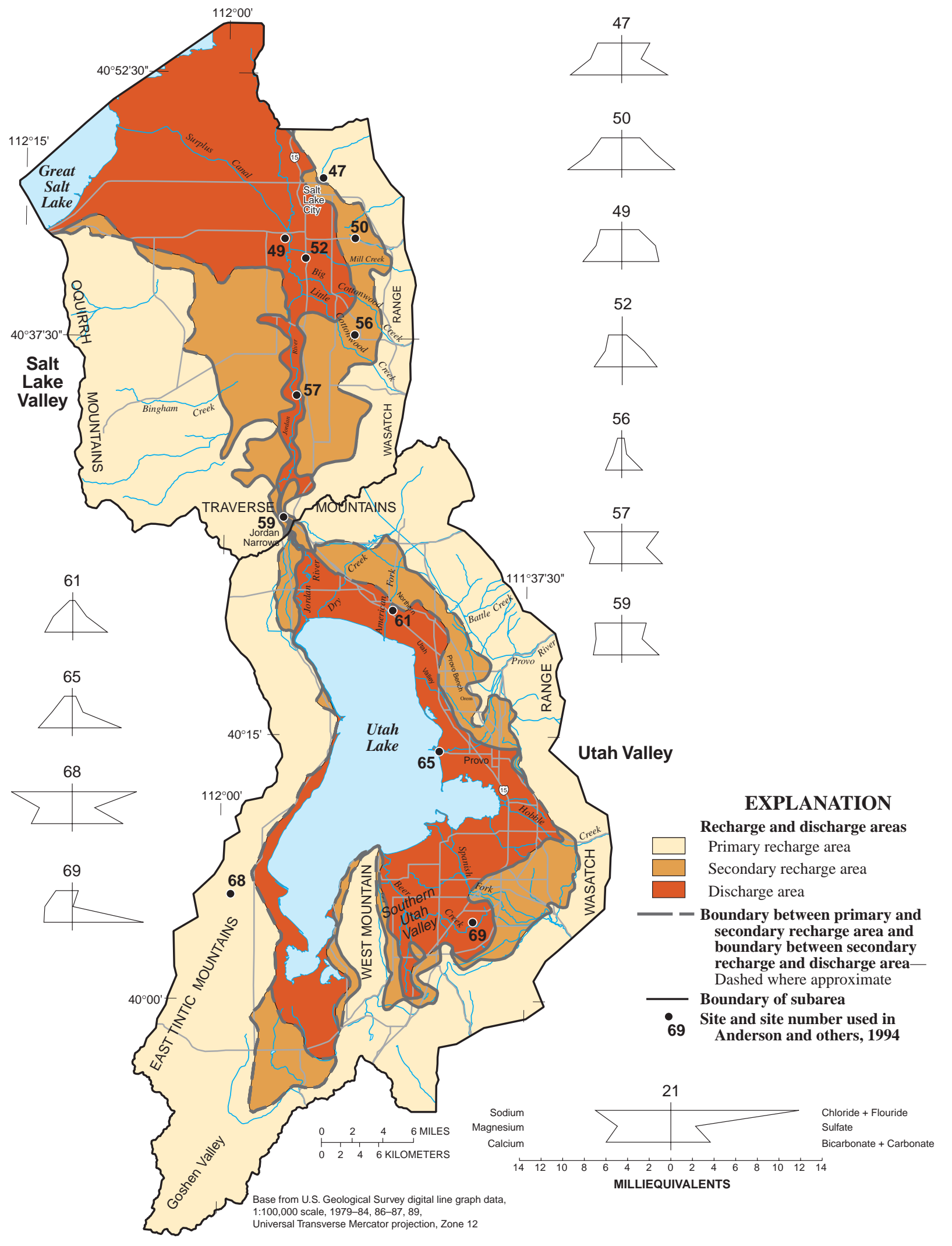

Figure 14. Chemical composition of selected ground-water samples from the principal basin-fill aquifer in the Great Salt Lake Basins study unit-Continued

Data from Anderson and others, 1994. 


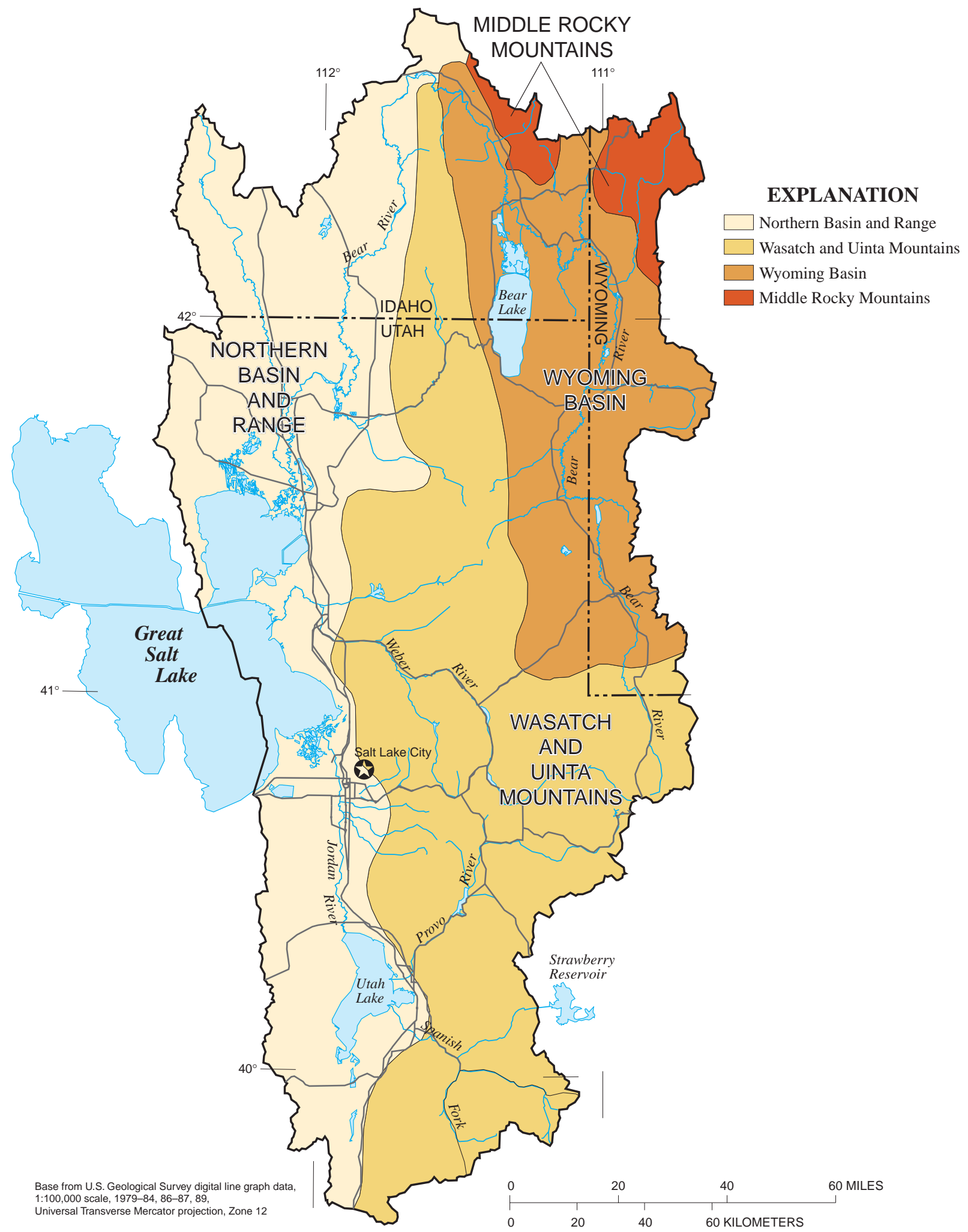

Figure 15. Ecoregions of the Great Salt Lake Basins study unit. Data from Omernik, 1987. 
and dry or poorly developed soils. It is used extensively for grazing and some irrigated agriculture. The smallest ecoregion, the Middle Rocky Mountains, covers only 3 percent in the far northeastern part of the Bear River basin and is primarily shrub and brush rangeland and forest.

\section{Land Use}

Human influences on the landscape, in association with waste by-product handling, affect the type, location, transport, and concentration of contaminants that occur in surface and ground water. Land-use/land-cover information is useful in examining the direct and indirect consequences of human influences on water quality by providing information on the possible causal factors related to water-quality observations. Several land-use/landcover surveys have been done in the GRSL study unit with information derived at different scales and quality. The first basin-wide comprehensive study was done by the USGS in the mid-1970s (GIRAS) (Anderson and others, 1976). Additional land-use/land-cover programs covering areas of the GRSL study unit include water-related land-use mapping by the Utah Department of Natural Resources (1995), the Utah GAP Analysis (U.S. Geological Survey, 1996), an update to the residential areas in the 1970s GIRAS data using 1990 Census data (Hitt, 1994a), and a national effort to use satellite data to define multiresolution land-cover characteristics (MRLC) (Multiresolution Land-Cover Characteristics Consortium, 1994).

The updated GIRAS data indicate that rangeland covers 48 percent of the study unit and that forest and agricultural land covers 22 and 18 percent, respectively (Hitt, 1994a). Urban land use accounted for 4 percent of the total land use in the study unit, and the remaining 8 percent was distributed between wetlands ( 4 percent), water ( 3 percent), and barren lands (1 percent) (fig. 16).

The Bear River basin has the largest amount of agricultural land in the study unit, with most of it located in the area downstream from Bear Lake. Upstream from Bear Lake, the Bear River basin is composed primarily of rangeland. Rangeland is predominant in the upper part of the Weber River basin but land use changes to a mixture of urban and agricultural land about $10 \mathrm{mi}$ upstream from the mouth of the Weber River at Great Salt Lake. In the Utah Lake basin, the Provo River drainage is dominated by rangeland and forest but changes to primarily urban land use about $5 \mathrm{mi}$ upstream of the mouth of the Provo River at Utah Lake. Agriculture also is the primary land use along the southeastern and southern shores of Utah Lake.

Most urban development in the GRSL study unit lies along an 80-mi stretch of the Wasatch Front that extends from Provo on the south to Ogden on the north (fig. 16), with about 85 percent of the total population of Utah living within this area. The Jordan River basin contains the largest urbanized area along the Wasatch Front, although the Ogden and Provo areas also contain substantial urban areas. Urban land use, as used in this report, includes residential, commercial, and industrial areas, as well as cemeteries, golf courses, airports, roadways, and railroads.

\section{Water Use}

Irrigation is the primary use of water in the GRSL study unit (table 2). During 1995, irrigation for agriculture accounted for an estimated 92 percent of all water use in the Bear River drainage, 82 percent in the Weber River drainage, and 70 percent in the Utah Lake/Jordan River drainage (fig. 17). Water use for public supply was estimated at 4 percent in the Bear River drainage, 16 percent in the Weber River drainage, and 26 percent in the Utah Lake/Jordan River drainage. Surface water is the principal source of water for irrigation and ground water is the principal source for public supply (U. S. Geological Survey, 1995).

Total water use for the GRSL study unit in 1995 was estimated to be $2,797 \mathrm{Mgal} / \mathrm{d}$ (table 2). About 2,379 Mgal/d (85 percent) of this total were surfacewater withdrawals and $418 \mathrm{Mgal} / \mathrm{d}$ (15 percent) were ground-water withdrawals. Irrigation accounted for about 2,130 Mgal/d in surface-water withdrawals and $139 \mathrm{Mgal} / \mathrm{d}$ in ground-water withdrawals. Public supply was estimated at $193 \mathrm{Mgal} / \mathrm{d}$ and $240 \mathrm{Mgal} / \mathrm{d}$ for surface- and ground-water withdrawals, respectively.

The population served by public-supply water in the GRSL study unit in 1995 was estimated at 1,658,670 (table 3 ). The population served by a nonpublic water source (self-supplied) was estimated at 39,080. Most self-supplied water came from wells. 


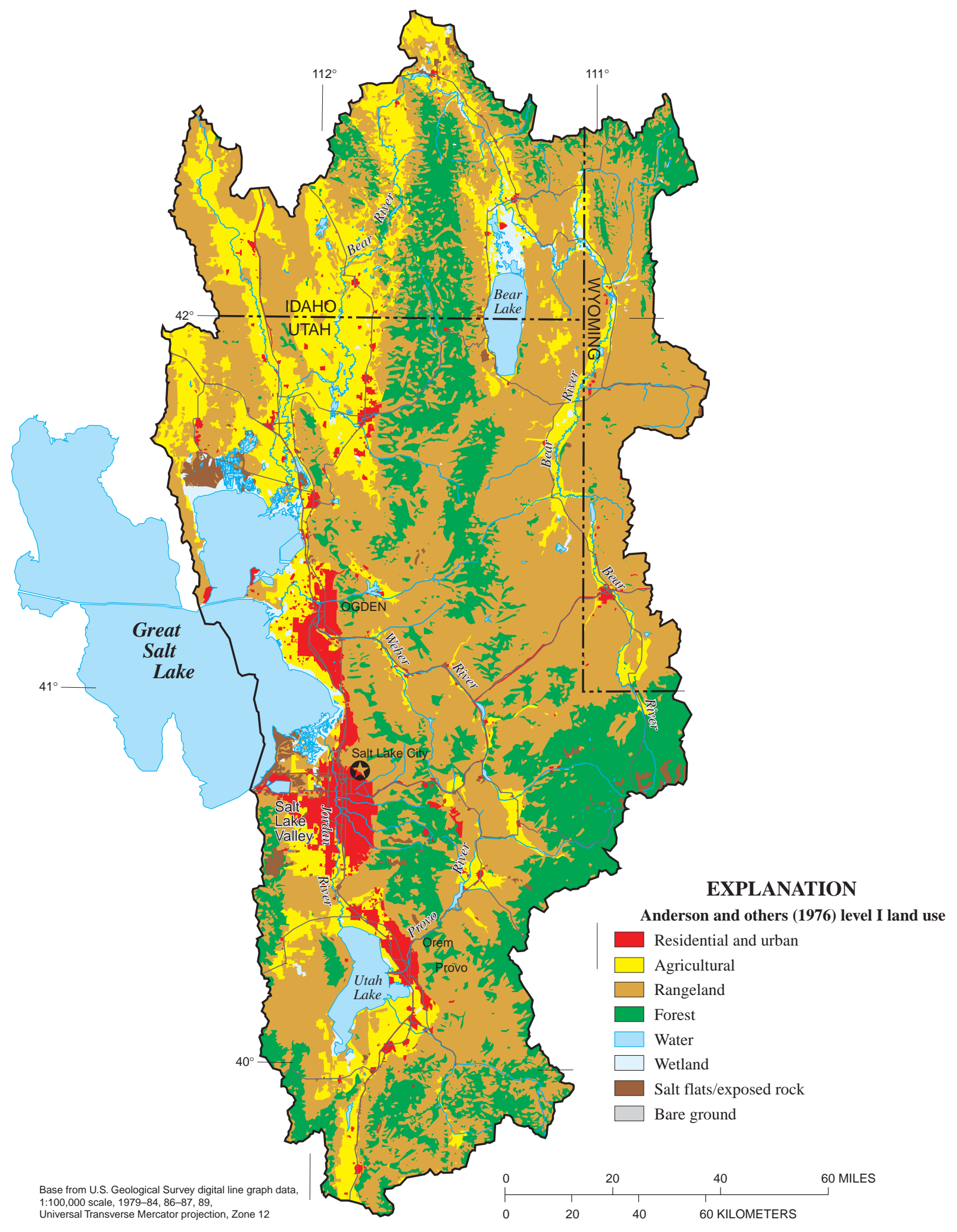

Figure 16. Generalized land use in the Great Salt Lake Basins study unit, GIRAS level I. Data from Hitt, 1994a. 
Table 2. Water use in the Great Salt Lake Basins study unit, 1995

\begin{tabular}{l|c|c|c|c|c}
\hline \multirow{2}{*}{ Type of water use } & \multicolumn{2}{|c|}{ Estimated surface-water withdrawal } & \multicolumn{2}{|c|}{$\begin{array}{c}\text { Estimated ground-water } \\
\text { withdrawal }\end{array}$} & $\begin{array}{c}\text { Total withdrawal } \\
\text { (million gallons per } \\
\text { day) }\end{array}$ \\
\cline { 2 - 5 } & $\begin{array}{c}\text { Million gallons } \\
\text { per day }\end{array}$ & Percent & $\begin{array}{c}\text { Million gallons } \\
\text { per day }\end{array}$ & Percent & 2,269 \\
\hline Irrigation & 2,130 & 94 & 139 & 6 & 433 \\
Public supply & 193 & 45 & 240 & 55 & 95 \\
Other ${ }^{1}$ & 56 & 59 & 39 & 41 & 2,797 \\
Total & 2,379 & 85 & 418 & 15 & \multicolumn{1}{c}{${ }^{1}$ Other includes self-supplied domestic, self-supplied commercial, self-supplied industrial, and mining, fossil fuel, and livestock/animal specialties. }
\end{tabular}

Table 3. Population served by public-supply water and selfsupply water, Great Salt Lake Basins study unit, 1995

\begin{tabular}{lrr}
\hline \multicolumn{1}{c}{ Basin } & $\begin{array}{c}\text { Public } \\
\text { supply }\end{array}$ & $\begin{array}{c}\text { Self } \\
\text { supply }\end{array}$ \\
\hline Bear River basin & 129,870 & 21,500 \\
Weber River basin & 403,370 & 2,720 \\
Utah Lake/Jordan River basin & $1,125,430$ & 14,860 \\
Total & $1,658,670$ & 39,080 \\
\hline
\end{tabular}

\section{STUDY DESIGN}

The National Water-Quality Assessment program study unit activities are scheduled on a rotational basis. The first 20 study units were initiated in 1991, the next 15 in 1994, and the last 16, which included the GRSL study unit, in 1997 (fig. 18). The initial cycle for each study unit is 10 years with the first 2 years devoted to planning, study design, analysis of existing data, and preparation for data collection. The next 3 years are used for intensive data collection and preparation of interpretative reports. The datacollection phase is followed by a 5-year period for completion of reports and limited low-level assessment activities. Subsequent cycles for a specific study unit require a re-examination of the study unit and a redefinition of the important water-quality issues that affect that study unit. The new study is designed to address those new water-quality issues by using data gathered during the first study cycle and incorporating improvements in sampling and data interpretation.
During the first cycle of NAWQA study units, efforts were focused on defining the occurrence and distribution of natural and anthropogenic constituents in the water column, bed sediment and tissue, and ground water, and in examining biological communities associated with the water-column sampling sites. Each component of the first-cycle design phase is examined in this report. Surface- and ground-water components of the occurrence and distribution assessment are shown in figure 19.

\section{Surface Water}

\section{Environmental Stratification}

Physiography (fig. 6), lithology (fig. 7), and land-use (fig. 16) were used to develop a stratification diagram for surface-water activities (fig. 20). The headwaters of the Bear, Weber, and Provo (main tributary of Utah Lake) Rivers originate in the quartzite rocks in the Uinta Mountains of the Middle Rocky Mountains Physiographic Province, but each stream drainage has significantly different land uses in the lower reaches where they emerge in the Basin and Range Physiographic Province. Preliminary surfacewater sampling sites were selected to provide an evaluation of stream-water quality representative of the study unit while encompassing a range of conditions relevant to the National NAWQA design. Each sampling site or sample type serves a different purpose yet is selected to provide an integrated approach to study-unit investigations. 


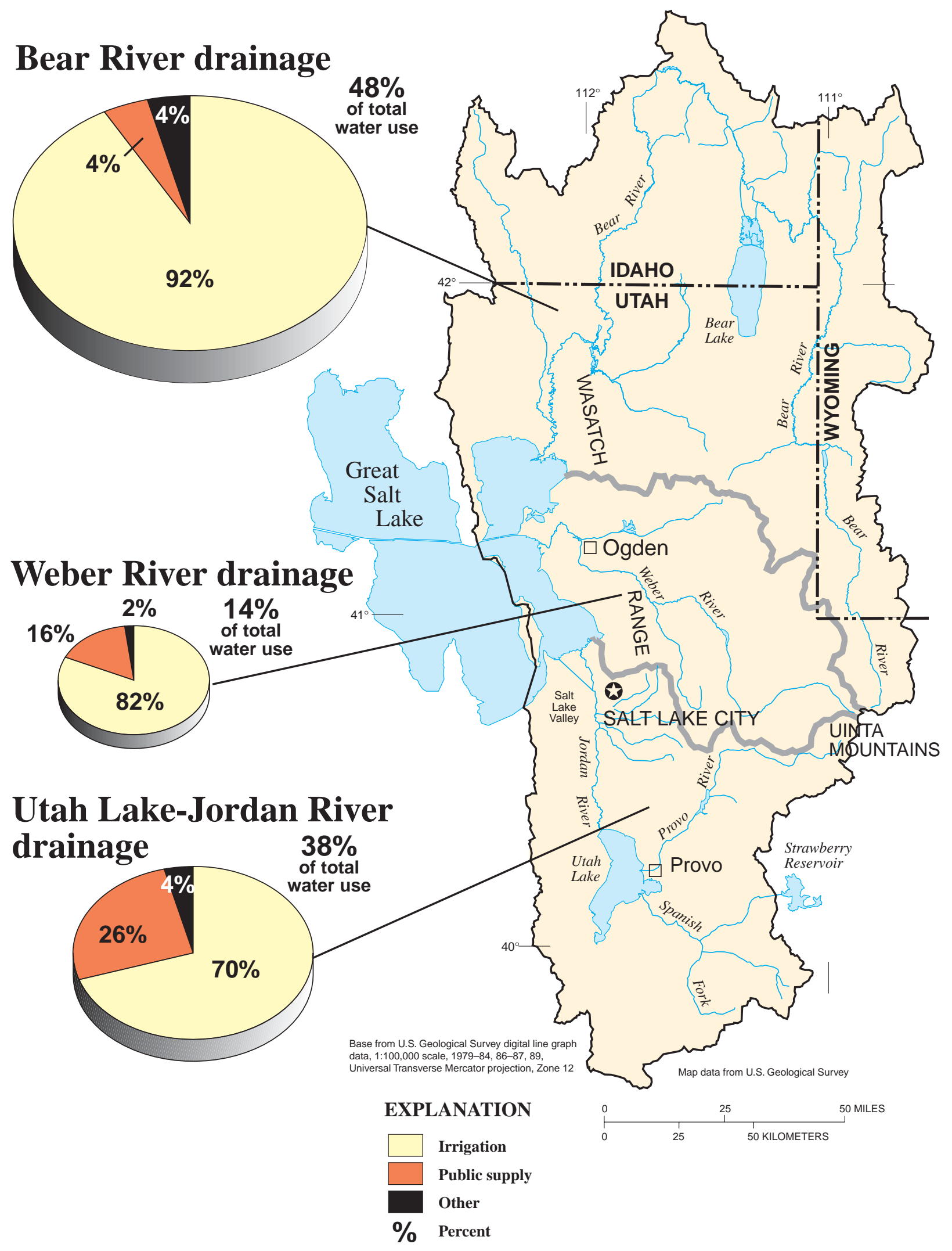

Figure 17. Percentage of total water use in the Great Salt Lake Basins study unit. 


\begin{tabular}{|c|c|c|c|c|c|c|c|c|c|c|c|c|c|}
\hline \multirow{2}{*}{$\begin{array}{l}\text { Study } \\
\text { units }\end{array}$} & \multicolumn{13}{|c|}{ Fiscal year } \\
\hline & \begin{tabular}{|l|l|}
19911992 \\
\end{tabular} & 1993 & 1994 & 1995 & 1996 & 1997 & 1998 & 1999 & 2000 & 2001 & 2002 & 2003 & 2004 \\
\hline \multicolumn{14}{|l|}{ Set 1} \\
\hline \multicolumn{14}{|l|}{ Set 2} \\
\hline Set 3 & & & & & & & & & & & & & \\
\hline
\end{tabular}

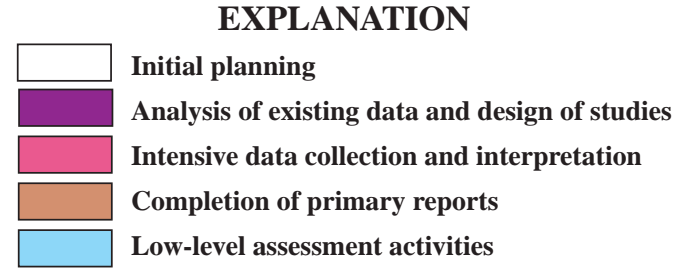

Figure 18. Timeline of National Water-Quality Assessment program activities.

Set 1 represents the 20 study units started in 1991; set 2 represents the 16 study units started in 1994; and set 3 represents the 16 study units started in 1997.

The stratification diagram and the population density of the study unit were used to select fixed surface-water monitoring sites for study to represent agricultural, rangeland, urban, and forested land-use drainages. These sites will provide data for assessing the natural and human-induced effects of land use.

\section{Basic-Fixed Sites}

Basic-fixed sites are surface-water monitoring sites that are established for monitoring during a 2-year period. The frequency of sampling is monthly, except during extreme flow periods when it is more frequent. Some parameters such as temperature and specific conductance may be continuously monitored during all or part of the 2-year period. Some of the basic-fixed sites were selected for more intensive sampling and are referred to as intensive-fixed sites. The intensive-fixed sites in the NAWQA study units are sampled monthly for dissolved pesticides and VOCs during a 1-year period. The GRSL fixed sites are shown in figure 21 and their land-use characteristics are listed in table 4.

Each basic-fixed site is also categorized as either an indicator or integrator for differing land uses or environmental settings. Indicator sites are located on streams near the mouths of drainages with similar land uses and physiographic conditions. Ideally, an indicator basin would be representative of one land use and one physiographic condition. Basins are chosen to be as large and as representative as possible while still encompassing primarily one environmental setting (Gilliom and others, 1995). In the GRSL study unit, mixed land-use settings necessarily were included in the drainage above the indicator site. Integrator stream-sampling sites are located downstream of drainage basins that are large and complex and often contain multiple environmental settings. Integrator sites in the GRSL study unit are located near the mouths of the three major streams, and the associated basins have multiple land uses and physical settings. About 95 percent of the drainage area of the study unit contributes runoff to the three integrator sites.

\section{Synoptic Studies}

Synoptic studies are short-term investigations of water quality during selected seasonal periods or during certain hydrologic conditions (Gilliom and others, 1995) and are used to characterize these conditions as they exist simultaneously throughout the study area. They are designed to improve spatial resolution for critical water-quality conditions and allow for identification of causative factors such as land use or other potential contaminant sources. 


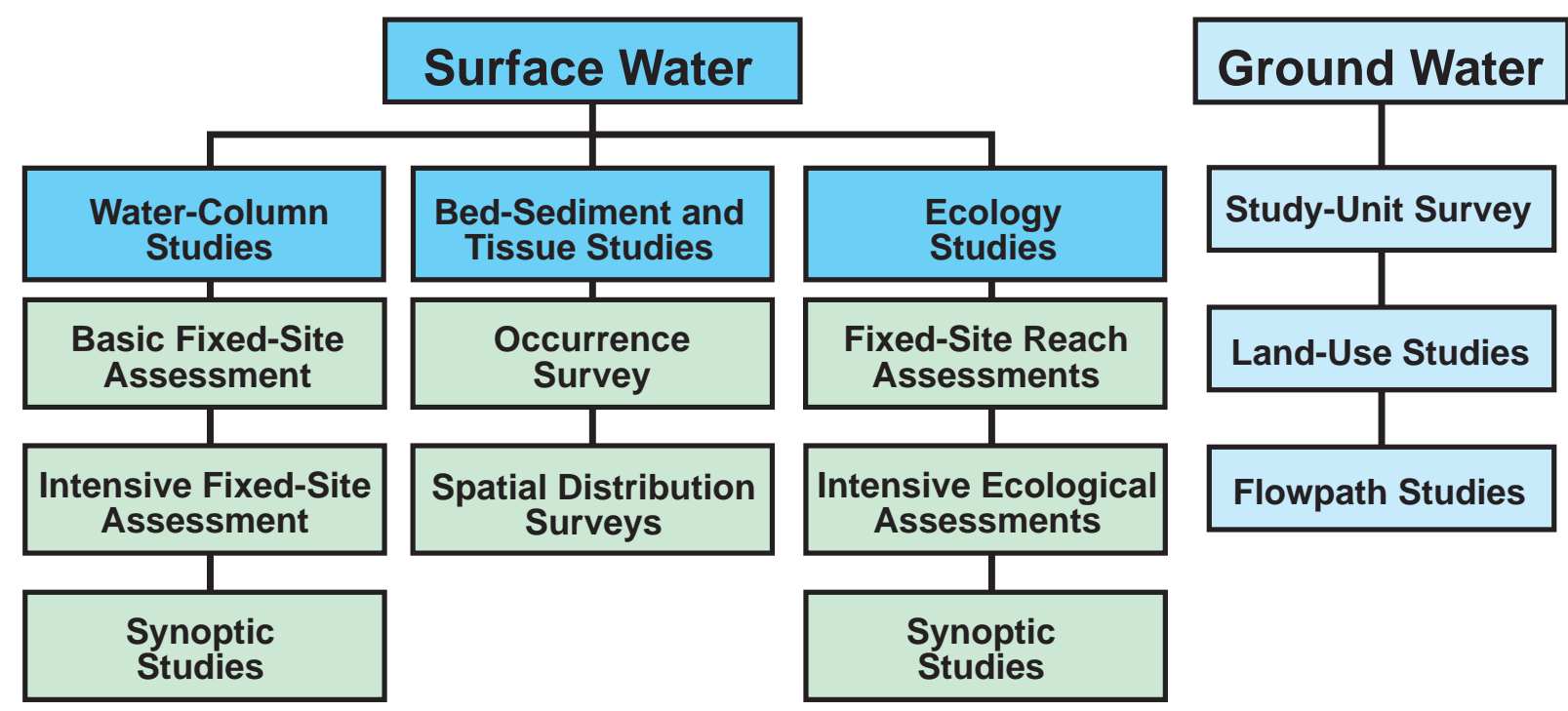

Figure 19. Occurrence and distribution assessment components for the first cycle of National Water-Quality Assessment program study units.

From Gilliom and others, 1995.

Synoptic studies in the GRSL study unit were conducted in the Salt Lake Valley urban area (nutrients, pesticides, and VOC occurrence), the Park City/Upper Weber River drainage area (trace metals and sediments), and the Bear River basin (nutrients).

Nutrients, pesticides, and VOCs in urban storm runoff also were sampled in the Salt Lake City metropolitan area.

Surface-water investigations for the GRSL study unit include water-column, bed-sediment and tissue, and ecological studies. Water-column studies include sampling at basic-fixed sites and intensive fixed-sites that each have a distinct purpose and sampling schedule. Synoptic sites were established for one or more samples to provide concurrent spatial coverage throughout a selected basin or area.

\section{Aquatic Habitat and Biota}

\section{Bed-Sediment and Tissue Sampling}

Bed sediment and tissues from fish and other aquatic animals were sampled to determine the occurrence and distribution of trace elements and hydrophobic organic contaminants in streams of the GRSL basins (Gilliom and others, 1995). Sites for the initial bed-sediment and tissue sampling in the GRSL (occurrence sites) include nine basic-fixed sites and three additional sites (table 5 and fig. 22) that were sampled during summer 1998. These data were used to provide an identification of the primary constituents (trace elements and hydrophobic organic contaminants) at these sites. A spatial distribution survey was done in summer 1999 to provide improved resolution in priority areas (table 5 and fig. 22). Priority areas for trace metals include the Park City/Upper Weber River basin, and for organic contaminants include the Jordan River.

\section{Ecological Studies}

Ecological studies of aquatic communities are used to help describe the water quality of streams through the use of indicator species, species diversity, and relative abundance (Gilliom and others, 1995). These studies began in the summer of 1999 and continued through summer 2001. Ecological studies include sampling of fish, macroinvertebrate, and algae communities and a habitat survey. Ten sites were 


\section{Great Salt Lake Basins Land-Use/Land-Cover Environmental Stratification}

Physiographic Province (Fenneman, 1931)

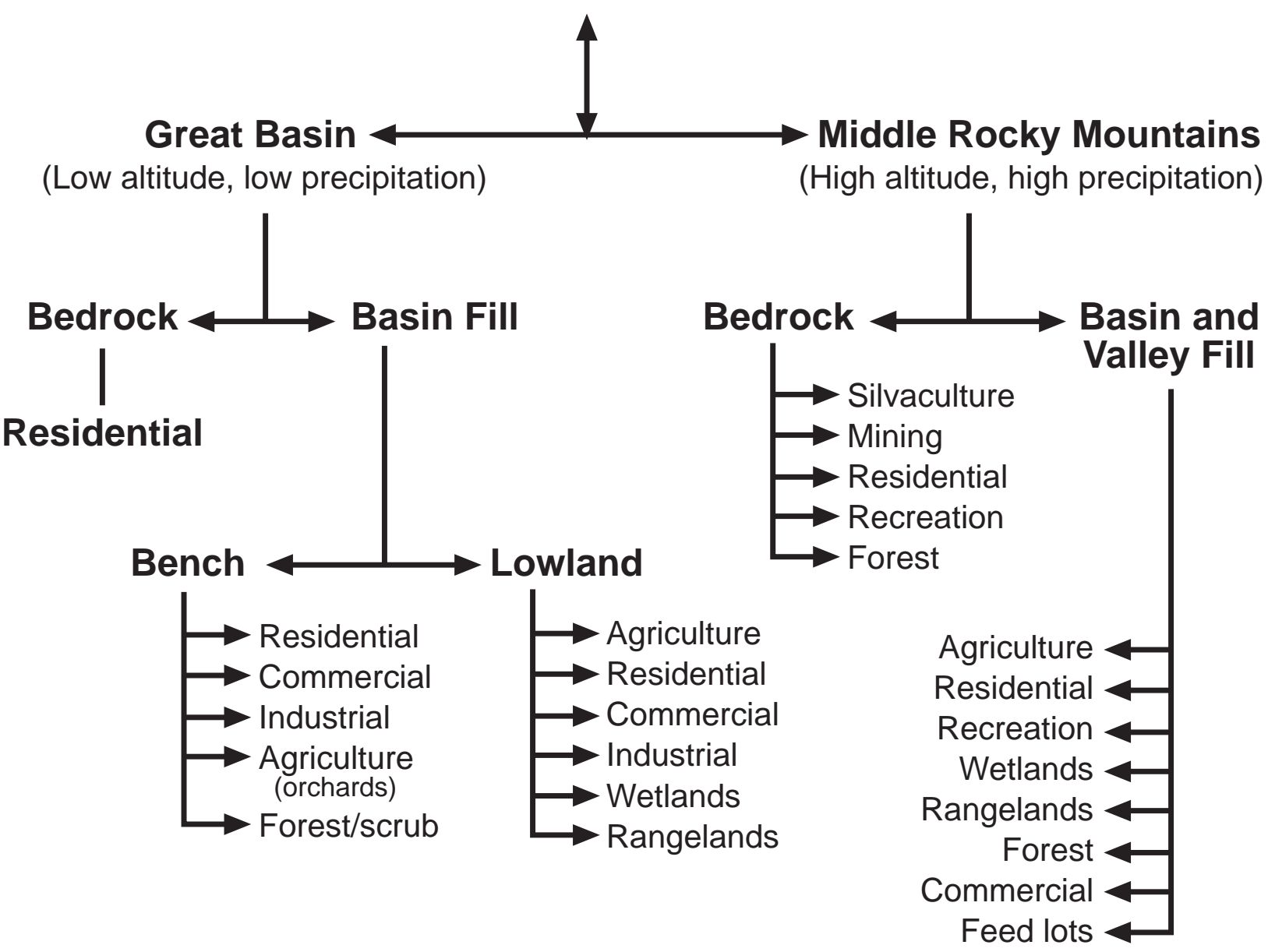

Figure 20. Environmental stratification for surface-water activities, Great Salt Lake Basins study unit. 


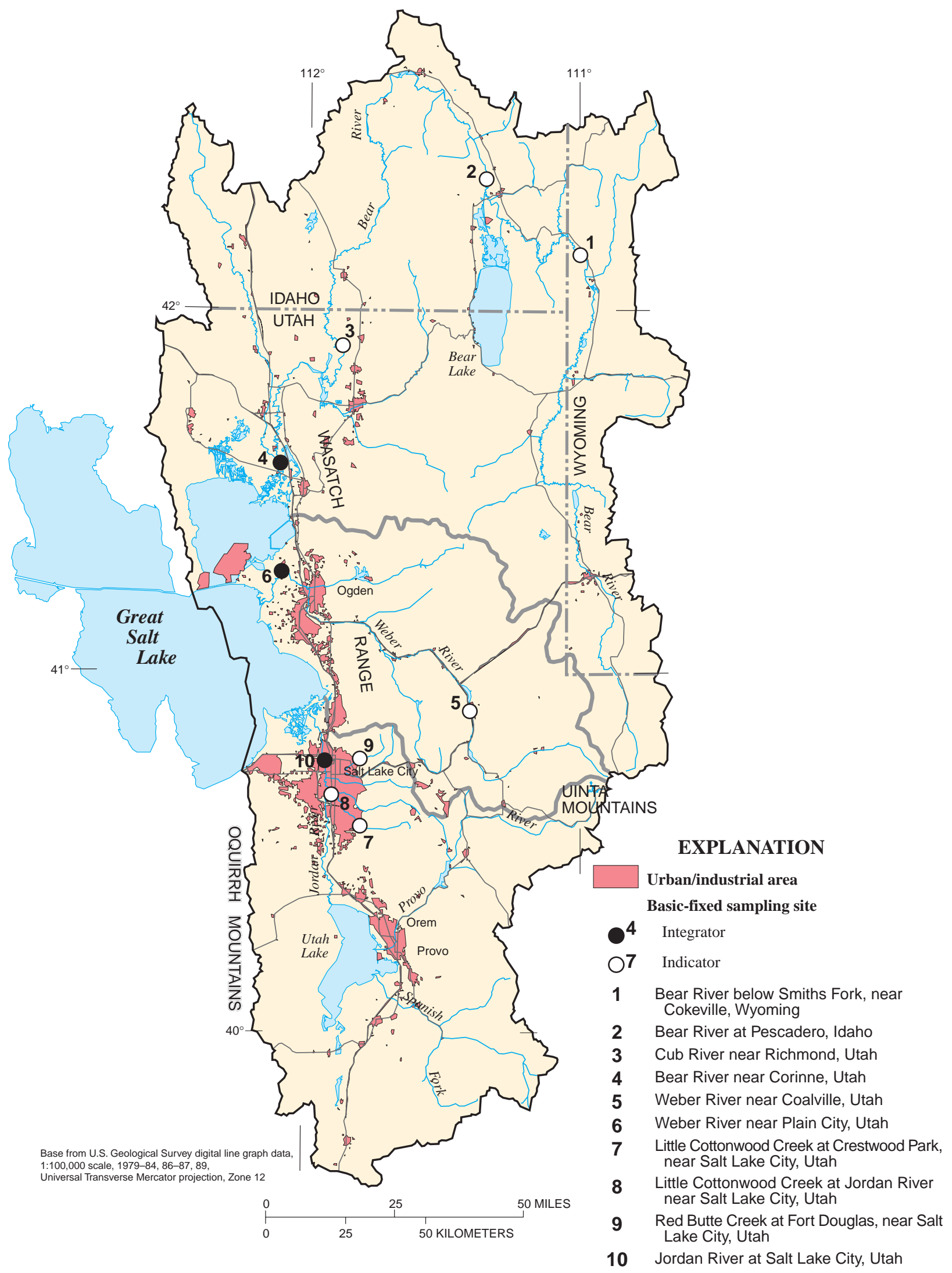

Figure 21. Location of basic-fixed surface-water monitoring sites for the Great Salt Lake Basins study unit. 
Table 4. Description of basic-fixed surface-water monitoring sites for streams in the Great Salt Lake Basins study unit

[<, less than; B, Basin and Range; NBR, Northern Basin and Range; N/A, not applicable; M, Middle Rocky Mountains; WYB, Wyoming Basin; WUM, Wasatch and Uinta mountains]

\begin{tabular}{|c|c|c|c|c|c|c|c|c|c|c|c|c|c|}
\hline \multirow{2}{*}{$\begin{array}{c}\text { Site } \\
\text { num- } \\
\text { ber } \\
\text { (fig. } \\
18 \text { ) }\end{array}$} & \multirow[b]{2}{*}{$\begin{array}{c}\text { Basic-fixed site type and } \\
\text { name }\end{array}$} & \multirow{2}{*}{$\begin{array}{l}\text { Drainage } \\
\text { area } \\
\text { (square } \\
\text { miles) }\end{array}$} & \multicolumn{6}{|c|}{$\begin{array}{l}\text { Land use }^{1} \\
\text { (percent) }\end{array}$} & \multirow{2}{*}{ 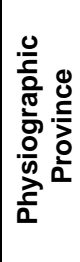 } & \multirow{2}{*}{$\begin{array}{l}\text { 응 } \\
\text { ㅎํㅇ } \\
\text { ய }\end{array}$} & \multirow{2}{*}{$\begin{array}{l}\frac{0}{0} \\
\frac{0}{0} \\
\frac{0}{\pi} \\
\frac{0}{0} \\
\frac{5}{2}\end{array}$} & \multirow{2}{*}{ 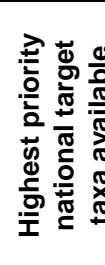 } & \multirow{2}{*}{ 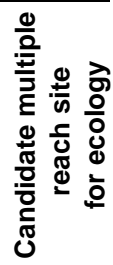 } \\
\hline & & & 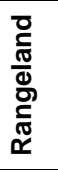 & 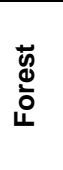 & $\begin{array}{l}00 \\
\frac{0}{3} \\
\frac{1}{3} \\
\frac{0}{2} \\
\frac{0}{4}\end{array}$ & $\begin{array}{l}\text { 들 } \\
\text { 인 }\end{array}$ & $\begin{array}{l}\frac{2}{\frac{\pi}{\pi}} \\
\frac{\pi}{\pi} \\
3\end{array}$ & 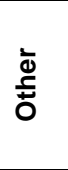 & & & & & \\
\hline & Integrator sites: & & & & & & & & & & & & \\
\hline 4 & $\begin{array}{l}\text { Bear River near Corinne, } \\
\text { Utah }\end{array}$ & 7,065 & 52 & 21 & 23 & 1.0 & 1.3 & $<2$ & B & NBR & Alfalfa & Carp & Yes \\
\hline 6 & $\begin{array}{l}\text { Weber River near Plain CIty, } \\
\text { Utah }\end{array}$ & 2,072 & 60 & 30 & 6.7 & 2.7 & .7 & $<1$ & B & NBR & Alfalfa & Carp & No \\
\hline 10 & $\begin{array}{l}\text { Jordan River at Salt Lake } \\
\text { City, Utah }\end{array}$ & 3,508 & 44 & 31 & 14 & 5.2 & $<1$ & 5.2 & B & NBR & N/A & Carp & No \\
\hline & Indicator sites: & & & & & & & & & & & & \\
\hline 1 & $\begin{array}{l}\text { Bear River below Smiths } \\
\text { Fork, near Cokeville, } \\
\text { Wyoming }\end{array}$ & 2,444 & 71 & 19 & 8.4 & $<1$ & $<1$ & $<1$ & M & WYB & Alfalfa & Carp & No \\
\hline 2 & $\begin{array}{l}\text { Bear River at Pescadero, } \\
\text { Idaho }\end{array}$ & 3,699 & 63 & 19 & 11.2 & $<1$ & 2 & 4.3 & M & WYB & Alfalfa & Carp & No \\
\hline 3 & $\begin{array}{l}\text { Cub River near Richmond, } \\
\text { Utah }\end{array}$ & 222 & 27 & 34 & 37 & 1.2 & $<1$ & $<1$ & B & NBR & Alfalfa & Carp & Yes \\
\hline 5 & $\begin{array}{l}\text { Weber River near Coalville, } \\
\text { Utah }\end{array}$ & 427 & 36 & 53 & 8.6 & 1.4 & $<1$ & $<1$ & M & WUM & Alfalfa & Carp & No \\
\hline 7 & $\begin{array}{l}\text { Little Cottonwood Creek at } \\
\text { Crestwood Park, at Salt } \\
\text { Lake City, Utah }\end{array}$ & 36 & 33 & 52 & 0 & 7.2 & $<1$ & 6.9 & $M$ & WUM & N/A & Trout & No \\
\hline 8 & $\begin{array}{l}\text { Little Cottonwood Creek at } \\
\text { Jordan River, near Salt } \\
\text { Lake City, Utah }\end{array}$ & 45 & 28 & 42 & $<1$ & 23 & 0 & 6.3 & B & NBR & N/A & Carp & Yes \\
\hline 9 & $\begin{array}{l}\text { Red Butte Creek, at Fort } \\
\text { Douglas, near Salt Lake } \\
\text { City, Utah }\end{array}$ & 7.21 & 93 & 6.9 & 0 & 0 & $<1$ & 0 & $M$ & WUM & N/A & Trout & Yes \\
\hline
\end{tabular}

selected to represent a variety of habitat conditions in the GRSL that result from different land uses and water-quality conditions throughout the study unit (table 6 and fig. 22). The sites coincide with the surface-water basic-fixed sites. Four sites were selected for sampling in multiple years to assess between-year variability in biological communities. The selected sites represent a variety of land use conditions: urban, agricultural, reference, and mixed land use. Multiple reaches were sampled at three of these sites to assess within-stream variability of biological communities. These three sites represent urban, agricultural, and reference land uses.

\section{Synoptic Studies}

Biological synoptic studies were planned to examine selected biological communities in detail. Synoptic studies were planned for urban streams along the Wasatch Front, for developing watersheds in the upper Weber River basin, and for the Bear River basin. All biological synoptic studies were coordinated with water-quality synoptic studies that were conducted in the same area. 
Table 5. Sites selected for occurrence survey to identify contaminants in bed sediment and fish tissue, and subset of sites for special sampling to determine presence of endocrine disrupters in fish tissue, Great Salt Lake Basins study unit

[STE, sediment trace elements; SO, sediment organics; FTE, fish trace elements; FO, fish organics; ED, endocrine disrupters; WYB, Wyoming Basin; NBR, Northern Basin and Range; WUM, Wasatch and Uinta Mountains; SNE, site not established]

\begin{tabular}{lccccccc}
\hline \multicolumn{1}{c}{ Site Name } & USGS Site & Ecoregion & STE & SO & FTE & FO & ED \\
\hline Bear River below Smiths Fork, near Cokeville, Wyoming & 10038000 & WYB & X & X & X & X & \\
Cub River near Richmond, Utah & 10102200 & NBR & X & X & X & X & \\
Bear River near Corinne, Utah & 10126000 & NBR & X & X & X & X & X \\
Weber River near Coalville, Utah & 10130500 & WUM & X & X & X & X & \\
Weber River near Plain City, Utah & 10141000 & NBR & X & X & X & X & X \\
Little Cottonwood Creek at Crestwood Park at Salt Lake City, Utah & 10167800 & WUM & X & X & X & X & \\
Little Cottonwood Creek at Jordan River at Salt Lake City, Utah & 10168000 & NBR & X & X & X & X & \\
Red Butte Creek at Fort Douglas, near Salt Lake City, Utah & 10172200 & WUM & X & X & X & X & \\
Jordan River at Salt Lake City, Utah & 10171000 & NBR & X & X & X & X & \\
Bear River above Reservoir, near Woodruff, Utah & 10020100 & WYB & X & X & X & X & \\
Jordan River at Cudahy Lane at Salt Lake City, Utah & 10172600 & NBR & X & X & X & X & X \\
Jordan River at Utah Lake outflow, near Lehi, Utah & SNE & NBR & & & X & & X \\
\hline
\end{tabular}

\section{Ground Water}

A major ground-water-quality issue is the effect of urbanization and ground-water development on water quality. Increased withdrawal of ground water for public supply and irrigation has induced the movement of naturally occurring and anthropogenically affected poorer-quality ground water, both vertically and laterally. The water quality of aquifers used for public supply or in connection with aquifers used for public supply is a focus of the study-unit investigation.

The principal aquifers in the study unit include the deeper unconfined and confined parts of the unconsolidated basin-fill aquifers (fig. 12). Primary recharge areas have the greatest potential for transmitting contamination to the principal aquifers because of the predominance of coarse-grained sediments and the absence of confining layers within these areas. The coarse-grained sediments in the primary recharge areas typically have large hydraulicconductivity values, and ground water commonly moves rapidly from the surface down to the principal aquifer.
In secondary recharge areas, the greatest potential for surface contamination to reach the principal aquifer is near the boundary between the secondary and primary recharge areas. Near this boundary, confining layers in the basin fill are generally thinner than they are elsewhere in the secondary recharge areas, and the hydraulic gradient between the shallow aquifer and the principal aquifer is greater than that near the boundary between the secondary recharge and discharge areas. In discharge areas, the water moves upward from the principal aquifer; thus, there is little or no potential for contamination unless pumpage from the deeper aquifer is great enough to reverse the vertical gradient or a contaminant is heavier than water.

\section{Study-Unit Surveys}

Study-unit surveys in the GRSL study unit were designed to characterize the quality of water in the basin-fill aquifers that is most important for present and future uses in the area. The GRSL study unit groundwater resource has been stratified on the basis of physiography, lithology, and land use. The ground water in each of the categories was divided into 


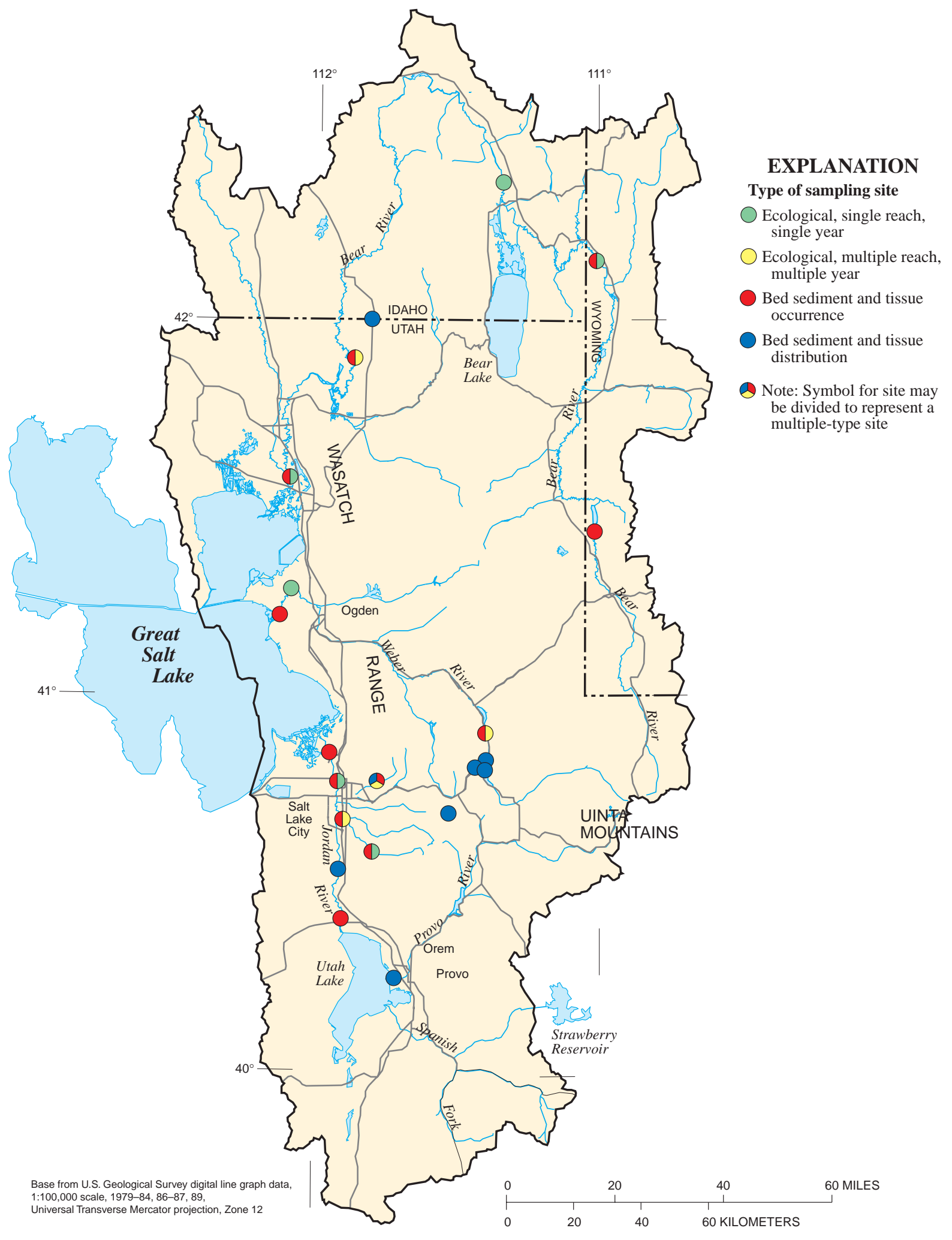

Figure 22. Location of bed-sediment, fish-tissue, and ecological sampling sites in the Great Salt Lake Basins study unit, 1999-2001. 
Table 6. Sites selected for ecological sampling and predominant habitat type expected at each site in the Great Salt Lake Basins study unit

[WYB, Wyoming Basin; NBR, Northern Basin and Range; WUM, Wasatch and Uinta Mtns; RTH, richest targeted habitat; DTH, depositional targeted habitat]

\begin{tabular}{lll}
\hline \multicolumn{1}{c}{ Site Name } & Ecoregion & $\begin{array}{c}\text { Predominant } \\
\text { habitat }\end{array}$ \\
\hline Bear River below Smiths Fork, near Cokeville, Wyoming & WYB & RTH \\
Bear River at Pescadero, Idaho & WYB & RTH \\
Cub River near Richmond, Utah & NBR & DTH \\
Bear River near Corinne, Utah & NBR & RTH \\
Weber River near Coalville, Utah & WUM & RTH \\
Weber River near Plain City, Utah & NBR & DTH \\
Little Cottonwood Creek at Crestwood Park near Salt Lake City, Utah & WUM & RTH \\
Little Cottonwood Creek at Jordan River, near Salt Lake City, Utah & NBR & DTH \\
Red Butte Creek at Fort Douglas, near Salt Lake City, Utah & WUM & RTH \\
Jordan River at Salt Lake City, Utah & NBR & DTH \\
\hline
\end{tabular}

aquifers in basin-fill deposits and consolidated rock (fig. 23). The basin-fill aquifers are the principal source of ground water for domestic and municipal supply and for irrigated agriculture in the area and are similar throughout the study unit. Unconfined, confined, and perched conditions occur in the basin-fill aquifers (fig. 12) (Hely and others, 1971).

The occurrence of the deeper unconfined aquifer corresponds with that of the primary recharge area in a subarea (fig. 13) and a lack of substantial confining layers. The depth to the water table is typically from 150 to $500 \mathrm{ft}$ below land surface. The deeper unconfined aquifer grades laterally into the deeper confined aquifer where overlain by confining layers. The land above the deeper unconfined aquifer has generally been undeveloped or is residential and commercial, but with an increase in population, residential and commercial land use has expanded. The deeper confined aquifer is recharged by the adjacent deeper unconfined aquifer and by the overlying shallow aquifer where allowed by vertical gradients and the discontinuity of confining layers. The aquifer is susceptible to contamination from water in the shallow unconfined aquifer that can be drawn downward by flow reversals resulting from withdrawals from wells.

The deeper unconfined and confined basin-fill aquifers in the primary and secondary recharge areas provide much of the ground water used for drinking water and irrigation within the study unit. Because of their importance as water sources and their susceptibility to contamination, these aquifers were selected to be examined by the study-unit surveys (fig. 13). The deeper unconfined and confined aquifers occur in all of the major valleys in the study unit, but aquifers in each valley are hydrologically separate from each other. The study-unit surveys include Cache Valley, the lower Bear River area, the East Shore area of Great Salt Lake, Salt Lake Valley, and Utah Valley where the extent of the primary and secondary recharge areas was mapped by Anderson and others (1994). Smaller valleys and mountain valleys were excluded because ground-water recharge areas have not been delineated.

Water from about 30 existing wells completed in the deeper unconfined aquifers and about 30 wells completed in the deeper confined aquifers in the secondary recharge areas was sampled as part of the study-unit surveys. Well locations were determined by a random well-selection procedure. The water was analyzed for major ions, selected pesticides and VOCs, nutrients, radon-222, and the stable isotopes oxygen18 and deuterium. The stable isotopes can be used to help determine sources of recharge. Tritium concentration also was analyzed to determine the approximate time of recharge. 


\section{CONCEPTUAL GROUND-WATER STRATIFICATION FOR THE GREAT SALT LAKE BASINS STUDY UNIT}

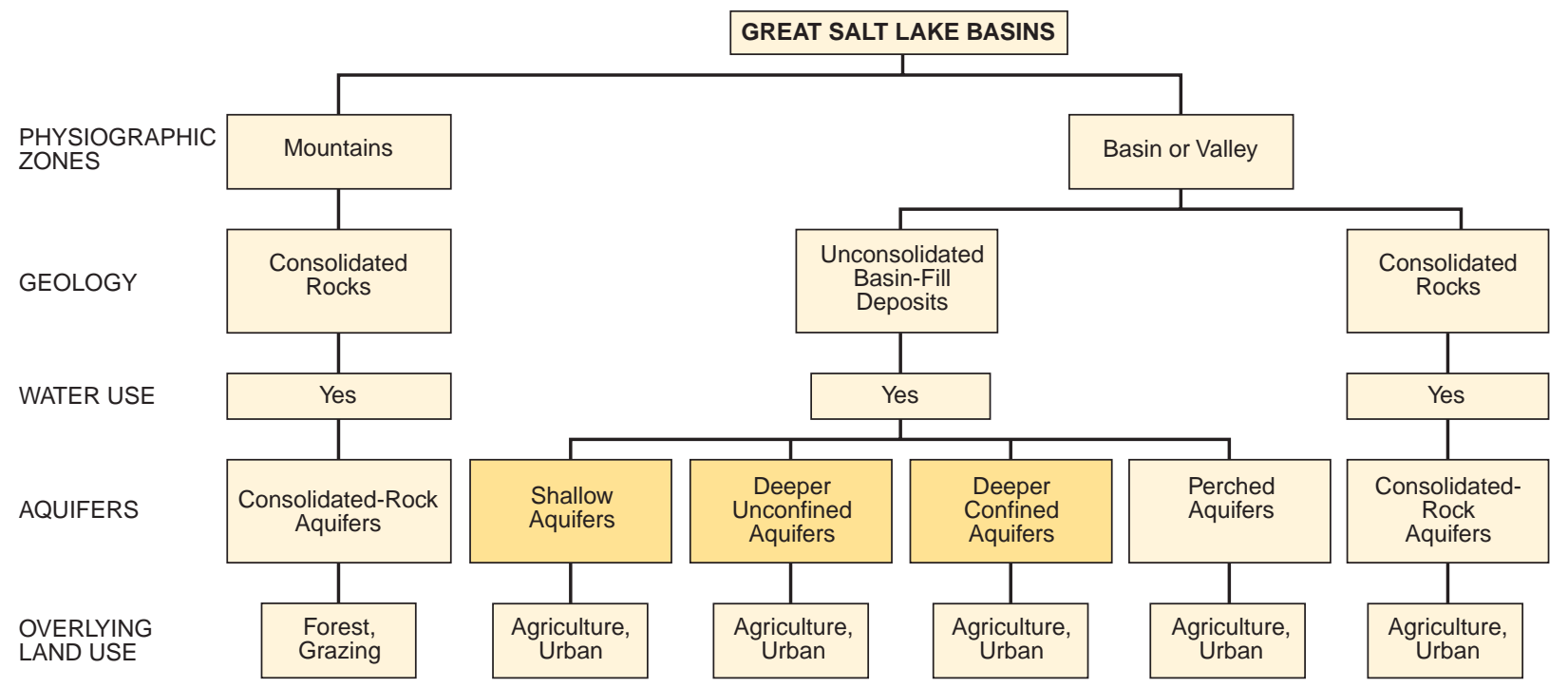

Agricultural land use includes crop cultivation and livestock grazing.

Shaded boxes represent aquifers to be studied that are susceptible to contamination from land-use practices.

Figure 23. Conceptual ground-water stratification for the Great Salt Lake Basins study unit. 


\section{Land-Use Studies}

How land use affects the quality of recently recharged ground water is being assessed in Salt Lake Valley, an urban area in the study unit. Water from sampled wells was analyzed at least once for major ions, selected pesticides and VOCs, nutrients, radon222 , and the stable isotopes oxygen-18 and deuterium. Water from selected wells was analyzed for tritium and/or chlorofluorocarbons to determine the approximate time of recharge. Samples from selected wells were analyzed for helium-3 in order to determine a time of recharge using the tritium/helium-3 method (Solomon and Cook, 2000, p. 411). Additional analysis was done to determine the reducing and oxidizing conditions of the aquifer.

\section{Shallow Ground-Water/Urban Land-Use Study}

Residential and commercial development of about $80 \mathrm{mi}^{2}$ that primarily replaced undeveloped and agricultural areas occurred in Salt Lake Valley from 1963 to 1994 . The shallow aquifer underlying recently developed residential and commercial areas in the secondary recharge area of Salt Lake Valley was selected for study (fig. 24) because a downward hydraulic gradient generally exists between it and the deeper confined aquifer. The deeper confined aquifer is used for public supply in the valley. The effects of human activities on the quality of shallow ground water in the recently developed areas could potentially affect the quality of water in the deeper confined aquifer. This study will provide a better understanding of water quality in the shallow aquifer and how it is affected by human activities related to development.

About 30 monitoring wells were installed with initial locations determined by a computerized, stratified random selection process. The actual well locations determined by the random selection process may have changed because of access and other constraints. Depth to ground water was considered in the placement of monitoring wells. Wells drilled with a hollow-stem auger rig were limited to about $150 \mathrm{ft}$ in depth. An air rotary drill rig was required when greater depths to the water table or large cobbles or boulders were encountered. To the extent possible, wells were installed on public land to increase the probability of future resampling. A subset of five monitoring wells were sampled more than once to evaluate seasonal variations in water quality. Water-level fluctuations were determined from monthly water-level measurements.

\section{Deeper Ground-Water/Urban Land-Use Study}

The principal basin-fill aquifer in Salt Lake Valley is used for drinking water and corresponds to the primary and secondary recharge areas and discharge area (fig. 24). Land development for residential and commercial use has left few undeveloped areas that include the recharge areas and basin-fill deposits. VOCs, such as tetrachloroethane (PCE), and an increase in chloride concentration, which may be attributed to the application of road salt, have been detected in water pumped by public-supply wells completed in the deep unconfined and confined aquifers. A study of the quality of water from the principal aquifer provides information on where recently recharged water is reaching the deeper aquifers and if man-made compounds occur in ground water pumped for public supply.

Water from about 30 public-supply wells was sampled during this study. The wells were selected on the basis of how much water is withdrawn from them and how they are distributed throughout the valley. For statistical purposes, a minimum spacing of 1 kilometer was used between sampled wells. The information from this study was used to identify areas with relatively recently recharged water that are susceptible to human-induced changes in water quality. Changes in the water quality of the deeper aquifers during a 10year period from 1989-91 to 1999-2001 were determined from dissolved-solids concentrations.

\section{Trend Analysis from Sediment Cores}

Examination of water-quality trends can help us understand the influence of human activities on waterquality conditions, indicate the effectiveness of environmental regulations, and provide a warning of additional degradation of water quality in the future. Sediment cores can help determine water-quality trends throughout historic and geologic time periods. As elements or compounds that are associated with sediments are deposited on the bottom of water bodies, they create a continuous record of their occurrence through time. 


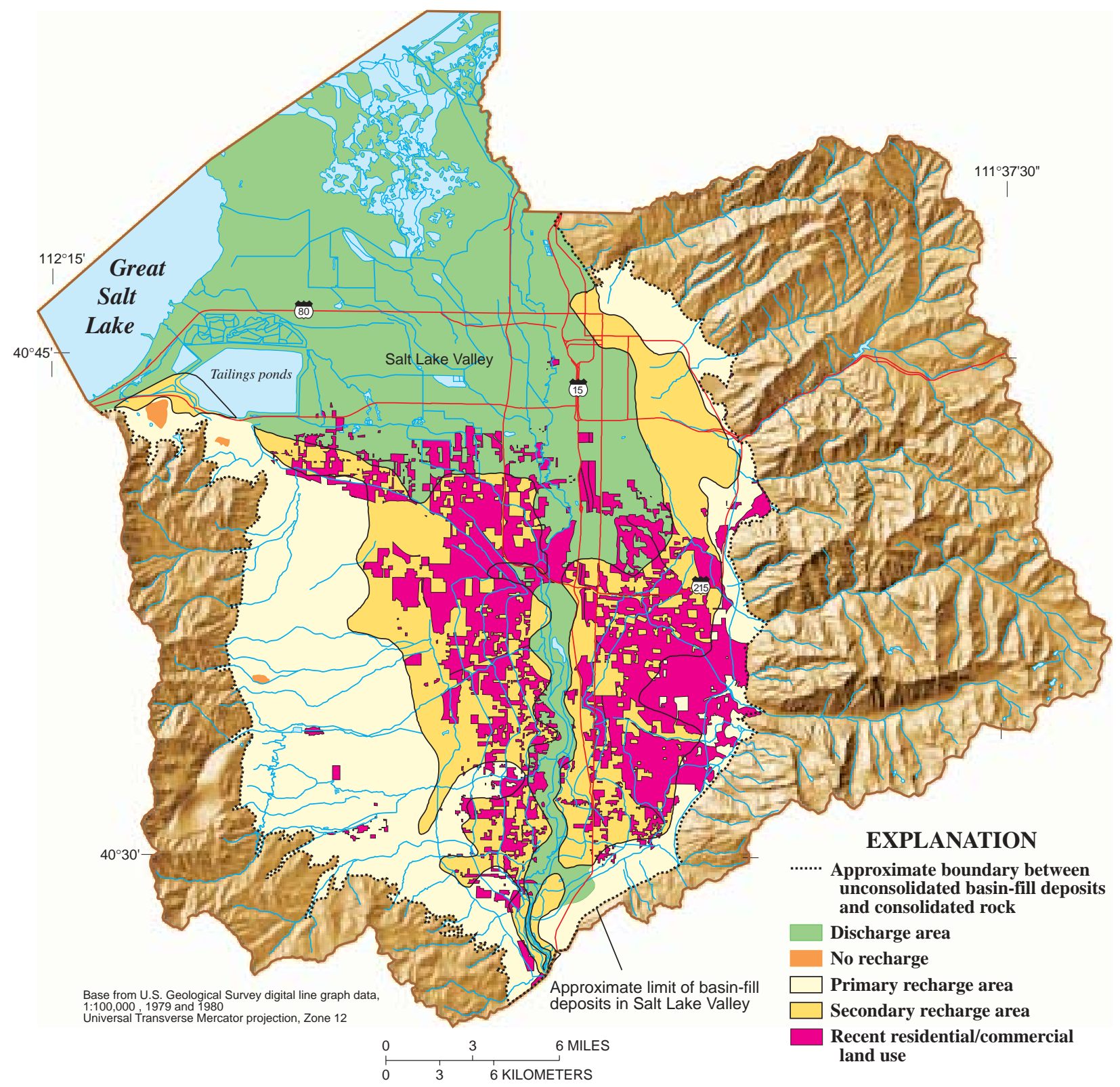

Figure 24. Areas of recent residential/commerical development and ground-water recharge in Salt Lake Valley, Utah. 
Two different studies of sediment cores have been undertaken in the GRSL study unit. USGS scientists Peter Van Metre and Edward Callendar collected cores from Farmington Bay of Great Salt Lake, Decker Lake (a small urban pond in Salt Lake City), and Red Butte Reservoir during March 1998 as part of the NAWQA program. Cores also were collected from Bear Lake in June 1998 as part of the Western Lake Catchment Systems (LACS) studies within the USGS Global Change Program (fig. 25).

Cores collected along the Wasatch Front will help in the reconstruction of the history of contaminant flux from runoff and atmospheric deposition during the past several decades of urban and industrial growth. Red Butte Reservoir is expected to be representative of background levels of atmospheric deposition near urban areas because of its long history of protected land use in the watershed. Cores from Decker Lake and Farmington Bay will provide information on possible contaminants from industrial and urban land use in Salt Lake Valley. Cores from Bear Lake will provide information on possible contaminants from upstream or from tributaries of the lake. Upstream from Bear Lake, the drainage basin is affected primarily by agricultural and rangeland use.

\section{SUMMARY}

The Great Salt Lake Basins is 1 of 51 initial study units to be investigated under the U.S. Geological Survey's National Water-Quality Assessment (NAWQA) program. The results of the study-unit investigations will provide information to help understand and manage the water resources of the study unit and will be aggregated with equivalent information from other study units to assess regional and national-scale water-quality issues.

The Great Salt Lake Basins study unit is characterized by diverse topography, geomorphology, natural vegetation, geology, and climate. Altitude and types of vegetation range from barren mud flats and desert shrubs near the shore of Great Salt Lake at about 4,200 feet to areas above the timberline at 10,000 to 12,000 feet. The headwaters of the Bear, the Weber, and the Provo Rivers are in the western part of the Uinta Mountains, at the eastern edge of the study unit, at altitudes above 10,000 feet. The streams flow from their headwaters, through the broad valleys of the Uinta Mountains, and emerge through the Wasatch Range, discharging into Great Salt Lake.

As the three rivers emerge from the headwater areas, the natural factors that affect water quality generally are similar. In the lower altitudes west of the Wasatch Range, and, in lesser part, the areas east of and adjacent to the Wasatch Range, both human and natural factors differ considerably and affect the streams in different ways. The Bear and Weber Rivers primarily are affected by agriculture, including livestock, whereas the Jordan River primarily is affected by the metropolitan area of the Salt Lake Valley.

The Bear River, Weber River, and Utah LakeJordan River basins have headwaters that originate in Precambrian quartzite of the Uinta Mountains. At altitudes below about 5,200 feet, the rivers and Utah Lake are incised into sediments of post-Lake Bonneville age. The soils of the valleys in the upper altitudes of the three major drainage basins are developed from alluvial sediments on flood plains, alluvial fans, and footslope areas at the base of the mountains. The soils are generally well drained and contain more than 70 percent sand and silt. Quartzites and sandstones are the predominant parent material for the alluvium found in the upper valleys. In general, the arable lands of the basin have good water transmission properties and adequate moisture-holding capacity, which, with other favorable physical and chemical properties, make them well suited for irrigated agriculture.

The climate in the mountainous areas of the Great Salt Lake Basins study unit is characterized by wide ranges in temperature between summer and winter and between day and night. Average annual temperature ranges from 32 to $52^{\circ} \mathrm{F}$. Each of the basins in the study unit receives most of its precipitation as snow during the winter months and produces most of its annual runoff during the spring snowmelt periods. Normal annual precipitation ranges from 12 to 16 inches on the valley floors to more than 70 inches in the high mountain areas.

Total average annual surface-water discharge from the three river systems in the Great Salt Lake Basins study unit during 1931-76 was 2.98 million acre-feet per year. Of this total, about 62 percent is discharged by the Bear River basin, 23 percent by the Weber River basin, and 15 percent by the Utah Lake/Jordan River basins. 


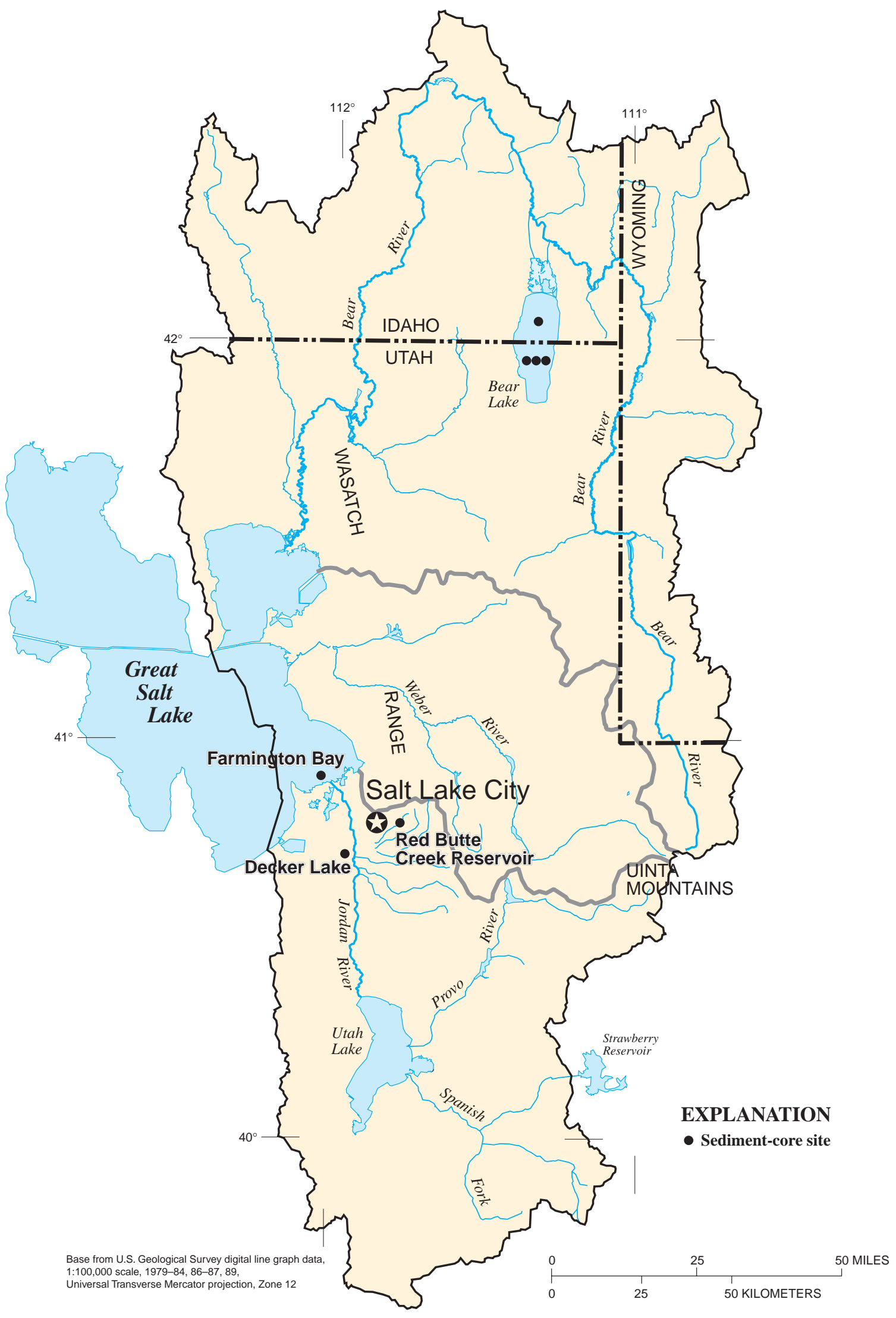

Figure 25. Sites where sediment cores were collected for trend analysis during 1998, Utah and Idaho. 
The ground-water systems in the Great Salt Lake Basins study unit occur mainly within unconsolidated basin-fill material. The basin-fill deposits are the principal source of ground water for domestic and municipal supply and for irrigated agriculture in the study area. The basin-fill aquifers have been classified into two types: shallow unconfined aquifers and principal aquifers. Each principal aquifer includes the confined aquifer system and the unconfined aquifer along the mountain front. Water quality of aquifers used for public supply and believed to be susceptible to contamination from organic constituents will be a focus of the study-unit investigations.

Nonpoint sources of contaminants, primarily nutrients from agricultural activities, are the major impediments to use of streams and lakes in the Great Salt Lake Basins study unit. The predominant contaminants that affect the use of streams by aquatic life are nutrients and metals. Point and nonpoint sources of contamination, including leachates from mining and mill tailings, urban activities, industrial activities, and wastewater from storm sewers and treatment plants have had detrimental effects on the ground- and surface-water resources of the Jordan River basin. Irrigation is the primary use of surface water and public supply is the primary use of ground water in the study unit.

Physiography, lithology, and land-use classifications were used to develop an environmental stratification diagram for designing data-collection activities for surface water. Ten basic-fixed sites for monitoring surface-water quality were selected on the major streams to be sampled during a 2-year period. The basic-fixed sites also are categorized as either indicators of water quality for a particular land use or integrators of water quality from many land uses in differing basin or environmental settings. Seven indicator sites are located on streams where a primary land use is represented in the upstream drainage. Integrator sites are located near the mouths of the Bear, Weber, and Jordan Rivers and receive runoff from about 95 percent of the study area.

Bed sediment and tissue (from fish and other aquatic animals) have been sampled to determine the occurrence of trace elements and hydrophobic organic contaminants in streams. Sites for the bed-sediment and tissue sampling include nine basic-fixed sites and three additional sites and were sampled during August and September 1998. A spatial distribution survey was designed on the basis of these findings. The spatial distribution survey provides more complete geographic coverage through larger areal sampling and improved resolution in priority areas.

Ecological studies, which included sampling of fish, macroinvertebrate, and algae communities, and a habitat survey were conducted at the ten fixed sites. Four sites were selected for sampling in multiple years and 3 of these sites also were selected for multiplereach sampling to assess within-stream variability of biological communities.

Study-unit surveys were designed to characterize the quality of water in the basin-fill aquifers.

Environmental stratification for ground-water systems in the Great Salt Lake Basins study unit was determined from physiography, lithology, and land use. The ground water in each of the stratified categories was divided into aquifers that occur in basin- and valley-fill deposits and water from consolidated rocks. The deeper unconfined and confined basin-fill aquifers provide most of the ground water used for drinking water and irrigation. Because of their importance as a water source and susceptibility to contamination, these subunits were selected to be examined during the study-unit surveys. During 1998, two study-unit surveys were conducted and each survey consisted of sampling about 30 wells randomly distributed within the subunit that had common characteristics.

Land-use studies were conducted in the study unit to assess the quality of recently recharged ground water associated with a predominantly urban land-use setting. The shallow ground-water aquifer underlying areas recently developed for residential and commercial use in the secondary recharge areas of Salt Lake Valley and the deeper aquifers used for public supply in the valley were studied. Water from about 30 wells was sampled for each of the land-use surveys.

The deeper unconfined aquifer and part of the confined basin-fill aquifer corresponds to the primary and secondary recharge areas delineated for Salt Lake Valley. Information is needed to determine if recently recharged water is reaching the deeper aquifers used for public supply, and if and where man-made compounds are present in the deeper ground water of the valley.

Sediment cores have been studied as part of the Great Salt Lake Basins NAWQA study and as part of the Western Lake Catchment (LACS) study within the USGS Global Change Program. Analysis of cores from the Wasatch Front will help reconstruct a history of contaminant flux from runoff and atmospheric 
deposition during the past several decades of urban and industrial growth. Red Butte Reservoir is representative of background levels of atmospheric deposition near urban areas because of its long history of protected land use in the watershed. Cores from Bear Lake will provide information on possible contaminants that may have entered Bear Lake from the upstream Bear River drainage or from tributaries of the lake.

\section{REFERENCES}

American Fisheries Society, 1991, Common and scientific names of fishes from the United States and Canada, 5th edition: American Fisheries Society Special Publication 20, Bethesda, MD., 183 p.

Anderson, M.A., 1963, A study of the productivity of macro-invertebrates and periphyton in the Smith and Morehouse Creek, Summit County, Utah: Salt Lake City, University of Utah, M.S. thesis, 72 p.

Anderson, J.R., Hardy, E.E., Roach, J.T., and Witmer, R.E., 1976, A land use and land cover classification system for use with remote sensor data: U.S. Geological Survey Professional Paper 964, 28 p.

Anderson, P.B., Susong, D.D., Wold, S.R., Heilweil, V.M., and Baskin, R.L., 1994, Hydrogeology of recharge areas and water quality of the principal aquifers along the Wasatch Front and adjacent areas, Utah: U.S. Geological Survey Water-Resources Investigations Report 93-4221, 74 p.

Arnow, T., 1984, Water-level and water-quality changes in Great Salt Lake, Utah, 1847-1983: U.S. Geological Survey Circular 913, 22 p.

Bjorklund, L.J., and McGreevy, L.J., 1971, Ground-water resources of Cache Valley, Utah and Idaho: Utah Department of Natural Resources Technical Publication No. 36, 72 p.

1974, Ground-water resources of the lower Bear River drainage basin, Box Elder County, Utah: Utah Department of Natural Resources Technical Publication No. 44, 65 p.

Bolke, E.L., and Waddell, K.M., 1972, Ground-water conditions in the East Shore area, Box Elder, Davis, and Weber Counties, Utah, 1960-69: Utah Department of Natural Resources Technical Publication No. 35, $59 \mathrm{p}$.

Brooks, L.E., and Stolp, B.J., 1995, Hydrology and simulation of ground-water flow in southern Utah and Goshen Valleys, Utah: Utah Department of Natural Resources Technical Publication No. 111, 96 p.

Burden, C.B., and others, 2001, Ground-water conditions in Utah, spring of 2001: Utah Division of Water Resources Cooperative Investigations Report No. 41, $120 \mathrm{p}$.
CH2M Hill, 1992, Jordan River Stability Study: Report submitted to Salt Lake County, variously paged.

Clark, D.W., and Appel, C.L., 1985, Ground-water resources of northern Utah Valley, Utah: Utah Department of Natural Resources Technical Publication No. 80, 115 p.

Clark, D.W., Appel, C.L., Lambert, P.M., and Puryear, R.L., 1990, Ground-water resources and simulated effects of withdrawals in the East Shore area of Great Salt Lake, Utah: Utah Department of Natural Resources Technical Publication No. 93, $150 \mathrm{p}$.

Cordova, R.M., 1970, Ground-water conditions in southern Utah Valley and Goshen Valley, Utah: Utah Department of Natural Resources Technical Publication No. 28, 79 p.

Cordova, R.M., and Subitzky, S., 1965, Ground water in northern Utah Valley, Utah: A Progress Report for the Period 1948-63: Utah State Engineer Technical Publication 11, $44 \mathrm{p}$.

Crist, Larry, and Holden, Paul, 1991, Preliminary annual report - 1990, fishery investigations of the lower Jordan River: BIO/WEST Inc., Logan, Utah, submitted to Central Valley Water Reclamation Board, Salt Lake City, Utah, 21 p.

Dover, J.H., 1987, Geologic map of the Mount Naomi roadless area, Cache County, Utah, and Franklin County, Idaho: Department of the Interior, U.S. Geological Survey, scale 1:100,000.

Duff, D.A., ed., 1996, Conservation assessment for inland cutthroat trout status and distribution: U.S. Department of Agriculture, Forest Service, Intermountain Region, Ogden, Utah, $120 \mathrm{p}$.

EDAW Inc., 1979, Jordan River Basin, Utah, Environmental Inventory: Prepared for U.S. Army Corps of Engineers, Sacramento, Calif., District, Contract DACW05-79-D0017, $62 \mathrm{p}$.

Environmental Dynamics, 1975, An environmental evaluation of the Utah Lake-Jordan River basin, final report: Submitted to National Commission on Water Quality WQ5AC071, Los Angeles, Calif.

Fenneman, N.M., 1931, Physiography of the western United States: New York, McGraw-Hill, 534 p.

Gaufin, A.R., 1959, Production of bottom fauna in the Provo River, Utah: Iowa State College Journal of Science, v. 33, no. 3, p. 395-419.

Gilbert, G.K., 1890, Lake Bonneville: U.S. Geological Survey Monograph 1, 438 p.

Gilliom, R.J., Alley, W.M., and Gurtz, M.E., 1995, Design of the National Water-Quality Assessment Program-Occurrence and distribution of water-quality conditions: U.S. Geological Survey Circular 1113, 33 p.

Halpin, M.A., 1987, Jordan river wetlands vegetation evaluation: Utah Division of Wildlife Resources, $40 \mathrm{p}$. 
Hely, A.G., Mower, R.W., and Harr, C.A., 1971, Water resources of Salt Lake County, Utah: Utah Department of Natural Resources Technical Publication No. 31, $244 \mathrm{p}$.

Herbert, L.R., Tibbetts, J.R., Wilberg, D.W., and Allen, D.V., 1998, Water resources data for Utah: U.S. Geological Survey Water-Data Report UT-97-1.

Hinshaw, R.N., 1967, The pollutional degradation of the Jordan River as shown by aquatic invertebrates: Salt Lake City, University of Utah, M.S. thesis, $121 \mathrm{p}$.

Hitt, K.J., 1994a, Refining 1970s land-use data with 1990 population data to indicate new residential development: U.S. Geological Survey Water-Resources Investigations Report 94-4250, 15 p.

1994b, Digital map file of 1990 Census block group boundaries for the United States processed from Bureau of the Census 1990 TIGER/Line files: Washington, D.C., 1:100,000 scale, digital data.

Holden, P.B., Zucker, S.J., Abate, P.D., and Valdez, R.A., 1996, Assessment of the effects of fish stocking in the State of Utah past, present, and future: Prepared by BIO/WEST, Inc. for the Utah Division of Wildlife Resources, Logan, Utah, 104 p.

Hunt, C.B., Varnes, H.D., and Thomas, H.E., 1953, Lake Bonneville: Geology of northern Utah Valley, Utah: U.S. Geological Survey Professional Paper 257-A, p. 199.

Jensen, S.F., 1991, Wasatch watershed monitoring network, 1990 season: Salt Lake City-County Health Department, Bureau of Water Quality and Hazardous Waste, variously paged.

Johnson, B.R., and Raines, G.L., 1995, Digital map of major bedrock lithologic units for the Pacific Northwest: a contribution to the Interior Columbia River Basin Ecosystem Management Project: U.S. Geological Survey Open-File Report 95-680, digital map.

Kariya, K.A., Roark, D.M., and Hanson, K.M., 1994, Hydrology of Cache Valley, Cache County, Utah, and adjacent part of Idaho, with emphasis on simulation of ground-water flow: Utah Department of Natural Resources Technical Publication No. 108, 120 p.

Lambert, P.M., 1995, Numerical simulation of ground-water flow in basin-fill material in Salt Lake Valley, Utah: Utah Department of Natural Resources Technical Publication No. 110-B, 58 p.

Leahy, P.P., Rosenshein, J.S., and Knopman, D.S., 1990, Implementation plan for the National Water-Quality Assessment Program: U.S. Geological Survey OpenFile Report 90-174, 10 p.

Leopold, L.B., Wolman, M.G., and Miller, J.P., 1964, Fluvial processes in geomorphology: New York, Dover Publications, $522 \mathrm{p}$.
Multi-resolution Land-Cover Characteristics Consortium, 1994, Multi-resolution land characteristics: U.S. Geological Survey, Sioux Falls, South Dakota, USA, satellite images.

Omernik, J.M., 1987, Ecoregions of the conterminous United States, Map Supplement: Annals of the Association of American Geographers 77(1), p. 118125.

Osborn, T.G., 1981, Stream insect production as a function of alkalinity and detritus processing: Logan, Utah, Utah State University, Ph.D. dissertation, 182 p.

Perkins, M.J., Lentsch, L.D., and Mizzi, J., 1997, Conservation agreement and strategy for Least chub, Iotichthys phlegethontis: Utah Division of Wildlife Resources and U.S. Fish and Wildlife Service, Salt Lake City, Utah, 34 p.

Sigler, W.F., and Miller, R.R., 1963, Fishes of Utah, Utah State Department of Fish and Game, Salt Lake City, Utah, 203 p.

Sigler, W.F., and Sigler, J.W., 1996, Fishes of Utah, a natural history: University of Utah Press, Salt Lake City, Utah, $375 \mathrm{p}$.

Solomon, D.K., and Cook, P.G., 2000, ${ }^{3} \mathrm{H}$ and ${ }^{3} \mathrm{He}$ in Cook, P.G., and Herczeg, A.L., eds., Environmental Tracers in Subsurface Hydrology: Boston, Mass., Kluwer Academic Publishers, 529 p.

Stevenson, R.J., Bothwell, M.L., and Lowe, R.L., eds., 1996, Algal ecology: San Diego, Calif., Academic Press, 758 p.

Thiros, S.A., 1995, Chemical composition of ground water, hydrologic properties of basin-fill material, and groundwater movement in Salt Lake Valley, Utah: Utah Department of Natural Resources Technical Publication No. 110-A, 59 p.

U.S. Department of Agriculture, 1972, Soil survey of Utah County, Utah, central part: Soil Conservation Service, 161 p., 21 pl.

1974, Soil survey of Cache Valley area, Utah, parts of Cache and Box Elder Counties: Soil Conservation Service, 203 p., 41 pl.

1994, State soil survey geographic data base (STATSGO): Soil Conservation Service National Cooperative Soil Survey, digital data.

1998, Parameter-elevation Regressions on Independent Slopes Model (PRISM)- derived precipitation contours, 1961-90: Natural Resource Conservation Service, National Water and Climate Center, Portland, OR.

U.S. Department of Commerce, 1992, Monthly normals of temperature, precipitation, and heating and cooling degree days, 1961-90, Utah, Wyoming, and Idaho, No. 81. 
U.S. Environmental Protection Agency, 1973, Jordan River study, Utah, June-August 1972: Report S\&A/TSB-16, Technical Support Branch, Surveillance and Analysis Division, Region 8, Denver, Colo., 67 p.

U.S. Fish and Wildlife Service, 1995, June sucker (Chasmistes liorus) recovery plan: Salt Lake City, Utah, $55 \mathrm{p}$.

U.S. Geological Survey, 1970, Surface-water supply of the United States 1961-65, Part 10, The Great Basin: U.S. Geological Survey Water-Supply Paper 1927. 1995, Aggregate water-use data system (AWUDS): U.S. Geological Survey AWUDS database, 1995. 1996, Utah GAP analysis: National Biological Service in collaboration with Utah State University, Logan, Utah, digital data.

Utah Department of Natural Resources, 1992, Utah State Water Plan-Bear River Basin: Division of Water Resources, Salt Lake City, Utah.

1995, Water-related land use inventories: Division of Water Rights, Salt Lake City, Utah, digital data, 1:24,000 scale, various source years. 1996, Water quality assessment report to Congress:

Division of Water Quality, Salt Lake City, Utah, 153 p. -1997a, Utah State Water Plan_-Jordan River basin: Division of Water Resources, Salt Lake City, Utah. 1997b, Utah State Water Plan_Utah Lake basin: Division of Water Resources, Salt Lake City, Utah. 1997c, Utah State Water Plan-Weber River basin: Division of Water Resources, Salt Lake City, Utah.
Utah Division of Wildlife Resources, 1996, Draft conservation agreement and strategy for Bonneville cutthroat trout (Oncorynchus clarki utah) in the State of Utah: Salt Lake City, Utah, 75 p.

Utah Governor's Office of Planning and Budget, 1999, Economic and demographic projections - 2000 Baseline: Salt Lake City, Utah.

Waddell, K.M., and Barton, J.D., 1980, Estimated inflow and evaporation for Great Salt Lake, Utah, 1931-76, with revised model for evaluating the effects of dikes on the water and salt balance of the lake: Utah Department of Natural Resources, Division of Water Resources Cooperative Investigation Report Number 20, 57 p.

Waddell, K.M., Seiler, R.L., Santini, Melissa, and Solomon, D.K., 1987a, Ground-water conditions in Salt Lake Valley, Utah, 1969-83, and predicted effects of increased withdrawals from wells: Utah Department of Natural Resources Technical Publication No. 87, 69 p.

Waddell, K.M., Seiler, R.L., and Solomon, D.K., 1987b, Chemical quality of ground water in Salt Lake Valley, Utah, 1969-85: Utah Department of Natural Resources Technical Publication No. 89, 44 p.

Way, T.G., 1980, Fishery potential of the Jordan River as affected by wastewater treatment alternatives: Salt Lake City, University of Utah, M.S. thesis, 135 p.

Wilson, L., Olsen, M.E., Hutchings, T.B., Southard, A.R., Erickson, A.J., 1975, Soils of Utah: Agricultural Experiment Stations, Bulletin 492, Logan, Utah, Utah State University, 94 p. 


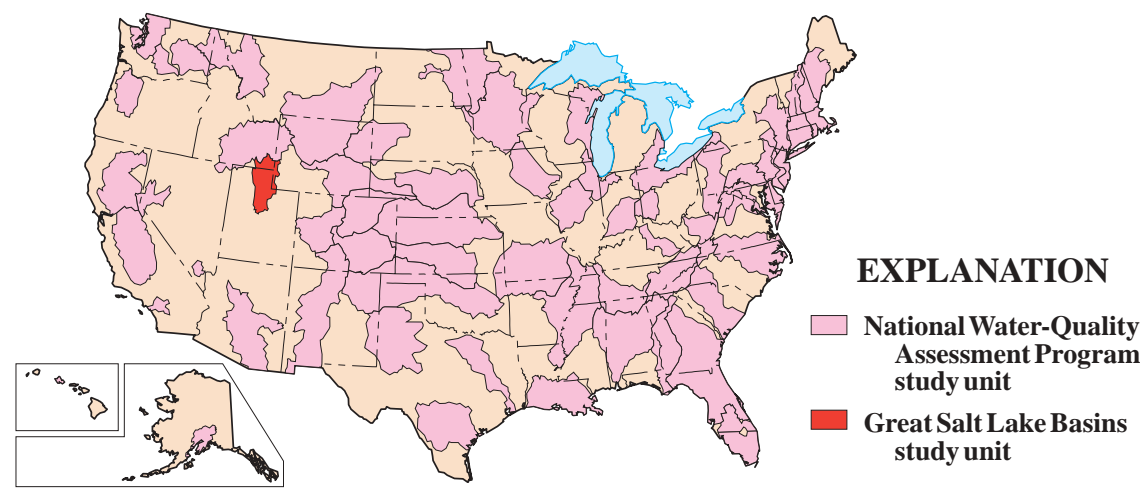

